Spring 2006

\title{
Toward a Unified Test of Personal Jurisdiction in an Era of Widely Diffused Wrongs: The Relevance of Purpose and Effects
}

\author{
C. Douglas Floyd \\ Brigham Young University, floydd@lawgate.byu.edu \\ Shima Baradaran-Robison \\ Ninth Circuit Court of Appeals
}

Follow this and additional works at: https://www.repository.law.indiana.edu/ilj

Part of the Courts Commons, and the Internet Law Commons

\section{Recommended Citation}

Floyd, C. Douglas and Baradaran-Robison, Shima (2006) "Toward a Unified Test of Personal Jurisdiction in an Era of Widely Diffused Wrongs: The Relevance of Purpose and Effects," Indiana Law Journal: Vol. 81 : Iss. 2 , Article 4.

Available at: https://www.repository.law.indiana.edu/ilj/vol81/iss2/4

This Article is brought to you for free and open access by the Law School Journals at Digital Repository @ Maurer Law. It has been accepted for inclusion in Indiana Law Journal by an authorized editor of Digital Repository @ Maurer Law. For more information, please contact rvaughan@indiana.edu.

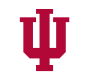

JEROME HALL LAW LIBRARY

INDIANA UNIVERSITY

Maurer School of Law
Blooming ton 


\title{
Toward a Unified Test of Personal Jurisdiction in an Era of Widely Diffused Wrongs: The Relevance of Purpose and Effects
}

\author{
C. Douglas Floyd and Shima Baradaran-Robison **
}

INTRODUCTION .602

I. THE Evolution OF DIFFERING, CONTEXT-SPECIFIC TESTS

FOR PERSONAL JURISDICTION .605

A. The Purposeful Availment Test, Developed in the Context of Interstate Business Activities .605

B. The Calder Effects Test, Developed in the Context of Intentional Torts Having Interstate Effects.

C. The Zippo Sliding Scale Test,Developed in the Context of Internet Activities

II. CONFUSION REGARDING THE APPLICABILITY, MEANING, AND

RELATIONSHIP OF THE VARIOUS CONTEXT-SPECIFIC TESTS FOR PERSONAL JURISDICTION

A. Which Test Applies? ....................................................................614

B. What Do the Various Personal Jurisdiction Tests Mean?

C. What is the Relationship Among the Various Jurisdictional Tests? ...622

III. THE CASE FOR A UNIFIED AND OBJECTIVE TEST FOR PERSONAL JURISDICTION BASED ON THE GEOGRAPHICALLY SPECIFIC SCOPE THAT THE DEFENDANT SHOULD ASCRIBE TO THE IMPACT OF ITS ACTIVITIES

A. The Case for a Unified Approach to Issues of Personal Jurisdiction 626

B. The Case for Rejecting Subjective Purpose or Intent to Cause Harm in the Forum as a Determinant of Personal Jurisdiction

C. The Case for Basing Personal Jurisdiction on Defendant's Activity Giving Rise to the Action Which the Defendant Knows or Should Know Is Substantially Certain to Have Its Wrongful Impact in the Forum State

CONCLUSION .666

* Professor of Law, J. Reuben Clark Law School, Brigham Young University. B.S. 1964 Massachusetts Institute of Technology; J.D. 1967 Stanford University. We wish to express our appreciation to Professor James R. Rasband for his helpful comments on an earlier draft of this article.

** Law Clerk to the Honorable Jay S. Bybee, Ninth Circuit Court of Appeals, 2004-05. B.S. 2001 Brigham Young University; J.D. 2004 J. Reuben Clark Law School. 


\section{INTRODUCTION}

The prevalence in modern society of widely diffused wrongs committed by the transmission of information, whether by traditional means or over the Internet, ${ }^{1}$ has placed increasing strain on traditional concepts of personal jurisdiction. While the Supreme Court has stayed above the fray, lower federal and state courts struggle to apply older formulations in new contexts. The problems are varied and difficult, leading to closely divided opinions and debatable results and raising new issues of appropriate limits on the sovereign power of the states and fairness to the parties.

Consider, for example, the decision of the California Supreme Court in Pavlovich $v$. Superior Court, ${ }^{2}$ in which the court divided four-to-three on the question of whether a Texas Web site operator who had posted software designed to defeat the plaintiff's technology for encrypting copyrighted motion pictures was subject to personal jurisdiction in California where the motion picture, computer, and DVD industries were centered. In rejecting jurisdiction, the majority focused on the fact that the defendant did not know that the particular plaintiff, a licensing entity created by the motion picture and DVD industries, was located there. ${ }^{3}$ The dissenters thought it sufficient that the defendant was on notice that its conduct would harm the motion picture and DVD industries centered in California. ${ }^{4}$ Or consider the Ninth Circuit's recent, divided opinion in Yahoo! Inc. v. La Ligue Contre Le Racisme et $L$ 'Antisemitsme, ${ }^{5}$ where the majority rejected jurisdiction in California in an action by a California Internet service provider seeking a declaration that a French court order requiring the plaintiff to block French citizens' access to Nazi material displayed on plaintiff's Web site violated the First Amendment. The dissenting judge would have upheld jurisdiction on the ground that the defendants knew that their conduct would have a "powerful and potentially devastating impact" on the plaintiff in California, requiring it to alter its servers there under pain of severe penalties. ${ }^{6}$

Courts confronting these and similarly difficult issues of personal jurisdiction in the context of actions for defamation, copyright infringement, unfair competition, and other wrongs having potentially widely dispersed effects have evidenced considerable confusion over what jurisdictional test should be applied in such cases and over the proper interpretation of those tests in new contexts with which they were not designed to deal. In particular, the courts have struggled with the meaning of the Supreme Court's "purposeful availment" test, originally developed in the context of contract and product liability disputes arising from the conduct of interstate business, ${ }^{7}$ and of the

1. The harmful effects of such wrongs typically are intangible or financial rather than physical. Examples include defamation, copyright and trademark infringement, and unfair competition.

2. 58 P.3d 2 (Cal. 2002).

3. Id. at $11-12$.

4. Id. at 13, 20-25 (Baxter, J., dissenting).

5. 379 F.3d 1120 (9th Cir. 2004).

6. Id. at 1134 .

7. See, e.g., Burger King v. Rudzewicz, 471 U.S. 462 (1985); World-Wide Volkswagen Corp. v. Woodson, 444 U.S. 286 (1980). 
"effects" test developed by the Supreme Court in the context of intentionally tortious activity committed in one state but having effects in another. ${ }^{8}$ They also have evidenced uncertainty regarding the relationship between these two apparently distinct tests for personal jurisdiction. In the specific context of Internet activities, the courts sometimes have relied on new interpretations of one or the other of these established approaches to questions of personal jurisdiction, and sometimes have fashioned new tests not dependent upon either of them.

Most recent literature in this area has focused on whether the commission of wrongs by the transmission of information over the omnipresent Internet should give rise to unique tests for personal jurisdiction and, if so, what those tests should be. ${ }^{9}$ Our focus

8. See Calder v. Jones, 465 U.S. 783 (1984).

9. Some commentators have argued that current personal jurisdiction law is not suited to deal with the Internet. See William S. Byassee, Jurisdiction of Cyberspace: Applying Real World Precedent to the Virtual Community, 30 WAKE FOREST L. REV. 197 (1995); Martin H. Redish, Of New Wine and Old Bottles: Personal Jurisdiction, the Internet, and the Nature of Constitutional Evolution, 38 JURIMETRICS J. 575 (1998). Others contend that current jurisdictional doctrine can be adapted to deal with the Internet. See Allan R. Stein, The Unexceptional Problem of Jurisdiction in Cyberspace, 32 INT'L LAw. 1167 (1998); Mary Twitchell, Why We Keep Doing Business with Doing-Business Jurisdiction, 2001 U. CHI. LEGAL F. 171 (2001) (arguing that we should maintain our jurisdictional framework despite the problems brought by the Internet). The problem has generated considerable academic commentary. See, e.g., Patrick J. Borchers, Internet Libel: The Consequences of a Non-Rule Approach to Personal Jurisdiction, 98 Nw. U. L. REV. 473, 474, 492 (2004) (focusing on the confluence of Internet jurisdiction and libel jurisdiction and concluding that the consequence has been "inconsistency in result and uncertainty in application" and that the best solution would be state or federal legislation); Joseph S. Burns \& Richard A. Bales, Personal Jurisdiction and the Web, 3 ME. L. REv. 29, 31-32 (2001) (summarizing the "spider web" approach to personal jurisdiction over the Internet, where "the operator of a Web site is deemed to be jurisdictionally 'present' at every location from which her site is accessed" and the "highway approach, [under which] the operator of a Web site is jurisdictionally present in a foreign state only if the operator has somehow 'reached out' to a person or entity in the foreign state, such as by soliciting information from or selling a product over the Web to a person or entity in the foreign state"); Mark C. Dearing, Personal Jurisdiction and the Internet: Can the Traditional Principles and Landmark Cases Guide the Legal System into the 21st Century?, $4 \mathrm{~J}$. TECH. L. \& PoL'Y 819 (1999); Andrea M. Matwyshyn, Of Nodes and Power Laws: A Network Theory Approach to Internet Jurisdiction Through Data Privacy, 98 Nw. U. L. REV. 493, 494 (2004) (proposing a "Trusted Systems" approach to Internet personal jurisdiction issues that addresses the "flaws of previous Internet-specific jurisdictional frameworks" by providing "firmer grounding" in traditional jurisdiction doctrine and minimum contacts analysis "for the future evolution of jurisdiction precedent in cases involving alleged harms arising out of new media"); Wendy Perdue, Aliens, the Internet, and "Purposeful Availment": A Reassessment of Fifth Amendment Limits on Personal Jurisdiction, 98 Nw. U. L. REV. 455 (2004) (discussing the implications of current personal jurisdiction doctrine as it impacts sovereignty considerations); Richard Philip Rollo, The Morass of Internet Personal Jurisdiction: It Is Time for a Paradigm Shift, 51 FLA. L. REV. 667 (1999); Allan R. Stein, Personal Jurisdiction and the Internet: Seeing Due Process Through the Lens of Regulatory Precision, 98 Nw. U. L. REV. 411, 411-13 (2004) [hereinafter Stein, Regulatory Precision] (pointing out that although the Internet has increased the "quantity" of jurisdictional occurrences, "it has not created problems that are qualitatively more difficult" and arguing that personal jurisdiction in cases involving Internet activities 
is broader: do the problems that courts have experienced in dealing with issues of personal jurisdiction in new contexts require new and separate jurisdictional tests, or, in cases where jurisdiction is asserted in a forum remote from the defendant's residence or the place or wrongdoing, ${ }^{10}$ is there a unified test that should be applied in all jurisdictional arenas? In particular, has the Supreme Court appropriately articulated separate tests for personal jurisdiction in the context of interstate business activities having effects within the forum, on the one hand, and in the context of intentional torts committed in one state but having effects in another? Beyond this, what is the meaning and relationship of the different tests? Does the Burger King " purposeful availment test developed in the context of interstate business activities contemplate a subjective or an objective inquiry? What is the meaning of the express aiming or targeting concept adopted by the Supreme Court in the intentional tort context in Calder $v$. Jones? ${ }^{12}$ Is that test subjective or objective? Is it distinct from the purposeful availment test? And if the tests are related, what is the nature of that relationship? And finally, what is the relationship of either or both of these tests to the Zippo sliding scale test adopted in whole or in part by many courts to deal with cases arising from the conduct of Internet activities by the defendant? ${ }^{13}$

No commentator has yet reconciled the Zippo, Calder, and Burger King tests, adequately explained the relationship among them, or clearly described the context in which each test should apply. After exploring the confusion created by these various tests, we argue instead for a unified test for personal jurisdiction based on an objective evaluation of the defendant's activities with regard to the forum state. Our central conclusions are: (1) A unified approach to questions of personal jurisdiction should be applied to all cases in which jurisdiction is asserted in a forum remote from the defendant's residence or the place of wrongdoing, regardless of the particular subject

should be limited to cases in which the forum had a valid ex ante regulatory interest in the defendant's behavior); Leif Swedlow, Three Paradigms of Presence: A Solution for Personal Jurisdiction on the Internet, 22 OKLA. CITY U. L. REV. 337, 370-75 (1997) (describing the "spider web" approach to personal jurisdiction on the Internet); Ryan Yagura, Does Cyberspace Expand the Boundaries of Personal Jurisdiction?, 38 J. L. \& TECH. 301 (1998); Carly Henek, Note, Exercises of Personal Jurisdiction Based on Internet Web Sites, 15 ST. JOHN's J. LEGAL COMMENT. 139, 163 (2000) ("examining the level of interactivity and the commercial nature of the exchange of information that occurs through a Web site," which remains true to the "spirit of the minimum contacts test"); Katherine Neikirk, Note, Squeezing Cyberspace into International Shoe: When Should Courts Exercise Personal Jurisdiction over Noncommercial Online Speech? 45 VILl. L. REV. 353 (2000); Note, No Bad Puns: A Different Approach to the Problem of Personal Jurisdiction and the Internet, 116 HARV. L. REV. 1821, 1823 (2003) (arguing that taking a"strict proximate cause approach to the "relatedness prong" in personal jurisdiction analysis is the best way to tackle personal jurisdiction on the Internet).

10. The approach suggested in this Article establishes a sufficient but not a necessary test for personal jurisdiction. Traditional jurisdiction would continue to be proper in the state of defendant's domicile, state of incorporation, or principal place of business, because the defendant is clearly on notice that it may be subject to suit there. See generally JACK H. Friedenthal, Mary Kay Kane \& ARTHUR R. Miller, Civil Procedure \$ \$ 3.3-4, 3.6-7 (4th ed. 2005). Similarly, the approach of the Article also suggests that jurisdiction would be proper in a state where the defendant's wrongful acts giving rise to remote effects were committed.

11. Burger King, 471 U.S. at 473-75.

12. Calder, 465 U.S. at 789.

13. Zippo Mfg. Co. v. Zippo Dot Com, Inc., 952 F. Supp. 1119 (W.D. Pa. 1997). 
matter of the action, the legal theories that it raises, or the means by which the allegedly wrongful conduct of the defendant has been committed. (2) The factors informing such an approach must be sufficiently flexible to take account of the wide array of differing contexts in which issues of personal jurisdiction are presented, and, in particular, to take account of the unique characteristics of the Internet that have increasingly troubled the courts in recent years. (3) The Supreme Court's apparent importation of notions of a defendant's purpose or its intent to target the forum state is flawed and has created more problems than it has resolved in the context of modern actions involving informational torts. (4) Questions of personal jurisdiction should turn on objective (rather than subjective) factors that have primary reference to whether the defendant objectively should be on notice that it has caused the effects giving rise to the action in the particular forum state. If such notice does exist, the court should further inquire whether the intervening acts of third parties should relieve the defendant of geographic responsibility for those effects and whether the balance of the interests of the defendant, the plaintiff, and the forum state makes it fundamentally unfair to subject the defendant to suit there.

\section{THE EVOLUTION OF DIFFERING, CONTEXT-SPECIFIC TESTS FOR PERSONAL JURISDICTION}

The difficult jurisdictional questions posed by cases such as Pavlovich and Yahoo! is compounded by the potential applicability of differing jurisdictional tests that might be invoked to resolve them. Although the leading cases articulating these apparently distinct tests are familiar, a brief review provides an essential foundation for further analysis.

\section{A. The Purposeful Availment Test, Developed in the Context of Interstate Business Activities}

The Supreme Court's foundational decision establishing the minimum contacts test for personal jurisdiction in the context of interstate business activities made no reference to any question of the defendant's intent to cause injury in the forum. In holding that the defendant shoe company was subject to personal jurisdiction in a Washington action to collect unemployment compensation contributions, the Supreme Court, in International Shoe v. Washington, rejected a test based on fictional presence in favor of one inquiring whether the defendant has "certain minimum contacts with [the state] such that the maintenance of the suit does not offend "traditional notions of fair play and substantial justice."'14 The Court reviewed cases in which jurisdiction previously had been rejected and sustained, not in terms of the purpose or intent of the defendant, but rather in terms of the nature and quantum of the defendant's activities with respect to the forum state. ${ }^{15}$

14. Int'I Shoe Co. v. Washington, 326 U.S. 310, 316 (1945) (quoting Milliken v. Meyer, 311 U.S. 457,463 (1940)).

15. The Court noted that personal jurisdiction "has never been doubted when the activities of the corporation there have not only been continuous and systematic, but also give rise to the liabilities sued on," and that, conversely, "the causal presence of the corporate agent or even his conduct of single or isolated items of activities in a state in the corporation's behalf are not 
The Supreme Court's focus on purposeful conduct of the defendant emerged in Hanson v. Denckla. ${ }^{16}$ In rejecting the jurisdiction of the Florida courts over a Delaware trust company in an action challenging a Florida decedent's appointment of property of which the Delaware company was trustee, the Court emphasized the fact that the trust settlor had moved from Pennsylvania to Florida after the trust was created, and that the trust company had solicited and conducted no business in Florida other than routine correspondence with the settlor. ${ }^{17}$ The trust company had not purposefully undertaken to conduct business in the state of Florida, but rather was connected with the state only by virtue of the fact that the other party to the agreement unilaterally had moved to the state of Florida after the contractual relationship at issue had been established.

In World-Wide Volkswagen Corp. v. Woodson, ${ }^{18}$ the Court addressed the scope of personal jurisdiction in actions asserting product liability claims against business entities. In holding that the New York wholesaler and retailer of an automobile involved in an accident while it was being driven by the purchasers through Oklahoma were not subject to personal jurisdiction there, the Court again emphasized that the defendants had not undertaken to conduct any business in Oklahoma, and that their only connection with the state arose as a result of the "unilateral activity" of the purchasers driving the car there. ${ }^{19}$ The Court elaborated on Shoe's minimum contacts test by stating that it performed "two related, but distinguishable, functions." was to protect the defendant from the burden of litigating in a distant or inconvenient forum. The second was to ensure that the states do not "reach out beyond the limits imposed on them by their status as coequal sovereigns in a federal system."21 Citing

enough to subject it to suit on causes of action unconnected with the activities there." Id. at 317 . The Court went on to note that in some cases of "continuous activity of some sorts within a state," jurisdiction on "unrelated" causes of action had been rejected, but in others "the continuous corporate operations within a state were thought so substantial and of such a nature as to justify suit against it on causes of action arising from dealings entirely distinct from those activities." Id. at 318. Finally, although some "single or occasional acts" of a corporate agent within a state had not been thought sufficient to confer personal jurisdiction to enforce liabilities arising from those acts, others, "because of their nature and quality and the circumstances of their commission, may be deemed sufficient to render the corporation liable to suit." Id. The test was said not to be "mechanical or quantitative" or whether the corporation's activities in a state were "a little more or a little less." Id. at 319. Rather "whether due process is satisfied must depend ... upon the quality and nature of the activity in relation to the fair and orderly administration of the laws which it was the purpose of the due process clause to insure. That clause does not contemplate that a state may make binding a judgment in personam against an individual or corporate defendant with which the state has no contacts, ties or relations." Id.

16. 357 U.S. 235 (1958).

17. The Court held that the "unilateral activity of those who claim some relationship with a nonresident defendant" could not satisfy the requirement of minimum contacts. $I d$. at 253 .

The application of that rule will vary with the quality and nature of the defendant's activity, but it is essential in each case that there be some act by which the defendant purposefully avails itself of the privilege of conducting activities within the forum State, thus invoking the benefits and protections of its laws.

Id. (emphasis added).

18. 444 U.S. 286 (1980).

19. Id. at 298.

20. Id. at 291-92.

21. Id. The Court described the first requirement as one of "reasonableness" or "fairness," and indicated that in view of modern means of transportation and communication, it imposed a 
Hanson v. Denckla, the Court explained that the foreseeability that an automobile might be taken to Oklahoma was not relevant. Rather, the relevant foreseeability is the foreseeability "that the defendant's conduct and connection with the forum state are such that he should reasonably anticipate being haled into court there." 22 The Court concluded that this predictability requirement was satisfied where a corporation "purposefully avails itself of the privilege of conducting activities within the forum State," providing "clear notice that it is subject to suit there," and permitting it to alleviate the risk of litigation by procuring insurance or withdrawing from the state. ${ }^{23}$ But in Volkswagen, where there was no effort by defendants to serve the Oklahoma market, permitting the assertion of personal jurisdiction based on an "isolated occurrence" 24 arising from the "unilateral activity" of a third party went too far. ${ }^{25}$

The Court next relied on language of purpose in Burger King v. Rudzewicz, ${ }^{26}$ which involved an interstate contract dispute. Respondent had entered a franchise agreement with Burger King to operate a Burger King restaurant in Michigan. Burger King was a Florida corporation and the agreement provided that it should be governed by Florida law. Rudzewicz applied for and signed the agreement in Michigan, but negotiated directly with Burger King's Miami headquarters over certain provisions, and, later, when disputes under the agreement arose. Burger King accepted the agreement in Florida. $^{27}$

The Supreme Court sustained personal jurisdiction in Florida over Rudzewicz in Burger King's United States District Court action for past due rentals. The Court again emphasized that the Due Process Clause functions to ensure predictability that allows defendants to structure the scope of their business operations with assurance as to where they might be subject to suit. "Where a forum seeks to assert specific jurisdiction over an out-of-state defendant . . . this 'fair warning' requirement is satisfied if the defendant has 'purposefully directed' his activities at residents of the forum ...."29 The Court's focus was not on Rudzewicz's intent to cause injury in the

less stringent restriction on the scope of state court jurisdiction than it originally did. The fairness issue was to be evaluated taking into account the burden on the defendant, the interest of the plaintiff in obtaining relief, the forum state's interest in adjudicating the dispute, the judicial system's interest in the efficient resolution of controversies, and the interest of the affected states in furthering their substantive policies. In apparent reference to the second, "sovereignty" component of minimum contacts analysis, the Court indicated that even where the defendant "would suffer minimal or no inconvenience from being forced to litigate before the tribunals of another state," and even if the forum state has a strong interest in applying its law to the controversy and is the most convenient location for the litigation, it may sometimes lack jurisdiction as a result of territorial limits on the sovereignty of the states. Id. at 293-94.

22. Id. at 297 (emphasis added).

23. Id.

24. Id. at 295 .

25. Id. at 298 .

26. 471 U.S. 462 (1985).

27. Id. at $464-69$.

28. Id. at $471-72$.

29. Id. at 472 (quoting Keeton v. Hustler Magazine, Inc., 465 U.S. 770, 774 (1984)). Applying these principles to the contract dispute before it, and considering the negotiations leading to the formation of the contract, its terms, and the future consequences that were its intended objective, the Court sustained the exercise of personal jurisdiction over Rudzewicz on the ground that he had deliberately reached out to accept the benefits of doing business with a 
forum, but on the activities by which he voluntarily reached out to do business with a Florida corporation. Having done so, he was properly subjected to suit in Florida for misconduct in the course of the relationship that predictably caused injury there.

The Court's last decision invoking the concept of purposeful availment as a basis for personal jurisdiction in the context of interstate or international business activity was Asahi Metal Indus. Co. v. Superior Court. ${ }^{30}$ The defendant was a Japanese corporation that sold valve assemblies for tire tubes manufactured by a Taiwanese corporation and exported by it to the United States. A motorcycle tire incorporating one of the tubes containing an Asahi valve exploded, causing an accident in California. ${ }^{31}$ In considering personal jurisdiction over Asahi as a third-party defendant in the ensuing California product liability action, Justice O'Connor's plurality opinion phrased the issue as whether "mere awareness on the part of a foreign defendant that the components it manufactured, sold, and delivered outside the United States would reach the forum State in the stream of commerce constitutes 'minimum contacts' between the defendant and the forum State such that the exercise of jurisdiction 'does not offend traditional notions of fair play and substantial justice.",32

In an opinion joined by only three other members of the Court on this point, Justice O'Connor concluded that Asahi had not "purposefully established minimum contacts" with the forum as required by Burger King, and also relied on Hanson $v$. Denckla for the proposition that the defendant must "purposefully avail itself of the privilege of conducting activities within the forum State, thus invoking the benefits and protections of its laws." ${ }^{33}$ Reviewing a conflict of authority among both state and federal courts on whether a defendant's awareness that its goods would be swept into the forum in the stream of commerce was sufficient to satisfy these requirements, Justice O'Connor concluded that "something more" was required. ${ }^{34}$ The defendant must have engaged in some act "purposefully directed toward the forum state."35

Additional conduct of the defendant may indicate an intent or purpose to serve the market in the forum State, for example, designing the product for the market in the forum State, advertising in the forum State, establishing channels for providing regular advice to customers in the forum State, or marketing the product through a distributor who has agreed to serve as the sales agent in the forum State. But a defendant's awareness that the stream of commerce may or will sweep the product into the forum State does not convert the mere act of placing the product into the stream into an act purposefully directed toward the forum State. ${ }^{36}$

Florida corporation. Id. at 478-79. The contract contemplated wide ranging and continuing contacts with Burger King in Florida. Id. at 480. Rudzewicz's conduct had "caused foreseeable injuries" to the corporation in Florida, making the exercise of jurisdiction presumptively reasonable. Id.

30. 480 U.S. 102 (1987).

31. Id. at $105-06$.

32. Id. at 105 (quoting Int'l Shoe Co. v. Washington, 326 U.S. 310,316 (1945)).

33. Id. at $108-09$.

34. Id. at 111 .

35. Id. at 112 .

36. Id. (emphasis added). 
As this excerpt nicely illustrates, Justice O'Connor and three other justices insist on actions that connect a defendant to a forum that go beyond merely permitting a product to enter the stream of commerce.

Although eight Justices agreed that the exercise of personal jurisdiction in Asahi violated due process because it was unreasonable under the second prong of the Volkswagen-Burger King test, ${ }^{37}$ a majority of the Court did not concur with Justice O'Connor's analysis of the purposeful availment requirement. ${ }^{38} \mathrm{Justice}$ Brennan, in an opinion joined by three other Justices, concluded that deliberately placing a product in the stream of commerce with the awareness that it would find its way to the forum state was sufficient to satisfy the requirement that Asahi purposefully establish minimum contacts with California. ${ }^{39} \mathrm{He}$ reasoned:

The stream of commerce refers not to unpredictable currents or eddies, but to the regular and anticipated flow of products from manufacture to distribution to retail sale. As long as a participant in this process is aware that the final product is being marketed in the forum State, the possibility of a lawsuit there cannot come as a surprise . . . . A defendant who has placed goods in the stream of commerce benefits economically from the retail sale of the final product in the forum State, and indirectly benefits from the State's laws that regulate and facilitate commercial activity. ${ }^{40}$

In such circumstances, the defendant reasonably could anticipate litigation in the forum state and could take steps to insure or avoid the sale of its product in the state. ${ }^{41}$

In sum, International Shoe, Hanson, Volkswagen, Burger King, and Asahi, all were suits arising from the conduct of interstate or international business in which the court restricted the scope of personal jurisdiction to forums in which the defendant directly or indirectly conducted its business, creating the harm or risk of harm in the forum that gave rise to the plaintiff's action. In none of the cases did a majority of the Court rely on the purpose or intent of the defendant to cause injury in the forum or to injure the

37. Id. at 114; id. at 121 (Stevens, J., concurring in part and in the judgment).

38. Id. at 115 (majority opinion); id. at 122 (Stevens, J., concurring in part and in the judgment).

39. Id. at 121 .

40. Id. at 117 (Brennan, J., concurring in part and in the judgment).

41. Justice Stevens concurred specially without adopting the reasoning of either Justice O'Connor or Justice Brennan on this point, finding it unnecessary to the decision in view of the Court's broad agreement that the exercise of jurisdiction over a foreign defendant in the circumstances of Asahi would be unreasonable. However, he indicated that the proper resolution of the "purposeful availment" requirement in this context should turn primarily on quantitative factors, finding no "unwavering line ... between 'mere awareness' that a component will find its way into the forum State and 'purposeful availment' of the forum's market." Id. at 122 (Stevens, J., concurring in part and in the judgment). "Whether or not [Asahi's] conduct rises to the level of purposeful availment requires a constitutional determination that is affected by the volume, the value, and the hazardous character of the components. In most circumstances I would be inclined to conclude that a regular course of dealing that results in deliveries of over 100,000 units annually over a period of several years would constitute 'purposeful availment' even though the item delivered to the forum State was a standard product marketed throughout the world." Id. 
plaintiff there. Rather, the Court relied on the nature and quantum of the defendant's business activities in the forum and the defendant's objective awareness that a decision to conduct interstate business operations required it to accept the consequences of those operations in other states.

\section{B. The Calder Effects Test, Developed in the Context of Intentional Torts Having Interstate Effects}

Where the conduct of an intentional tortfeasor in one state foreseeably has caused injury in another, the Supreme Court has adopted an apparently distinct test for personal jurisdiction. In contrast to the interstate business cases, however, the Court's approach to such cases has focused centrally on the defendant's purpose or intent to injure the plaintiff in the forum state.

Keeton v. Hustler Magazine, Inc. ${ }^{42}$ straddles the boundary between cases involving intentional torts committed outside the forum state causing injury within and torts and other wrongful conduct arising from the conduct of interstate business operations in the forum. In Keeton, the Court considered whether New Hampshire had exceeded constitutional limits by asserting jurisdiction in a defamation action by a New York resident against an Ohio corporation that published a nationally circulated magazine in which the allegedly defamatory article had appeared. The Court concluded that "[r]espondent's regular circulation of magazines in the forum State is sufficient to support an assertion of jurisdiction in a libel action based on the contents of the magazine., ${ }^{, 43}$ The circulation of the magazine within the state was purposefully directed at New Hampshire, and was not "random, isolated, or fortuitous." 44 In sum, "[w]here, as in this case, respondent Hustler Magazine, Inc., has continuously and deliberately exploited the New Hampshire market, it must reasonably anticipate being haled into court there in a libel action based on the contents of its magazine. ${ }^{, 45}$ Although Keeton involved an intentional tort, the Supreme Court's analysis still fell within the main line of its previous interstate business decisions. Keeton restricted the scope of personal jurisdiction in suits arising from the conduct of an interstate business to forums in which the defendant directly or indirectly conducted its business, without examining where the defendant had targeted its activities.

The Court first directly confronted the scope of personal jurisdiction in actions based on intentional torts not arising from the defendant's conduct of interstate business in Calder v. Jones. ${ }^{46}$ Superficially, the case resembled Keeton. The plaintiff, a California resident, commenced a libel action in California state court based on an article published by the National Enquirer and circulated in California. In addition to the Enquirer and its local distributing company, the defendants included the author and editor of the article, who resided and worked in Florida ${ }^{47}$ The issue before the Court was whether the assertion of personal jurisdiction over the individual defendants violated due process. The case differed from Keeton in the important respect that it

42. 465 U.S. 770 (1984).

43. Id. at $773-74$.

44. Id. at 774 (quoting the opinion of the District Court).

45. Id. at 781 .

46. 465 U.S. 783 (1984).

47. Id. at $784-86$. 
involved defendants who did not themselves seek to sell products or services in California. $^{48}$

In sustaining the exercise of personal jurisdiction, the Supreme Court endorsed an "effects" test that has proved difficult to interpret in subsequent cases.

The allegedly libelous story concerned the California activities of a California resident. It impugned the professionalism of an entertainer whose television career was centered in California. The article was drawn from California sources, and the brunt of the harm, in terms both of respondent's emotional distress and the injury to her professional reputation, was suffered in California. In sum, California is the focal point both of the story and of the harm suffered. Jurisdiction over petitioners is therefore proper in California based on the "effects" of their Florida conduct in California. ${ }^{49}$

Had the Court stopped there, the opinion would have provided little support for importing some sort of desire or motivation to cause injury in the forum or to target the plaintiff into personal jurisdiction analysis. The focus was on the harm that defendants had caused with full awareness that the effects of their conduct would be felt in California.

However, petitioners contended that they should not be subjected to personal jurisdiction in California based merely on the foreseeability that their conduct would cause harm there because they had no control over the business operations of the Enquirer or the circulation of the paper. The Court responded with the "express aiming" language that has caused so much difficulty in subsequent decisions. ${ }^{50}$

[P] etitioners are not charged with mere untargeted negligence. Rather, their intentional, and allegedly tortious, actions were expressly aimed at California. Petitioner South wrote and petitioner Calder edited an article that they knew would have a potentially devastating impact upon respondent. And they knew that the brunt of that injury would be felt by respondent in the State in which she lives and works and in which the National Enquirer has its largest circulation. Under the circumstances, petitioners must 'reasonably anticipate being haled into court there' to answer for the truth of the statements made in their article $\ldots{ }^{51}$

The Court added that "[a]n individual injured in California need not go to Florida to seek redress from persons who, though remaining in Florida, knowingly cause the

48. The author was a reporter employed by the Enquirer who was a resident of Florida. The record showed that he traveled to California frequently on business, relied on phone calls to California to gather information for the article, and visited the State on at least one occasion in connection with the article. However, the Supreme Court expressly declined to rely on the visit and phone calls to sustain the exercise of personal jurisdiction. Id. at 787 n.6. The editor of the allegedly defamatory article also lived and worked in Florida and had visited California only twice on a pleasure trip and to testify in an unconnected trial. Id. at 786.

49. Id. at 788-89 (emphasis added) (citing World-Wide Volkswagen Corp. v. Woodson, 444 U.S. 286, 297-98 (1980)) .

50. See infra Part II.B.

51. Id. at 789-90. (emphasis added) (italics added) (quoting World-Wide Volkswagen Corp., 444 U.S. at 297). 
injury in California. ... In this case, petitioners are primary participants in an alleged wrongdoing intentionally directed at a California resident, and jurisdiction over them is proper on that basis." 52

Two important questions arise from Calder's express aiming and intent language. First, how should intent and express aiming be interpreted? As the law of torts demonstrates, intent is an elusive concept. Definitions of intent range from deliberate indifference, to knowledge to a substantial certainty, to subjective intent or motivation to harm the plaintiff. ${ }^{53}$ Most fairly read, the Court's opinion in Calder appears to equate the defendant's requisite intent to cause harm or effects within the forum state with the intent sufficient to impose liability for an intentional tort (i.e., knowledge to a substantial certainty that harm will result). ${ }^{54}$ However, for jurisdictional purposes, that knowledge must relate to the likelihood of harm in the forum state, rather than the likelihood of harm to the plaintiff. Nevertheless, some courts appear to have read the express targeting language of Calder to endorse some sort of subjective intent or motivation to cause harm to the plaintiff in the forum. ${ }^{55}$ Post-Calder decisions applying the effects test in cases involving intentional personal torts, business torts, and torts committed by means of the Internet have evidenced considerable confusion over the kind of intent that is relevant in applying the Calder test. ${ }^{56}$

A second unanswered question raised by Calder is what relationship that decision's effects test bears to the purposeful availment requirement for personal jurisdiction adopted by the Supreme Court in interstate business cases. Although Calder itself never relies on the purposeful availment standard, some post-Calder personal jurisdiction cases have treated the effects test as an alternative way to establish purposeful availment. ${ }^{57}$ Others have treated it as a separate test for personal jurisdiction that applies in intentional tort cases. ${ }^{58}$ These conflicting currents are addressed below.

52. Id. (emphasis added).

53. See RESTATEMENT (SECOND) Of TORTS § 8A (1967); FowLER V. HARPER, Fleming JAMES, JR., \& OSCAR S. GRAY, THE LAW OF TORTS $§ 3.3$ (3d ed. 1996) ("A result is intended if the act is done for the purpose of accomplishing the result or with knowledge that to a substantial certainty such a result will ensue."); accord DAN B. DOBBS, THE LAw OF TORTS $§ 24$ (2000).

54. See supra text accompanying notes $46-52$.

55. See infra note 88.

56. See infra Part II.B.

57. See infra text accompanying notes 113-19.

58. See infra text accompanying notes 121-28. 


\section{The Zippo Sliding Scale Test, Developed in the Context of Internet Activities}

In Zippo Manufacturing Co. v. Zippo Dot Com, Inc., ${ }^{59}$ an early but influential case considering personal jurisdiction in cases involving wrongs committed by means of the Internet, the court used a sliding scale to determine whether the operation of a Web site can support the minimum contacts necessary for the exercise of personal jurisdiction. The Zippo Court distinguished three levels of Internet activity to measure an Internet site's connections to a forum state. ${ }^{60}$ At one end is a "passive" Web site, "where a defendant has simply posted information on an Internet Web site which is accessible to users in foreign jurisdictions." ${ }^{, 61}$ Under Zippo, maintenance of such a passive site is not sufficient alone to support the exercise of personal jurisdiction in another state where a user may access it. ${ }^{62}$ The "middle ground is occupied by interactive Web sites where a user can exchange information with the host computer." ${ }^{33}$ In these cases, "the exercise of jurisdiction is determined by examining the level of interactivity and commercial nature of the exchange of information that occurs on the Web site."

59. 952 F. Supp. 1119, 1124 (W.D. Pa. 1997) (applying the sliding scale to personal jurisdiction analysis and finding personal jurisdiction over a California corporation "doing business" over the Internet by contracting with approximately 3000 individuals and seven Internet access providers in Pennsylvania to permit "downloading of the electronic messages" that formed the basis of the suit).

Six circuits, including the Fourth, Fifth, Sixth, Ninth, Tenth and D.C. Circuits have expressed approval for or applied the Zippo test. In addition, 164 decisions of federal and state courts involving Internet jurisdiction have cited Zippo, with forty-six of these occurring since the start of 2001. Denis T. Rice \& Julia Gladstone, An Assessment of the Effects Test in Determining Personal Jurisdiction in Cyberspace, 58 Bus. LAW. 601, 602 (2003); see also ALS Scan, Inc. v. Digital Serv. Consultants, Inc., 293 F.3d 707, 714-15 (4th Cir. 2002) (adopting and adapting the Zippo sliding scale test); Neogen Corp. v. Neo Gen Screening, Inc., 282 F.3d 883, 890 (6th Cir. 2002) (applying the Zippo test and finding jurisdiction over Pennsylvania defendant because of a Web site consisting primarily of "passively posted information," since it also provided passwords to Michigan residents to access their blood test results on the site as part of their service contracts, and showed results of screening 4579 infant deaths that included a breakdown for Michigan, which suggested that defendant used data collected from Michigan residents); GTE New Media Servs. Inc. v. BellSouth Corp., 199 F.3d 1343, 1348 (D.C. Cir. 2000) (relying on Mink and Cybersell, progeny of Zippo, to refuse finding jurisdiction over nonresident telephone companies simply because their online Yellow Pages could be accessed from the forum); Soma Med. Int'l v. Standard Chartered Bank, 196 F.3d 1292, 1297, 1299 (10th Cir. 1999) (failing to find jurisdiction over a "passive Web site"); Mink v. AAAA Dev. L.L.C., 190 F.3d 333, 336 (5th Cir. 1999) (using the Zippo sliding scale and finding a printable mail-in form, a toll-free call-in number, a posted e-mail address and a "passive" Web site that did not take orders were not enough to establish jurisdiction in Texas over a Vermont Web site operator).

60. See Zippo Mfg., 952 F. Supp. at 1124 (discussing the three levels of Internet activity).

61. Id.

62. See id. ("A passive Web site that does little more than make information available to those who are interested in it is not grounds for the exercise of personal jurisdiction.").

63. Id.

64. Id. 
of the scale are "situations where a defendant clearly does business over the Internet." If a defendant "enters into contracts with residents of a foreign jurisdiction that involve the knowing and repeated transmission of computer files over the Internet, personal jurisdiction is proper." 66

The Zippo test relies on objective factors in determining whether the exercise of jurisdiction is proper. The greater the quantum of defendant's Web site activities, the more likely the court is to uphold jurisdiction. The Zippo test differs from the traditional purposeful availment test in that it does not apparently rely on the quantum and nature of all of defendant's activities with respect to the forum, but on the level of interactivity demonstrated by the defendant's Web site alone. Zippo's sliding scale categories do not consider defendant's non-Internet contacts with the forum state. For example, the Web site of a defendant which advertises but does not sell beachwear to California residents may not be interactive enough to sustain jurisdiction under the Zippo test, but the defendant's other contacts with California may be sufficient to satisfy the purposeful availment test. Zippo also differs from the Calder effects test. For instance, the general interactivity of a Web site may be adequate to satisfy Zippo, regardless of whether it is targeted toward a specific state. ${ }^{67}$

\section{CONFUSION REGARDING THE APPLICABILITY, MEANING, AND RELATIONSHIP OF THE VARIOUS CONTEXT-SPECIFIC TESTS FOR PERSONAL JURISDICTION}

The presence of multiple, context-specific tests for personal jurisdiction has created undesirable uncertainty as to which of the tests should be applied to particular cases, as well as to the meaning of and relationship among those tests.

\section{A. Which Test Applies?}

For example, Calder arose in the print defamation context, and routinely has been applied by courts in similar cases. ${ }^{68}$ However, where the defamatory material has been

65. Id.

66. Id. The Zippo Court also noted that " $[\mathrm{t}]$ raditionally, when an entity intentionally reaches beyond its boundaries to conduct business with foreign residents, the exercise of specific jurisdiction is proper." Id.

67. Several commentators have criticized the Zippo framework as an inappropriate approach to Internet jurisdiction cases. See Borchers, supra note 9, at 479, 489 (commenting that the Zippo framework "should be ignored, at least in libel cases"); Robert M. Harkins, Jr., The Legal World Wide Web: Electronic Personal Jurisdiction in Commercial Litigation, or How to Expose Yourself to Liability Anywhere in the World with the Press of a Button, 25 PEPP. L. REV. 451, 475-76 (1997); Daniel Steuer, Comment, The Shoe Fits and the Lighter is Out of Gas: The Continuing Utility of International Shoe and the Misuse and Ineffectiveness of Zippo, 74 U. CoLo. L. REv. 319, 321 (2003).

68. See Remick v. Manfredy, 238 F.3d 248, 254, 259 (3d Cir. 2001) (applying Calder in a print defamation case involving allegedly defamatory letters about a boxer sent to the forum state where the court found that the letters were not expressly aimed at the forum state and the forum state did not have a "unique relationship" with the boxing industry as the motion picture industry did with California in Calder); Noonan v. Winston Comp., 135 F.3d 85, 91 (1st Cir. 1998) (applying Calder to print defamation case where the court noted that defendants did not expressly aim activity at the forum state because "[t]he size of a distribution of offending 
posted on the Internet, at least one court has applied Zippo as the primary controlling authority. ${ }^{69}$ The court did assert that Zippo and Calder were not "in tension" but this is doubtful. ${ }^{70}$ Similarly, where defamation claims have arisen in the context of the conduct of interstate business activities, some courts have relied primarily upon the purposeful availment test of Burger King while also referring to Calder. ${ }^{11}$ By contrast, other courts have relied primarily upon the Calder test in such cases while referring incidentally to purposeful availment. ${ }^{72}$

Many courts have applied Calder to cases alleging intentional torts other than defamation. Claims subjected to Calder's express aiming or intentional targeting requirements have included trademark infringement, RICO violations, misappropriation of trade secrets, unfair competition, trademark dilution, tortious interference with contract, fraud, and breach of fiduciary duty. ${ }^{73}$ But other courts have inconsistently applied Burger King to the same torts where they arose in the business

material helps determine whether a defendant acted intentionally" and that "[j] ust as widespread circulation of a publication indicates deliberate action," so "thin distribution" may indicate a lack of purposeful contact); Chaiken v. VV Publ'g Corp., 119 F.3d 1018, 1028 (2d Cir. 1997) (applying Calder to a print defamation case where defendant did not "expressly aim[]" its actions at Massachusetts since he "only sent four copies" of the publication to the forum state and "had no reason to think that the brunt of the harm would be felt there").

69. See Revell v. Lidov, 317 F.3d 467, 472-73 (5th Cir. 2002) (applying Zippo and Calder to an Internet defamation case, first finding that the Web site was not interactive under Zippo and then finding that the defendant did not expressly aim allegedly defamatory statements toward residents of the forum state).

70. Id. at 471-72 (noting that the "Zippo scale" is not in conflict with the Calder effects test for intentional torts).

71. See Gordy v. Daily News, 95 F.3d 829, 832 (9th Cir. 1996) (noting that the purposeful availment factor "undergoes a certain amount of distortion" when jurisdiction is based on an intentional act committed outside the forum that has intended effects within the forum and that it is difficult to see how such a foreign actor "invoke[s] the benefits and protections of [the forum's] laws").

72. See Noonan v. Winston Comp., 135 F.3d 85, 90 (1 st Cir. 1998).

73. See Harris Rutsky \& Co. Ins. Servs. v. Bell \& Clements Ltd., 328 F.3d 1122 (9th Cir. 2003) (relying on the Calder effects test in a tortious interference case); Dole Foods Co. v. Watts, 303 F.3d 1104 (9th Cir. 2002) (applying express aiming requirement in a case involving fraud, deceit, breach of fiduciary duty, and conversion); Wien Air Alaska, Inc. v. Brandt, 195 F.3d 208, 212 (5th Cir. 1999) (sustaining jurisdiction under Calder over German attorney for Texas corporation in fraud, breach of contract, and breach of fiduciary duty action); IMO Indus., Inc. v. Kiekert AG, 155 F.3d 254, 263 (3d Cir. 1998) (holding that feeling the effects of defendant's tortious interference in a state is insufficient to satisfy the "express aiming" requirement of Calder); Panavision Int'l v. Toeppen, 141 F.3d 1316 (9th Cir. 1998) (applying Calder in trademark dilution action and finding that purposeful availment was satisfied by "effects felt in California, the home state of Panavision" from out-of-state defendant's plan to register domain names using the trademarks); ESAB Group, Inc. v. Centricut, Inc., 126 F.3d 617, 625-26 (4th Cir. 1997) (applying Calder in failing to find jurisdiction in a RICO case arising from misappropriation of plaintiff's trade secrets); Far West Capital, Inc. v. Towne, 46 F.3d 1071, 1071-72 (10th Cir. 1995) (applying Calder in breach of contract and intentional interference with contractual relations case and failing to find jurisdiction); Indianapolis Colts, Inc. v. Metro. Balt. Football Club Ltd. P'ship, 34 F.3d 410, 411-12 (7th Cir. 1994) (applying Calder in a trademark infringement suit where the defendant had broadcast its games on cable television; since the injury occurred in Indiana, defendants were amenable to suit there). 
context $^{74}$ or Zippo where defendant's alleged misconduct was committed on the Internet. $^{75}$

Rather than applying one or the other of the jurisdictional tests just reviewed, some courts have amalgamated them. For example, in ALS Scan, Inc. v. Digital Service Consultants, Inc., ${ }^{76}$ the Fourth Circuit stated that it would "adopt[] and adapt[]" the Zippo standard in resolving issues of personal jurisdiction based on Internet activities. ${ }^{77}$ The court concluded that

a State may, consistent with due process, exercise judicial power over a person outside of the State when that person (1) directs electronic activity into the State, (2) with the manifested intent of engaging in business or other interactions within

74. See, e.g., Panda Brandywine Corp. v. Potomac Elec. Power Co., 253 F.3d 865, 867-68 (5th Cir. 2001) (applying the Burger King purposeful availment test to a tortious interference claim); CompuServe, Inc. v. Patterson, 89 F.3d 1257, 1263-64 (6th Cir. 1996) (applying the Burger King purposeful availment requirement to an action seeking declaratory judgment regarding trademark infringement); Far West Capital, Inc., 46 F.3d at 1077 n.5 (involving allegations of breach of contract and intentional interference with contractual relations, where the court stated that plaintiff cited "no clear authority for establishing personal jurisdiction based upon an intentional tort theory when the focus of the relationship is a contract not centered in the forum state").

75. See Neogen Corp. v. Neo Gen Screening, Inc., 282 F.3d 883, 890 (6th Cir. 2002) (finding jurisdiction over Pennsylvania defendant under Zippo because the defendant's Web site provided passwords to Michigan residents to access their blood test results on the site as part of their service contracts, and showed results of screening 4579 infant deaths that included a breakdown for Michigan, which suggested that defendant used data collected from Michigan residents); GTE New Media Servs. Inc. v. BellSouth Corp., 199 F.3d 1343, $1348-49$ (D.C. Cir. 2000) (relying on Mink and Cybersell, progeny of Zippo, in refusing to find jurisdiction over nonresident telephone companies simply because their online Yellow Pages could be accessed from the forum); Soma Med. Int'l v. Standard Chartered Bank, 196 F.3d 1292, 1297, 1299 (10th Cir. 1999) (failing to find jurisdiction over "passive Web site" under Zippo); Mink v. AAAA Development L.L.C., 190 F.3d 333, 336 (5th Cir. 1999) (finding a printable mail-in form, a tollfree call-in number, a posted e-mail address and a "passive" Web site that did not take orders were not enough to establish jurisdiction in Texas over a Vermont Web site operator in a case involving patent infringement); Cybersell, Inc. v. Cybersell, Inc., 130 F.3d 416, 418-19 (9th Cir. 1997) (applying the traditional minimum contacts test and the Zippo test to determine that defendant did not satisfy purposeful availment); Zippo Mfg. Co. v. Zippo Dot Com, Inc., 952 F. Supp. 1119, 1124 (W.D. Pa. 1997) (finding personal jurisdiction over a California corporation in a trademark infringement action where the corporation was "doing business" over the Internet by contracting with approximately 3000 individuals and seven Internet access providers in Pennsylvania to permit "downloading of the electronic messages" that formed the basis of the suit); see also ALS Scan, Inc. v. Digital Serv. Consultants, Inc., 293 F.3d 707, 714-15 (4th Cir. 2002) (adopting and adapting the Zippo sliding scale test in a copyright infringement case). But see EDIAS Software Int'l v. Basis, 947 F. Supp. 413, 420, 422 (D. Ariz. 1996) (using the Calder effects test rather than Zippo to exercise jurisdiction based on Internet activity).

76. 293 F.3d 707 (4th Cir. 2002).

77. Id. at 714. In ALS Scan, the Maryland owner of copyrighted photographs, ALS, brought a copyright infringement action against Digital, a Georgia Internet service provider (ISP) that hosted a Web site posting allegedly infringing pictures. See id. at 709. 
the State, and (3) that activity creates, in a person within the State, a potential cause of action cognizable in the State's courts. ${ }^{78}$

Although purporting to apply Zippo, the court pointed out that the above standard is "not dissimilar to that applied by the Supreme Court in Calder v. Jones." In contrast to Zippo, which emphasizes the level of interactivity of the defendant's Web site, the $A L S$ test focuses on purposeful targeting of a particular forum by analogy to Calder. ${ }^{80}$

Sometimes, the same court has applied differing tests to circumstances that seem factually indistinguishable. This problem is illustrated by Bancroft \& Masters, Inc. $v$. Augusta National, Inc. ${ }^{81}$ and Cybersell, Inc. v. Cybersell, Inc., ${ }^{82}$ two Ninth Circuit trademark infringement cases with similar facts. One decision applied Calder to sustain the exercise of jurisdiction while the other explicitly refused to apply Calder and applied Zippo instead in rejecting jurisdiction. ${ }^{83}$ As discussed below, ${ }^{84}$ the differing

78. Id. (emphasis added). In applying this test, the court noted that personal jurisdiction could not be exercised over Digital for its role as an ISP since Digital did not "select or knowingly transmit infringing photographs specifically to Maryland with the intent of engaging in business or any other transaction in Maryland." Id. at 714-15 (emphasis added).

79. Id. at 714 .

80. See Graduate Mgmt. Admission Council v. Raju, 241 F. Supp. 2d 589, 594 (E.D. Va. 2003) (noting that $A L S$ emphasizes "purposeful targeting of a particular forum, not just the level of interactivity" to meet the purposeful availment prong of the Due Process test (emphasis in original).

81. 223 F.3d 1082 (9th Cir. 2000).

82. 130 F.3d 414 (9th Cir. 1997).

83. In Cybersell, the Ninth Circuit applied the Zippo test and rejected personal jurisdiction over a "passive" Web site. The court found that personal jurisdiction was lacking in Arizona over a Florida company, Cybersell FL, that had posted an "essentially passive home page on the [W]eb," using the name "CyberSell," which Cybersell AZ, an Arizona Company, was in the process of registering as a federal service mark. Id. at 419. The record illustrated that "CyberSell FL did nothing to encourage people in Arizona to access its site, and there is no evidence that any part of its business . . . was sought or achieved in Arizona." Id. When Cybersell AZ found out about Cybersell FL infringing on its service mark, Cybersell $\mathrm{AZ}$ sent an e-mail to Cybersell FL notifying it of its mark. The Court of Appeals in Cybersell rejected the use of the Calder effects test in this setting. The court stated that there is "nothing comparable about Cybersell FL's [W]eb page," to Calder, and that the Calder effects test does not "apply with the same force" to a corporation as an individual because a corporation "does not suffer harm in a particular location in the same sense that an individual does." Id. at 420 (quoting Core-Vent Corp. v. Nobel Indus. AB, 11 F.3d 1482, 1486 (9th Cir. 1993)).

Despite the holding in Cybersell, the Ninth Circuit in Bancroft \& Masters applied the Calder effects test in a trademark dilution and infringement case. A California computer services company, Bancroft \& Masters, Inc. ("B \& M") brought suit against a Georgia golf club, Augusta National Inc. ("ANI") for a declaration of non-infringement of ANI's trademark. ANI, which held several federally registered trademarks for the mark "masters" and operated a Web site at the domain name "masters.org," sent a letter to Network Solutions, Inc. (NSI), the Virginia company that registered the domain name "masters.com" to B \& M. Bancroft \& Masters, 223 F.3d at 1084-85. The letter to NSI challenged B \& M's use of the domain name "masters.com" and "demand[ed] that $B \& M$ cease and desist its use of masters.com and transfer it immediately to ANI." Id. at 1085. The court found that under Calder, ANI had "expressly aimed" its activity at California by sending its cease-and-desist letter to NSI. See id. at 1088 ("ANI acted 
results in the two cases can be justified on other grounds, but there is no clear distinction between them that would justify the use of separate jurisdictional tests in reaching those results.

\section{B. What Do the Various Personal Jurisdiction Tests Mean?}

Beyond confusion as to which of the various personal jurisdiction tests to apply, uncertainty regarding their meaning also is prevalent. Particularly where the Calder test has been applied, courts have evidenced considerable confusion as to the meaning of its express aiming or intentional targeting requirement. ${ }^{85}$ As the Ninth Circuit in Bancroft \& Masters recognized, the express aiming requirement "hardly defines itself., ${ }^{86}$ Obviously, the test focuses on a defendant's purpose or intent, but what kind of purpose and what sort of intent? The Supreme Court's opinion in Calder gives very little guidance on this question. In holding that the individual defendants in that action "knew" that the brunt of the harm caused by their allegedly defamatory article would be felt by the plaintiff in California, ${ }^{87}$ the court did not clearly indicate whether a desire or purpose to harm the plaintiff in California was required, or whether it was sufficient that defendants merely were aware that such harm would occur there, or whether jurisdiction should be sustained if defendants merely should have been aware that the primary impact of their conduct would occur in California. Nor did the Court indicate whether purpose or knowledge that a particular plaintiff would suffer harm in the state was required, or whether it was sufficient that the defendants were or should have been aware that some industry or person might suffer predictable harm there as a result of their conduct.

These ambiguities have led to widespread divergence among the lower courts. Some courts have suggested that something close to a subjective purpose or desire to harm the plaintiff in the forum state is required. ${ }^{88}$ Most courts have focused on the

intentionally when it sent its letter to NSI. The letter was expressly aimed at California ....").

The only relevant factual differences between the two situations were that in Bancroft the trademark holder sent a letter to a third party which sparked a declaratory judgment action by the alleged infringer, whereas Cybersell involved a suit by the trademark owner (Cybersell AZ) after it had given notice to the alleged infringer. This difference does not change the fact that ANI's letter to a third-party about the acts of a California company seems less "targeted" at California than Cybersell FL's refusal to comply with Cybersell AZ's e-mail since ANI's letter was first sent to a third party in Virginia. Just as ANI should have known that B \& $M$ held a Web site and that B \& M, a California company, would be affected when the NSI dispute resolution process was triggered, so Cybersell FL should have known, after receiving the e-mail from Cybersell $\mathrm{AZ}$, that by continuing to use the "CyberSell" title, it was potentially affecting Cybersell AZ, the Arizona company that owned the service mark. Regardless of whether the trademark owner or alleged infringer initiates suit, however, the substance of the underlying dispute was the same, and if the Calder effects test was relevant in one context, it was relevant in both.

84. See infra note 308 and text accompanying notes 309-14.

85. See Bancroft \& Masters, 223 F.3d at 1088.

86. Id. at 1087.

87. For a discussion of Calder, see supra text accompanying notes $46-58$ for discussion of Calder.

88. See, e.g., IMO Indus., Inc. v. Kiekert AG, 155 F.3d 254, 263 (3d Cir. 1998) (stating that knowledge alone is insufficient to satisfy the "express aiming" requirement; rather the defendant 
defendants' awareness that their conduct would cause harm in the forum state-an interpretation that most closely corresponds with the Supreme Court's language in Calder. ${ }^{89}$ However, some courts have gone further by indicating that the critical issue is not whether the defendants were in fact aware that their tortious conduct would have effects in the forum, but only whether they should have been aware that it would. ${ }^{90}$

And if awareness is the key, awareness of what? Is it sufficient that the defendants are or should be aware that the primary effects of their conduct would be felt by the plaintiff in a particular state? Many courts have stated that such awareness is not alone sufficient to satisfy Calder's express aiming requirement, and that something more must be required before the express aiming or targeting requirement is met. However, these courts do not clearly define what else is required beyond a defendant's awareness that its conduct will have a substantial or primary impact on the plaintiff in a particular state. ${ }^{91}$ But even on this point, a minority view holds that "there can be no serious

must manifest behavior "intentionally targeted and focused" on the forum); Bancroft \& Masters, 223 F.3d at 1088 (explaining that foreseeable effects in the forum not are not enough and that there must be express aiming which is satisfied when the defendant performs acts for the "very purpose" of having effects in the forum, that is, individually targeting a plaintiff who the defendant knows is a resident of the state).

89. See Revell v. Lidov, 317 F.3d 467, 475 (5th Cir. 2002) (focusing on the defendant's awareness of the forum at which its conduct was directed); Panda Brandywine Corp. v. Potomac Elec. Power Co., 253 F.3d 865, 869 (5th Cir. 2001) (emphasizing that knowledge was important and that the tortious interference alleged was directed at financing agreements not to be performed and having no relationship with Texas); Noonan v. Winston Comp., 135 F.3d 85, 91 (1st Cir. 1998) (focusing on defendant's awareness of harm reaching the forum state in determining jurisdiction under Calder).

90. See Chaiken v. VV Publ'g Corp., 119 F.3d 1018, 1029 (2d Cir. 1997) (rejecting jurisdiction where Israeli defendant had "no reason to think" that the brunt of harm would be suffered in Massachusetts; rather, defendant had "reason to believe" that the effects would be felt in Israel); Gordy v. Daily News, 95 F.3d 829, 836 (9th Cir. 1996) (sustaining jurisdiction because defendants knew that the plaintiff resided in California and had "reason to expect" that the impact of their activities would be felt there).

91. See Revell, 317 F.3d at 473 (noting that the plaintiff's residence and harm taking place in Texas were insufficient in an Internet defamation case where the article in question did not refer to the plaintiff's Texas activities and was not directed at a Texas audience); Bancroft \& Masters, 223 F.3d at 1087 (noting that foreseeable effects in the forum are insufficient); Wien Air Alaska, Inc. v. Brandt, 195 F.3d 208, 213-14 (5th Cir. 1999) (commenting that foreseeable injury in the forum alone is not enough absent the direction of specific acts to the forum, which in this case included the transmission of letters, faxes and phone calls containing the fraudulent representations); IMO Indus., Inc., 155 F.3d at 261-62 (in an action for tortious interference with the sale of a New Jersey Corporation's Italian subsidiary to a French competitor of the German defendant, the court explained that jurisdiction in New Jersey was improper even though the defendant knew that the "brunt of the harm" would be suffered by plaintiff in New Jersey; courts applying Calder to business torts have adopted a "narrow construction" and it is not enough that the defendant knows that the plaintiff's principal place of business is in the forum); Panavision Int'l v. Toeppen, 141 F.3d 1316, 1322 (9th Cir. 1998) (trademark infringement case, requiring more than merely registering a trademark and placing it on a Web site with knowledge plaintiff would suffer the brunt of the harm in forum state where plaintiff's principal place of business was located, but sustaining jurisdiction because defendant attempted to extort money from plaintiff in California in response to a cease-and-desist letter); ESAB Group, Inc. v. Centricut, Inc., 126 F.3d 617, 625-26 (4th Cir. 1997) (noting that it was 
doubt" after Calder that the state in which the victim of a tort suffers injury can exercise personal jurisdiction over the defendant. ${ }^{92}$

Additional uncertainty about the proper interpretation of the express aiming requirement in Calder cases was created by the California Supreme Court's closely divided opinion in Pavlovich $v$. Superior Court, ${ }^{93}$ described in the introduction. The question in Pavlovich was whether a defendant's awareness that the particular plaintiff would suffer harm in the forum is a requirement of Calder's express aiming requirement. In Pavlovich, the court, by a four-to-three vote, rejected jurisdiction in California over a Texas Web site operator who had posted software designed to defeat the plaintiff licensor's technology for encrypting copyrighted motion pictures on DVDs.

The majority began its analysis by noting that in the area of personal jurisdiction "few answers will be written in black and white. [Shades of] grey are dominant." The court referred in passing to Burger King's purposeful availment test, noting that it focuses on the "defendant's intentionality." to an application of the Calder effects test on the ground that it applies to intentional torts generally, including business torts. ${ }^{96}$ Noting that application of Calder had been "less than uniform," and that courts applying Calder to nondefamation cases had adopted "a mixture of broad and narrow interpretations," 97 the majority concluded that most courts agreed that the assertion, without more, that a defendant knew or should have known that his intentional acts would cause harm in the forum state was not sufficient to establish jurisdiction. ${ }^{98}$ Instead, plaintiff must show that the defendant knew that the plaintiff would suffer the brunt of the harm caused by the tortious activity in the forum and "point to specific activity indicating that defendant expressly aimed its tortious conduct at the forum."99

Finally, the majority concluded that it was not sufficient that the defendant knew or should have known that the information posted would harm the motion picture, computer, and consumer electronic industries centered in California. ${ }^{100}$ The relevant question was not whether the defendant knew or should have known that its conduct might have an industry-wide effect in the forum state, but rather whether the defendant

insufficient that the defendant knew that its scheme, if successful, would result in lost sales by company headquartered in South Carolina and that a contrary holding would always sustain jurisdiction in the plaintiff's home state).

92. Janmark, Inc. v. Reidy, 132 F.3d 1200, 1202-03 (7th Cir. 1997) (sustaining jurisdiction in Illinois under Calder over claim for interference with economic advantage where defendant threatened the Illinois plaintiff's customer in New Jersey with infringement, leading the New Jersey customer to cancel its contract with the plaintiff).

93. 58 P.3d 2 (Cal. 2002).

94. Id. at 6 (quoting Kulko v. Superior Court, 436 U.S. 84, 92 (1978)).

95. Id. at 7 (quoting U.S. v. Swiss Am. Bank, Ltd., 274 F.3d 610, 623 (1 st Cir. 2001)).

96. See id. ("Although Calder involved a libel claim, courts have applied the effects test to other intentional torts, including business torts.").

97. Id. at 7-8 (quoting IMO Indus., Inc. v. Kiekert AG, 155 F.3d 254, 261 (3rd Cir. 1998)).

98. Id. at 8 (" $[\mathrm{M}]$ ost courts agree that merely asserting that a defendant knew or should have known that his intentional acts would cause harm in the forum state is not enough to establish jurisdiction under the effects test.").

99. Id. (quoting IMO Indus., 155 F.3d at 266).

100. Id. at 11-12. 
had intentionally targeted the particular plaintiff in the forum. ${ }^{101}$ That requirement was not satisfied because the defendant did not know that the plaintiff licensing entity was located in California, and because the unilateral acts of Web site users in downloading the information in question could not satisfy the express aiming requirement. ${ }^{102}$

Three dissenting Justices took a completely different approach. In their view, the intended targets of the defendant's conduct "were not individual persons or businesses, but entire industries." 103 The defendant knew that at least two of the industries targeted in their effort to defeat the encryption technology, the motion picture and computer industries, were located in California. ${ }^{104}$ It did not matter that the defendant did not know the precise identities or locations of each targeted individual. ${ }^{105}$

Even Burger King's purposeful availment test has proved less than self-defining. The Supreme Court has offered a variety of formulations of the requirement. In Burger King, for example, the Court variously referred to the test as requiring that the defendant have "purposefully directed his activities at residents of the forum," 106 that the defendant "purposefully establish 'minimum contacts' in the forum state,"107 and that the defendant "purposefully avail[] itself of the privilege of conducting activities within the forum state, thus invoking the benefits and protections of its laws." 108 Each of these formulations differs from the others, and may lead to different results in differing cases. For example, in a case where the defendant's activities are not commercial, the first and second formulations might sustain jurisdiction, while the last might not. Similarly, purposefully establishing minimum contacts with the forum is a more flexible and inclusive articulation that might reach beyond a case in which a defendant had purposefully directed its activities at residents of the forum. This is particularly true if, as some courts have done, the latter requirement is interpreted in a way that requires the defendant to have targeted particular forum residents. ${ }^{109}$ Lower courts have similarly articulated a plethora of differing formulations of the Burger King test. ${ }^{110}$

101. Id. at 8-9.

102. Id. at $10-13$. The majority noted that even if the defendant should have learned who the licensor was, he could not have known this fact when the posting occurred because the plaintiff was not formed until later. Id. at 11.

103. Id. at 14.

104. Id.

105. Id.

106. Burger King Corp. v. Rudzewicz, 471 U.S. 462, 472 (1985) (citation omitted).

107. Id. at 474 (quoting Int'l Shoe Co. v. Washington, 326 U.S. 310,316 (1945)).

108. Id. at 475 (quoting Hanson v. Denckla, 357 U.S. 235, 253 (1958)).

109. See Pavlovich, 58 P.3d at 11.

110. See, e.g., Soma Med. Int'l v. Standard Chartered Bank, 196 F.3d 1292, 1298 (10th Cir. 1999) (requiring defendant to purposefully direct activities at residents of the forum state); Wien Air Alaska, Inc. v. Brandt, 195 F.3d 208, 213 (5th Cir. 1999) (noting that defendant must "purposefully avail himself of the privilege of causing a consequence" in the forum); ESAB Group, Inc. v. Centricut, Inc., 126 F.3d 617, 623 (4th Cir. 1997) (requiring defendant to engage in some activity "purposefully directed" to the forum state); Gordy v. Daily News, 95 F.3d 829, 831-32 (9th Cir. 1996) (explaining that defendant must do some act or consummate some transaction with the forum by which he purposefully avails himself of the privilege of conducting activities in the forum; noting that the purposeful availment test "undergoes a certain amount of distortion" in intentional tort cases); CompuServe, Inc. v. Patterson, 89 F.3d 1257, 
The Zippo formulation for Internet cases has proven equally indeterminate. Most apparently, this is because Zippo provides no guidance as to how cases falling into its middle category of "interactive" Web sites should be resolved, other than the opaque observation that in this area, whether the exercise of jurisdiction is proper is to be determined by examining the "level of interactivity" and the "commercial nature of the exchange of information" over the site. ${ }^{11}$ A number of courts applying Zippo to cases involving Internet activities have found its formulation inadequate and have resorted to either the Burger King purposeful availment or Calder targeting formulation to resolve the cases before them, invoking all of the ambiguities and uncertainties inherent in those approaches. ${ }^{112}$

\section{What is the Relationship Among the Various Jurisdictional Tests?}

Beyond uncertainty over the meaning of the various purpose, effects, and express aiming or targeting requirements and the kinds of cases to which they should be applied, courts have evidenced confusion over the relationship between and among the various tests. In Far West Capital $v$. Towne, ${ }^{113}$ a Tenth Circuit case involving breach of contract and tortious interference claims, the court noted that there was no clear authority for applying Calder analysis to intentional tort cases where the focus of the relationship of the parties was contractual. ${ }^{114}$ However, the court then went on to analyze and reject jurisdiction under Calder on the ground that an allegation, without more, that an out-of-state defendant had injured a forum resident by interfering with its contractual rights was insufficient. ${ }^{115}$ The court apparently viewed Calder's targeting test as simply one manifestation of analysis under Burger King's purposeful availment test in cases involving contractual relations.

Other courts similarly have regarded Calder as synonymous with the purposeful availment requirement of Burger King. ${ }^{116}$ For example, in Bancroft \& Masters, Inc. $v$.

1263 (6th Cir. 1996) (focusing on Burger King's requirement that defendant must take acts that purposefully create "a substantial connection" with the forum state); Far West Capital, Inc. v. Towne, 46 F.3d 1071, 1074 (10th Cir. 1995) (noting that defendant must purposefully avail itself of the privilege of conducting activities within the forum state).

111. See Zippo Mfg. Co. v. Zippo Dot Com, Inc., 952 F. Supp. 1119, 1124 (W.D. Pa. 1997).

112. See, e.g., Carefirst of Md., Inc. v. Carefirst Pregnancy Ctrs., 334 F.3d 390, 397-401 (4th Cir. 2003) (applying ALS, Zippo, and Calder to reject jurisdiction in Maryland in a trademark infringement and dilution action based on defendant's operation of a semi-interactive Web site having a "strongly local" Illinois character); Toys "R" Us, Inc. v. Step Two, S.A., 318 F.3d 446, 452 (3d Cir. 2003) (relying on the "purposeful availment" test in applying Zippo to an interactive Web site); Revell v. Lidov, 317 F.3d 467, 472-73 (5th Cir. 2002) (applying Calderlike analysis to personal jurisdiction issue in case involving interactive Web site); Young v. New Haven Advocate, 315 F.3d 256, 262-64 (4th Cir. 2002) (adopting the ALS Scan and Calder tests but relying primarily on Calder in neglecting to consider the interactivity of defendant's Web site and instead focusing on whether the defendant expressly "aimed" conduct at the forum state); ALS Scan, Inc. v. Digital Serv. Consultants, Inc., 293 F.3d 707, 714-15 (4th Cir. 2002) ("adopting and adapting" the Zippo test by adding concepts from Calder and requiring that defendant direct conduct into a state with manifest intent to conduct business within the state).

113. 46 F.3d 1071 (10th Cir. 1995).

114. Id. at 1077 n.5.

115. Id. at 1079.

116. See Harris Rutsky \& Co. Ins. Servs., Inc. v. Bell \& Clements Ltd., 328 F.3d 1122, 1131 
Augusta National Inc., previously discussed, ${ }^{117}$ the Ninth Circuit used the two concepts interchangeably in applying the Calder effects test. The court concluded "that B \& M demonstrated purposeful availment by ANI under the Calder effects test." 18 In determining jurisdiction, the court used the terms "purposeful availment" and "express aiming" interchangeably, and assumed that they had one meaning. Similarly in Pavlovich, the California Supreme Court regarded the Calder effects test as a method of establishing purposeful availment. ${ }^{119}$

Other courts apparently have regarded Calder not as synonymous with Burger King's purposeful availment test, but as one aspect of a broader minimum contacts analysis. ${ }^{120}$ Yet other courts have regarded Calder and Burger King as alternative tests, invoking one or the other depending upon the type of claim that is asserted. ${ }^{121}$ For

(9th Cir. 2003) (explaining that the purposeful availment requirement was satisfied because the defendant had satisfied the Calder effects test); Young, 315 F.3d at 262-63 (stating that purposeful availment is an alternate method of proving that the defendant directed his activities at the forum); Rio Props., Inc. v. Rio Int'l Interlink, 284 F.3d 1007, 1019-20 (9th Cir. 2002) (using the Calder three-prong test as a way to satisfy the purposeful availment requirement); Bancroft \& Masters, Inc. v. Augusta Nat'l, Inc., 223 F.3d 1082, 1088 (9th Cir. 2000) (concluding "that B \& $\mathrm{M}$ has demonstrated purposeful availment by ANI under the Calder effects test"); ESAB Group, Inc. v. Centricut, Inc., 126 F.3d 617, 625-26 (4th Cir. 1997) (discussing the Calder test and purposeful availment as two ways of "grounding jurisdiction"); Graduate Mgmt. Admission Council v. Raju, 241 F. Supp. 2d 589, 595-96 (E.D. Va. 2003) (noting that $A L S$ emphasizes purposeful targeting, "not just the level of interactivity," to meet the purposeful availment prong of the Due Process test and specifically stating that purposeful availment is "an alternate method of proving that the defendant directed his activities at the forum"); see also Columbia Pictures Television v. Krypton Broad. of Birmingham, Inc., 106 F.3d 284, 289 (9th Cir. 1997) (holding that when the defendant willfully infringed copyrights owned by the plaintiff, and the defendant knew the plaintiff's principal place of business was located within in the forum, this alone was sufficient to satisfy the purposeful availment requirement of Calder); Rodriguez Salgado v. Les Nouvelles Esthtiques, 218 F. Supp. 2d 203, 212 (D.P.R. 2002) (where, after applying the Calder effects test, the court held that LNE did not purposefully avail itself in Puerto Rico and lacked minimum contacts); Panavision Int'l, L.P.v. Toeppen, 938 F. Supp. 616, 620-22 (C.D. Cal.1996), aff'd, 141 F.3d 1316 (9th Cir. 1998) (finding that purposeful availment was satisfied using the effects test of Calder when defendant knowingly registered plaintiff's domain names as trademarks and defendant "harmed Panavision, the brunt of which Panavision has borne in California," which defendant "knew would likely happen," because Panavision's principal place of business was in California).

117. See supra notes 81-83.

118. Bancroft, 223 F.3d at 1088 (emphasis added). The court stated that "[ $t]$ he letter was expressly aimed at California because it individually targeted B \& M, a California corporation doing business almost exclusively in California," that "the effects of the letter were primarily felt, as ANI knew that they would be, in California" and that the defendant therefore demonstrated "purposeful availment." Id. (emphasis added).

119. Pavlovich v. Superior Court, 58 P.3d 2, 7 (Cal. 2002) (referring to the Calder effects test as a test for "determining purposeful availment").

120. See Panda Brandywine Corp. v. Potomac Elec. Power Co., 253 F.3d 865, 869 (5th Cir. 2001) (in rejecting personal jurisdiction in the context of tortious interference with a Texas corporation's Maryland financing agreements, the court of appeals stated that the Calder test is not a substitute for facts demonstrating purposeful availment of the benefits of the forum state and that in-state effects are only one part of minimum contacts analysis).

121. See, e.g., Toys "R" Us, Inc. v. Step Two, S.A., 318 F.3d 446, 455 n.6 (3d Cir. 2003) (treating Calder as an "alternative to the 'minimum contacts' analysis for specific jurisdiction"). 
example, in Remick $v$. Manfredy, ${ }^{122}$ the court applied the Burger King test to a breach of contract claim, ${ }^{123}$ but applied Calder to related tort claims for defamation, ${ }^{124}$ misappropriation of image and likeness, ${ }^{125}$ and interference with contractual relations. ${ }^{126}$ In Schwarzenegger v. Fred Martin Motor Co., ${ }^{127}$ the Ninth Circuit distinguished between "purposeful availment," applicable in contract and other cases involving the conduct of business within a state, and "purposeful direction," applicable in tort cases involving extraterritorial conduct, equating the purposeful direction (but not the purposeful availment) standard with the Calder effects test. ${ }^{128}$ Yet other courts have cited and applied both tests, without explaining the relationship, if any, that they saw between them. ${ }^{129}$

Even greater uncertainty has arisen in cases considering the relationship of Zippo, Calder, and Burger King in the context of Internet activities. In Revell v. Lidov, ${ }^{130}$ for example, the Fifth Circuit applied both the Zippo and Calder tests in an Internet defamation action against an online bulletin board and an alleged defamer, asserting (dubiously) that there was no "tension" between the tests. ${ }^{131}$ Revell, a Texas resident, sued Lidov, a Massachusetts resident, and Columbia University for defamation arising out of an article posted on a Columbia University bulletin board. ${ }^{132}$ In applying the Zippo test, the court decided that the bulletin board was "interactive" because individuals could "send information to be posted, and receive information that others have posted," rather than simply "send information" as was the case in Zippo. ${ }^{133}$

Once the court determined that the Columbia site was interactive, the court blurred the Zippo and Calder tests by deciding to "evaluate the extent of this interactivity" with respect to Calder, not Zippo. ${ }^{134}$ However, since the level of interactivity is part of Zippo, not Calder, the court never actually examined the interactivity of the Web site. Rather, applying Calder, the court examined Revell's relationship with Texas and Lidov's subjective knowledge about Revell's status as a Texas resident. The court decided that since the article "contains no reference to Texas ... or Texas activities of Revell, and was not directed at Texas readers as distinguished from readers in other

122. 238 F.3d 248 (3d Cir. 2001).

123. See id. at 256-57.

124. See id. at 257-58.

125. See id. at 259.

126. See id. at 260.

127. 374 F.3d 797 (9th Cir. 2004).

128. Id. at $802-03$.

129. The Supreme Court of Minnesota in Griffis v. Luban, 646 N.W.2d 527, 532 (Minn. 2002) explained that purposeful availment is necessary to establish specific jurisdiction and then went on to explain that in establishing jurisdiction over Griffis the district court "in particular" relied on the Calder effects test.

130. 317 F.3d 467 (5th Cir. 2002).

131. Id. at 472. The court reserved the "difficult question" of whether a "Zippo-passive' site could still give rise to personal jurisdiction under Calder." Id. at 473 n.30.

132. Id. at 469.

133. Id. at 472 (emphasis in original).

134. See id. The court noted that the Calder effects test is "but one facet of the ordinary minimum contacts analysis, to be considered as part of the full range of the defendant's contacts with the forum." Id. at 473 (citing Panda Brandywine Corp. v. Potomac Elec. Power Co., 253 F.3d 865, 869 (5th Cir. 2001)). 
states .. . Texas was not the focal point of the article or the harm suffered." 135 The court further noted that the "sources relied upon and activities described in the allegedly defamatory publication should in some way connect with the forum if Calder is to be invoked." 136 Additionally, the court pointed out that "[k]nowledge of the particular forum in which a potential plaintiff will bear the brunt of the harm forms an essential part of the Calder test." ${ }^{137}$ However, Lidov did not know that Revell was a resident of Texas when he posted the article, so he lacked "knowledge of the forum at which his conduct is directed" and therefore could not reasonably anticipate being haled into court in that forum. ${ }^{138}$ The court concluded that Texas lacked jurisdiction over either defendant under Calder and Zippo. ${ }^{139}$

The court did not mention why it applied both Calder and Zippo. Perhaps it was because the case involved jurisdiction over both an online bulletin board and an individual defendant. The court may have concluded that, with respect to Lidov, an individual, it was most important to determine what he knew about Revell and where he expressly aimed his allegedly defamatory statements. By contrast, since it is difficult to determine what the online bulletin board "knew" and "aimed" to do, the court may have found the more objective Zippo test easier to apply in that context. The court may also have applied Calder in addition to Zippo because Revell was a defamation case which was factually similar to Calder. ${ }^{140}$ However, the court did not hint that either of the two suggested distinctions were relevant to its analysis. It simply applied the Zippo test and then went on to apply Calder as well. In reality, the court attempted to blend two essentially incompatible tests-one which focuses on the defendant's intent, and the other which relies on objective factors relating to the operation of the defendant's Web site. ${ }^{141}$

135. Id. at $\mathbf{4 7 3}$ (noting that plaintiff's residence in the forum, and suffering of harm there, will not alone support jurisdiction under Calder). The court in Panda Brandywine similarly concluded that "[i]f we were to accept Appellants' arguments, a nonresident defendant would be subject to jurisdiction in Texas for an intentional tort simply because the plaintiff's complaint alleged injury in Texas to Texas residents regardless of the defendant's contacts." 253 F.3d at 970.

136. Revell, 317 F.3d at 474 (citing Reynolds v. Int'l Amateur Athletic Fed'n, 23 F.3d 1110, 1120 (6th Cir. 1994)). But see Burt v. Bd. of Regents of Univ. of Neb., 757 F.2d 242, 244-45 (10th Cir. 1985) (upholding application of Calder to support personal jurisdiction in Colorado where a Nebraska doctor had written allegedly defamatory letters about the plaintiff in response to requests from Colorado hospitals, despite the fact that the content of the letters focused on plaintiff's activities in Nebraska not Colorado).

137. Revell, 317 F.3d at 475 .

138. Id. The court additionally noted that "[d]emanding knowledge of a particular forum to which conduct is directed, in defamation cases, is not altogether distinct from the requirement that the forum be the focal point of the tortious activity because satisfaction of the latter will oftimes provide sufficient evidence of the former." Id. at 475-76.

139. See id. at 476.

140. See Rice \& Gladstone, supra note 59, at 629 (noting that "it is logical that defamation is the type of cause of action where the courts can best apply the effects test").

141. Compare Zippo Mfg. Co. v. Zippo Dot Com, Inc., 952 F. Supp. 1119, 1122-24 (W.D. $\mathrm{Pa}$. 1997) (relying solely on objective factors in determining whether to exercise jurisdiction) with Calder v. Jones, 465 U.S. 783, 788-89 (1984) (discussing what defendants knew and if they directed activities at a specific forum and plaintiff). 


\section{THE CASE FOR A UNIFIED AND OBJECTIVE TEST FOR \\ PERSONAL JURISDICTION BASED ON THE GEOGRAPHICALLY SPECIFIC SCOPE THAT THE DEFENDANT SHOULD ASCRIBE TO THE IMPACT OF ITS ACTIVITIES}

\section{A. The Case for a Unified Approach to Issues of Personal Jurisdiction}

In summary, the Supreme Court and lower courts have tended to articulate at least three, apparently distinct, context-specific tests for issues of personal jurisdiction depending on whether a case involves ordinary commercial activities conducted within the forum (Burger King), intentionally tortious activities committed outside the forum having effects within the forum (Calder), or Internet sites accessible from within the forum (Zippo). This context-specific approach has not been justified on policy grounds with one exception. Zippo rests on the concern that maintenance of a passive Web site should not be permitted to subject the defendant to jurisdiction in the home state of anyone who might access it, because the defendant might then be subjected to jurisdiction anywhere in the world. ${ }^{142}$

This context-specific approach should be rejected for a number of reasons. Most apparently, the adoption of differing tests applicable to cases depending on whether they involve interstate business activities, intentional torts, or Internet activities, creates difficulty in selecting which test to apply in cases where more than one of the categories are relevant. Business activities may be conducted over the Internet. ${ }^{143}$ Intentional torts having interstate impacts may be committed over the Internet. ${ }^{144}$ And in some cases, in which tortious activities are committed over the Internet for commercial purposes, all three categories potentially may apply. Courts confronting such cases have adopted differing approaches, some adopting one test, some another,

142. Zippo Mfg. Co., 952 F. Supp. at 1123-24 (explaining that case law revealing that "the likelihood that personal jurisdiction can be constitutionally exercised is directly proportionate to the nature and quality of commercial activity that an entity conducts over the Internet" is appropriate given that the "Internet makes it possible to conduct business throughout the world entirely from a desktop"). See generally Michael A. Geist, Is There a There There? Toward Greater Certainty for Internet Jurisdiction, 16 BERKELEY TECH. L.J. 1345, 1404 (2001) (noting that "[c]ompanies benefit from the assurance that operating an e-commerce site will not necessarily result in jurisdictional claims from any jurisdiction worldwide").

143. E.g., Zippo Mfg. Co., 952 F. Supp. at 1124 (describing situations where the defendant "clearly does business over the Internet"); see also Pontchartrain Mortgage Corp. v. Mortgage Asset Research Inst., Inc., No. Civ.A. 03-2653, 2004 WL 137590, at *2 (E.D. La. Jan. 20, 2004) (analyzing the nature of the mortgage company's Internet business in resolving jurisdictional issue); Graduate Mgmt. Admission Council v. Raju, 241 F. Supp. 2d 589, 591-92 (E.D. Va. 2003) (defendant was sued after selling graduate school test preparation materials over the Internet); Student Advantage, Inc. v. Int'l Student Exch. Cards, Inc., No. 00 Civ. 1971 (AGS), 2000 U.S. Dist. LEXIS 13138, at *12-14 (S.D.N.Y. Sept. 13, 2000) (selling discount cards in New York over the Internet).

144. See Revell v. Lidov, 317 F.3d 467, 469 (5th Cir. 2002) (Internet defamation suit based on a Web site posted by Columbia University in New York that purportedly injured plaintiff in Texas); Young v. New Haven Advocate, 315 F.3d 256, 258 (4th Cir. 2002) (defamation occurring over an Internet Web site, sponsored by a Connecticut newspaper allegedly impacting plaintiff in Virginia). 
and some a combination of the various context-specific tests, without any consensus on how the tests relate to each other or whether they serve the same or differing purposes. $^{145}$

Of course, if the various context-specific jurisdictional tests were merely varying articulations of the same basic approach, the matter would be irrelevant, because outcomes would be consistent no matter which test were applied. But that is not the case. Most obviously, Burger King's purposeful availment and Calder's express aiming or targeting approach appear to focus predominantly on the defendant's purpose or intent. ${ }^{146}$ By contrast, the Zippo test focuses on whether business activities are being conducted over the Internet at one end of the jurisdictional spectrum, on whether the Web site in question is passive at the other, and, in intermediate cases, on an apparently objective examination of "the level of interactivity and the commercial nature of the exchange of information." ${ }^{, 147}$ Moreover, Zippo appears to focus solely on the defendant's Internet activities, whereas the other approaches take the totality of the defendant's contacts with the forum into account. Clearly these different approaches could affect the result in particular cases. For example, if a Web site was purely passive, Zippo would foreclose any possibility of jurisdiction. The other tests, however, to the extent they permit jurisdiction to be based on all of the defendant's activities, might sustain jurisdiction in cases involving a passive Web site where the defendant clearly intended to target a particular victim that he knew was located in the forum state.

Additionally, despite the fact that Burger King and Calder appear to focus on some version of the defendant's purpose and intent, their articulations of the required purpose vary. Burger King is commonly said to require purposeful availment of the benefits and protections of the forum's laws, in contrast with Calder, which requires only that the defendant expressly aim his tortious conduct at the forum state, regardless of any benefits or protections that he might receive. Courts have not interpreted Burger King's purposeful availment requirement to mean more than that the defendant's business activities must have a predictable, geographically specific focus. ${ }^{148}$ They have not required that the defendant know or have reason to know that his activities will cause harm in the forum, or to know of the specific plaintiff's presence in the forum state. ${ }^{149}$ By contrast, no doubt because the targeting language of Calder lends itself easily to that interpretation, some courts applying Calder, such as the California Supreme Court majority in Pavlovich, have suggested that the defendant must have knowledge that the specific plaintiff is located in the forum state, and will bear the

145. See supra Part II.

146. See Burger King v. Rudzewicz, 471 U.S. 462 (1985); Calder v. Jones, 465 U.S. 770 (1984).

147. See Zippo Mfg. Co. v. Zippo Dot Com, Inc., 952 F. Supp. 1119 (W.D. Pa. 1997).

148. See Asahi Metal Indus. Co. v. Superior Court of Cal., 480 U.S. 102, 117-18 (1987).

149. Asahi Metal Industry Co., 480 U.S. 102, 117-18, n.1 (1987) (citing several lower court cases not requiring more activity than placing a product into the stream of commerce); BP Chems. Ltd. v. Formosa Chem. \& Fibre Corp., 229 F.3d 254, 259-62 (3d Cir. 2000) (applying Burger King without considering knowledge of plaintiff's presence in United States relevant); Marriott PLP Corp. v. Tuschman, 904 F. Supp. 461, 465 (D. Md. 1995) (applying Burger King in a fraud and breach of contract case without requiring knowledge of plaintiff's presence in state). 
brunt of the harm there, in order to satisfy that decision's express aiming requirement. $^{150}$

The Supreme Court's purposeful availment decisions have explained that the Due Process Clause serves the dual purpose of protecting the defendant from inconvenient litigation, and of ensuring that the sovereign authority of the states in relation to each other is appropriately confined. ${ }^{151}$ They have adopted a two-part approach under which, at a minimum, the defendant is required to have purposefully established sufficient minimum contacts with the state to warrant the exercise of its sovereign authority. Provided that threshold requirement has been met, courts have required the exercise of jurisdiction to be "reasonable," taking into account the interests of the parties, the forum state, and the interstate judicial system. ${ }^{152}$ This is a balancing test under which the interests of the forum and the plaintiff are balanced against those of the defendant, provided that the defendant has undertaken some deliberate activity establishing a geographically specific connection with the forum. The Court has explained that this requirement for deliberate or purposeful activity exists to place the defendant on notice of the fora in which his activities might subject him to suit, permitting him to take steps to avoid or insure against the risk of harm that his wrongful conduct has created. ${ }^{153}$

There is no apparent reason to distinguish interstate commercial activities, interstate tortious activities, and Internet activities in these respects. The need for deliberate action and sufficient, geographically specific notice to permit the defendant to anticipate the risk of suit in the forum state is relevant to all of them. Equally relevant to all is the inevitable balancing of the interests of the defendant, the plaintiff, and the forum state in determining the reasonableness of the forum's exercise of jurisdiction over disputes arising from harms caused by the defendant's activities. The Internet is simply one means of communication, albeit one which casts a wider, more anonymous, and less geographically predictable sweep than more traditional means. ${ }^{154}$ These differences do not suggest a fundamentally different approach to the propriety of

150. Pavlovich v. Superior Court, 58 P.3d 2, 7-8 (Cal. 2002).

151. Burger King v. Rudzewicz, 471 U.S. 462, 471-72 (1985) (noting that "[t]he Due Process Clause protects an individual's liberty interest in not being subject to the binding judgments of a forum with which he has established no meaningful "contacts, ties, or relations"” and also "operates to restrict state power"); World-Wide Volkswagen Corp. v. Woodson, 444 U.S. 286, 291-92 (1980) (explaining that "[t]he Due Process Clause of the Fourteenth Amendment limits the power of a state court to render a valid personal judgment against a nonresident defendant" and "protects the defendant against the burdens of litigating in a distant or inconvenient forum").

152. World-Wide Volkswagen Corp., 444 U.S. at 292 (requiring courts to consider "the burden on the defendant," "the forum State's interest in adjudicating the dispute," "the plaintiff's interest in obtaining convenient and effective relief," "the interstate judicial system's interest in obtaining the most efficient resolution of controversies," and the "shared interest of the several States in furthering fundamental substantive social policies" in determining whether it is reasonable for a state to exercise jurisdiction over a defendant).

153. Id. at 291 (noting before establishing the five reasonableness factors that "[d]ue process requires that the defendant be given adequate notice of the suit").

154. See Edward A. Morse, State Taxation of Internet Commerce: Something New Under the Sun?, 30 CREIGHTON L. REV. 1113, 1114 (1997) (describing the Internet as a channel of communication providing a "step" in a "trend away from geographical boundaries"). 
exercising personal jurisdiction where Internet activities provide the vehicle for the defendant's wrongful conduct, as opposed to more traditional means of information transmission and exchange. They do, however, suggest a need to articulate a general test for jurisdiction that will take appropriate account of these differences as they bear on the assertion of personal jurisdiction where Internet activities are involved. ${ }^{\text {iss }}$

\section{B. The Case for Rejecting Subjective Purpose or Intent to Cause Harm in the Forum as a Determinant of Personal Jurisdiction}

If an overarching, unified approach to issues of personal jurisdiction is to be adopted, what should that test be? The most obvious question in view of the Supreme Court's articulation of the purposeful availment and express aiming or targeting tests in Burger King and Calder is what role the defendant's purpose should play in personal jurisdiction analysis. Although the meaning of "purpose" in the purposeful availment test has proved elusive, the very phrasing of the Calder test suggests that the

155. Nevertheless, the Supreme Court's decision in Kulko v. Superior Court, 436 U.S. 84 (1978), might be read to support a context-specific approach to issues of personal jurisdictionand in the process, it may have articulated yet another "test" for personal jurisdiction issues applicable in "domestic relations" cases. In Kulko, the Court considered the application of the minimum contacts standard in a domestic relations context. After maintaining a marital domicile in New York for over twenty years during which their two children were born, the parties entered a separation agreement in New York and Mrs. Kulko obtained a Haitian divorce which incorporated the terms of the agreement. Id. at 87. The agreement awarded custody of the children to the father, who continued to reside in New York, during the school year except for certain holidays, provided that they would reside with their mother, who had moved to California, during summer vacations, and provided support payments for the time that they resided with their mother. Id. Later the daughter, and then the son, moved to California to reside with their mother during the school year, and the mother filed an action in Califormia seeking to obtain a California divorce decree and to modify the agreement's custody and support provisions. Id. at 88 . Mr. Kulko contested personal jurisdiction to affect his support obligations in California. Id.

The Supreme Court held that Mr. Kulko had undertaken no "purposeful act" that would permit the exercise of personal jurisdiction over him in California. Of particular pertinence here, the Court rejected the applicability of the Restatement (Second) of Conflict of Laws "effects" test for personal jurisdiction. Id. at 96 . Section 37 of the Restatement (Second) provides that a state has judicial jurisdiction "over an individual who causes effects in the state by an act done elsewhere" with respect to causes of action arising from those effects unless the exercise of jurisdiction is unreasonable. Id. (quoting RESTATEMENT (SECOND) OF CONFLICT OF LAWS § 37 (1971). In doing so, the Court was significantly influenced by the nature of the controversy as one involving "personal domestic relations," rather than the conduct of interstate business affecting in-state residents, or tortious conduct undertaken in one state having predictable effects in another. Id. at 97. However, Kulko more properly is viewed, not as endorsing a variety of context-specific approaches to personal jurisdiction issues, but rather as consistent with a more general test for personal jurisdiction that applies to all kinds of cases, including domestic relations cases. That unified approach focuses on the scope of the defendant's deliberately undertaken activities, be they commercial, tortious, Internet, or domestic. It asks whether engaging in such activities should, as a normative matter, place the defendant on notice of the harm or risk of harm giving rise to the action that he has caused in the particular forum state and therefore anticipate being subjected to suit there. 
defendant's desire to injure the plaintiff in the forum should play a significant role, and some courts apparently have concluded that it does. ${ }^{156}$ That conclusion should be rejected as supported neither by the Supreme Court's decisions nor the relevant considerations of policy.

From a policy standpoint, one initially confronts the difficulty, uncertainty, and cost of appraising the defendant's subjective purpose with reference to the issues of causing harm in the forum state, enjoying the benefits of the laws of that state, or being haled into court there by a particular plaintiff. This is particularly true in the corporate context, where the actions of an incorporeal entity are at issue, and any corporate "purpose" would have to be determined by examining the actions and motivations of a variety of agents acting on the entity's behalf.

The argument against a subjective, purpose-driven test draws support from the law of torts. Under the prevailing view, responsibility for intentional misconduct does not turn on the actor's subjective desires, but rather on whether the actor knows that consequences are certain or substantially certain to result from her actions. ${ }^{157}$ Although the issue of liability for the consequences of one's intentional conduct differs from that of a defendant's geographic amenability to suit, there is no apparent reason for taking a markedly different approach to the kind of intent that makes it fair to subject a defendant to suit in a particular geographic forum.

Under the Supreme Court's current balancing approach to issues of personal jurisdiction, ${ }^{158}$ it is difficult to see why subjective intent or purpose, as opposed to a defendant's awareness to a substantial degree of certainty, should play a determinative role. Convenience of suit is not related to purpose of wrongdoing. A defendant's anticipation of suit and planning to avoid it should be expected and required where significant consequences are substantially certain to result in a particular state. And the interests of the forum and the plaintiff are the same in either event.

Consider, for example, the defendant who ships a bomb by ground carrier through New Jersey for the purpose of injuring an intended victim in New York. If the bomb accidentally explodes in New Jersey and injures the plaintiff there, it seems clear that under any test of personal jurisdiction, the defendant should be subject to suit in New Jersey for the consequences of its acts. The Supreme Court's decisions do not support

156. See supra note 88; supra text accompanying notes 93-102 (citing cases).

157. See RESTATEMENT (SECOND) OF TORTS § 8A cmt. a (1977) (stating that "[i]ntent ... has reference to the consequences of an act rather than the act itself'); $i d$. $\S 8 \mathrm{~A}$ (defining intent as an actor's desire "to cause [certain] consequences . . . or . . . belie[f] that the consequences are substantially certain to result from [his act]"); see also HARPER ET AL., supra note $53, \S 3.3$ ("A result is intended if the act is done for the purpose of accomplishing the result or with knowledge that to a substantial certainty such a result will ensue.") (emphasis added); DAN B. DOBBS, supra note 53, at § 24; RESTATEMENT (SECOND) OF TORTS § 825 (1977) (describing an invasion as "intentional if the actor (a) acts for the purpose of causing it, or (b) knows that it is resulting or is substantially certain to result from his conduct"); Id. $\S 825 \mathrm{cmt}$. c (emphasizing that for an invasion to be intentional it "need not be inspired by malice or ill will on the actor's part toward the other ... [but only requires] that the actor knowingly causes [an invasion] ... without any desire to cause harm"); HARPER ET AL., supra note $53, \S 2.5$ (describing a requirement for trespass as acting "for the purpose of interfering with the chattel or with the knowledge that such interference would result") (emphasis added).

158. See supra text accompanying notes 151-53. 
a stringent test that would focus on the subjective desire or purpose of the defendant to cause harm in a particular state. Moreover, the decisions are not properly interpreted to require that the defendant be substantially certain that harm will result there, provided that the defendant knows that his actions are substantially certain to create a significant risk of harm in the forum. International Shoe itself made no reference to the defendant's intent in its initial articulation of the minimum contacts test. Rather its focus was objective, referring to the nature and quantum of the defendant's activities with respect to the forum and the relationship of the cause of action to those activities. ${ }^{159}$ Hanson and Volkswagen, in which the purposeful availment test was first articulated, were concerned primarily with whether the unilateral act of a third party establishing a contact with the forum could be ascribed to the defendant, and did not suggest that any sort of subjective purpose or desire to cause harm in the forum was required. ${ }^{160}$ Their point, rather, was that the defendant in each of those cases had not itself deliberately engaged in activities that established a connection between the defendant and the forum. In Burger King, the Court sustained jurisdiction on the ground that the defendants deliberately had reached out to establish a business connection in Florida with their franchisor. ${ }^{161}$ The subjective intent or purpose of the defendants to cause injury to their franchisor in Florida was not discussed. The Court stated that the pivotal question was whether the defendant had "purposefully established minimum contacts" with the forum. ${ }^{162}$ Although the Court stated that the "foreseeability of causing injury" in another state was insufficient, it placed the ultimate jurisdictional inquiry in normative and objective terms-whether the defendant should "reasonably anticipate being haled into court" there. ${ }^{163}$

The closest the Court has come in the Burger King line of cases to suggesting that some sort of subjective purpose or intent is required is in Asahi, where Justice O'Connor's plurality opinion for four Justices would have held that the Japanese defendant that sold component valves to a Taiwanese tire tube manufacturer, whose tube was involved in an accident in California, failed to satisfy the purposeful availment requirement because the defendant had not engaged in any act "purposefully directed toward the forum state." 164 The plurality would have required additional conduct indicating an "intent or purpose to serve the market" such as designing the product for the forum, advertising in the forum, establishing channels for customer service in the state, or marketing the product through a distributor serving as a sales agent for that state. ${ }^{165}$ None of these objective factors suggest that some kind of subjective desire or purpose to cause harm in the forum or to injure the plaintiff there is required. Moreover, Justice Brennan's concurring opinion for four Justices clearly would not have required such intent. For them, it was sufficient that the defendant had placed its product in the "stream of commerce" with awareness that the product would

159. See Int'l Shoe Co. v. Washington, 326 U.S. 310 (1945).

160. See supra text accompanying notes 16-17 for discussion of Hanson and text accompanying notes 18-25 for discussion of Volkswagen.

161. Burger King Corp. v. Rudzewitz, 471 U.S. 462, 487 (1985).

162. Id. at 474 (quoting Int'l Shoe Co., 326 U.S. at 316 ).

163. Id. at 474 (quoting World Wide Volkswagen Corp. v. Woodson, 444 U.S. 286, 297 (1980)).

164. Asahi Metal Indus. Co. v. Superior Court, 480 U.S. 102, 112 (1987).

165. Id. at 112; see also supra text accompanying notes 33-36. 
be swept into the state of California. ${ }^{166}$ So long as a participant in this process "is aware that the final product is being marketed in the forum state, the possibility of a lawsuit there could not come as a surprise."167 And, in his lone concurrence in the majority's conclusion that the exercise of jurisdiction in Asahi would be "unreasonable" whether or not minimum contacts were established, Justice Stevens indicated (although he saw no need to reach the question) that whether purposeful availment is found should turn on the objective question of whether the defendant had engaged in a regular course of dealing involving substantial deliveries in California over a period of years. ${ }^{168} \mathrm{He}$ said nothing about an intent or purpose to cause injury in the forum or to injure the plaintiff there.

The Court's initial foray into the field of jurisdiction in intentional tort cases causing effects in the forum state was consistent with this approach. In Keeton v. Hustler Magazine, Inc., the Court focused on whether the defendant had intentionally conducted business in the forum state, not on whether it had a purpose to harm the plaintiff there or even to cause injury there ${ }^{169}$ The Court noted that "[r]espondent's regular circulation of magazines in the forum State is sufficient to support an assertion of jurisdiction in a libel action based on the contents of the magazine." ${ }^{170}$ Further, the Court emphasized that " $[w]$ here, as in this case, respondent Hustler Magazine, Inc., has continuously and deliberately exploited the New Hampshire market, it must reasonably anticipate being haled into court there in a libel action based on the contents of its magazine." ${ }^{\prime 17}$ Keeton thus fell within the main line of the Supreme Court's previous decisions restricting the exercise of personal jurisdiction in suits arising from the conduct of an interstate business to forums in which the defendant had conducted its business giving rise to the claim. Despite the Court's reference to the defendant's "purpose,", 172 there is no indication that any question of subjective motivation or intent to cause harm in the forum was at issue. The relevant intent was simply the defendant's intent to conduct business within the state.

This brings us to Calder, where the Court, in sustaining jurisdiction over the individual Florida defendants in California for their allegedly defamatory article about a California resident, focused explicitly and repeatedly on the defendants' awareness that their article would cause harm to the plaintiff in California. ${ }^{173}$ At first blush, this language is difficult to reconcile with the Court's other personal jurisdiction decisions just reviewed. A purpose to cause harm to a particular plaintiff in the forum seems pivotal to Calder's reasoning and result. It is just this disparity that has led some courts to the apparent conclusion that the Burger King line of cases and Calder establish different, context-specific tests for personal jurisdiction in interstate business cases and intentional tort cases. As discussed in the next Part, however, the cases are reconcilable under a more general test for personal jurisdiction that does not turn on any question of

166. Id. at 117; see also supra text accompanying notes 39-41.

167. Id.

168. Id. at 122; see also supra note 41 .

169. 465 U.S. 770, 781 (1983); see also supra text accompanying notes $42-45$.

170. Id. at $773-74$.

171. Id. at 781 .

172. Id. at 774 .

173. Calder v. Jones, 465 U.S. 783, 789-90 (1984); see also supra text accompanying notes 46-52. 
subjective purpose or intent to cause harm in the forum. ${ }^{174}$ Rather, the cases' holdings are consistent with a general approach to personal jurisdiction that would simply require the defendant to have engaged in conduct that the defendant knows is substantially certain to result in the harm or risk of harm in the forum that gives rise to the plaintiff's claim.

\section{The Case for Basing Personal Jurisdiction on Defendant's Activity Giving Rise to the Action Which the Defendant Knows or Should Know Is Substantially Certain to Have Its Wrongful Impact in the Forum State}

The Supreme Court's treatment of personal jurisdiction issues has been unsatisfactory in at least three important respects. First, the Court, without explanation, has adopted two apparently differing tests for personal jurisdiction without explaining why it has done so or the relationship between the two. Second, the Court has left the lower courts to struggle with the application of one or the other or both of these tests in the increasingly important areas of informational wrongs and Internet activities, even though the tests themselves, which were designed to deal specifically with contractual disputes, product liability claims, and intentional torts having a clear geographic focus, seem ill adapted to this new environment. Third, even though the Court seemingly has made both tests for personal jurisdiction turn on an appraisal of the defendant's purpose or intent, it has failed to explore the many gradations of intent and fault that might be relevant to jurisdictional analysis with the same sort of precision that is customary in other areas of the law. This failure lies at the bottom of the difficulty that the lower courts have experienced in applying traditional jurisdictional analysis to contexts involving consequences not readily connected to a particular geographic location. A refined analysis of the kind of intent that should be relevant to issues of personal jurisdiction involves the consideration of a number of interrelated issues.

\section{Determinative Objects of Awareness}

Putting to one side the degree or level of intent or awareness that should be determinative in the analysis of personal jurisdiction issues, the possibly relevant objects of that awareness include (1) the defendant's awareness of the geographic areas that its conduct might affect, (2) his awareness of the types of claims to which he might be subject to jurisdiction in those fora, and (3) his awareness of the particular plaintiff or plaintiffs who might assert those claims.

The Supreme Court's decisions both in the Burger King line and in Calder quite clearly contemplate that the defendant must have some kind of awareness that his conduct will establish a connection with the geographic area of the forum state. Under Burger King the defendant is required to purposefully direct his activities toward the forum, or to purposefully establish minimum contacts with the forum, or to have

174. Moreover, even accepted at face value, Calder does not require a subjective desire or purpose to harm the plaintiff in the forum state. Instead, the Court focused on the defendants' awareness that their article would harm the plaintiff in California-an approach that would be consistent with basing jurisdictional analysis on the defendant's knowledge to a substantial certainty that its conduct will impact the plaintiff in the forum, regardless of subjective purpose or intent. 
"purposefully avail[ed] itself of the privilege of conducting activities within the forum state." ${ }^{175}$ In Calder, the individual defendants were held to be subject to jurisdiction in California because their "intentional, and allegedly tortious, actions were expressly aimed at California" and because they "knew that the brunt of that injury would be felt by respondent in the State in which she lives and works and in which the National Enquirer has its largest circulation." 176 Lower courts consistently interpret this language as requiring that the defendant act with awareness that its conduct will establish a connection or have a wrongful impact in a particular forum state. A defendant's knowledge that its conduct might have consequences anywhere, without any awareness of the particular state in which those consequences will occur, is insufficient. ${ }^{177}$

As previously discussed, the Supreme Court has suggested only one substantial reason for this particularized geographic awareness requirement, that is, to place the defendant on notice that he might be subject to suit in a particular state and have the opportunity to take steps to avoid or ameliorate that risk by procuring insurance or withdrawing from the state. ${ }^{178}$ The other principal interests relevant to the personal jurisdiction analysis - that of the defendant in avoiding inconvenient litigation, and those of the forum state and the plaintiff in affording and obtaining convenient redress-are at best only weakly related to the geographic particularity of the defendant's awareness, provided that his conduct has in fact caused harm to the plaintiff within the forum state.

A second type of awareness relates to the type of claim that might be asserted by a plaintiff within the forum state. Putting aside the unusual case of general jurisdiction in which a defendant's activities within the forum are so systematic and continuous that it should anticipate suit there on any cause of action no matter whether it is related or unrelated to those contacts, ${ }^{179}$ specific jurisdiction decisions of the Supreme Court and lower courts have required that the claim asserted by the plaintiff in the forum be

175. Burger King Corp. v. Rudzewitz, 471 U.S. 462, 473-75 (1985) (quoting Hanson v. Denckla, 357 U.S. 235, 253 (1958)).

176. Calder, 465 U.S. at $789-90$.

177. See, e.g., ALS Scan, Inc. v. Digital Serv. Consultants, Inc., 293 F.3d 707, 712 (4th Cir. 2002) (posting information on the Internet cannot subject the defendant to jurisdiction wherever it can be accessed, because such information can be accessed in every state); GTE New Media Serv., Inc. v. Bellsouth Corp., 199 F.3d 1343, 1349-50 (D.C. Cir. 2000) (jurisdiction cannot be based on ability to access a passive Web site in the forum state because this would subject the defendant in Internet cases to jurisdiction anywhere in the country); Cybersell, Inc. v. Cybersell, Inc., $130 \mathrm{~F} .3 \mathrm{~d}$ 414, 417-18, 420 (9th Cir. 1997) (following cases rejecting jurisdiction based on ability to access a "passive" Web site worldwide).

178. World Wide Volkswagen Corp. v. Woodson, 444 U.S. 286, 297 (1980).

179. Helicopteros Nacionales de Colombia v. Hall, 466 U.S. 408, 415-16 (1984) (explaining that even though the "respondents' claims against Helicol did not 'arise out of,' and are not related to, Helicol's activities within Texas," the Court must still "explore the nature of Helicol's contacts with the State of Texas to determine whether they constitute the kind of continuous and systematic general business contacts the Court found to exist in Perkins"); Perkins v. Benguet Consol. Mining Co., 342 U.S. 437, 438 (1952) (sustaining the exercise of general jurisdiction over a Philippine corporation by an Ohio court because the corporation carried on continuous and systematic business in Ohio). 
related to the defendant's activities there. ${ }^{180}$ There is more to this requirement than some elemental notion of fairness. Rather, the relationship requirement once again is calculated to place the defendant on notice of the scope of the risk that its conduct has created with respect to a particular jurisdiction. To permit the defendant to be sued by a plaintiff on a claim that has nothing to do with the defendant's activities in or with respect to the forum would make the bedrock notice element meaningless. All that the defendant would know or anticipate is that any deliberate activity of any kind establishing some connection with the forum would potentially expose him to suit there by any plaintiff on any claim that might arise from his activities anywhere. The risk would be unknown and unquantifiable. A requirement that the defendant insure against such a risk or cease his activities with respect to the forum to avoid harms that have nothing to do with his conduct there would expand the authority of a state beyond the scope of any legitimate sovereign interest.

Finally, the personal jurisdiction issue might be thought to turn on the defendant's required degree of awareness of the identity of the particular plaintiff or plaintiffs who might assert claims related to his activities with respect to the forum state. That degree of awareness, however, clearly is not required by the "transaction of business" cases falling in the Volkswagen-Burger King line. In product liability suits such as those involved in Volkswagen and $A$ sahi, for example, the identity of the particular person or persons who may be injured by the defendant's product is unknown, making it impossible for the defendant to be aware of the identity of a potential plaintiff.

In this respect, cases following Burger King superficially appear to be inconsistent with Calder and its progeny. Calder placed heavy focus on the fact that the individual defendants knew that the brunt of the harm caused by their article would be felt by the plaintiff in California where she lived and worked and emphasized that they were "primary participants in an alleged wrongdoing intentionally directed at a California resident." ${ }^{181}$ Subsequent cases in the Calder line frequently have relied on defendant's knowledge or lack of knowledge of the plaintiff's residence in a particular jurisdiction in upholding ${ }^{182}$ or denying ${ }^{183}$ jurisdiction. The most extreme example of this was in

180. Helicopteros Nacionales de Colombia, 466 U.S. at 414 n.8; Ruston Gas Turbines, Inc. v. Donaldson Co., 9 F.3d 415, 418-19 (5th Cir. 1993) ("A state exercises 'specific jurisdiction' over a non-resident defendant when the lawsuit arises from or relates to the defendant's contact with the forum state.").

181. Calder, 465 U.S. at 790.

182. Bancroft \& Masters, Inc. v. Augusta Nat'l, Inc., 223 F.3d 1082, 1087-88 (9th Cir. 2000) (upholding jurisdiction because defendant individually targeted a plaintiff whom the defendant knew was a resident of the forum state); Panavision Int'l, L.P. v. Toeppen, 141 F.3d 1316, 1321-22 (9th Cir. 1998) (finding that jurisdiction was proper where defendant knew that plaintiff would suffer harm in California where its principal place of business was located); Gordy v. Daily News, L.P., 95 F.3d 829, 833 (9th Cir. 1996) (upholding jurisdiction where despite small distribution of newspapers, defendant intentionally wrote and directed an article at a resident of the forum state).

183. Revell v. Lidov, 317 F.3d 467, 475 (5th Cir. 2002) (failing to find jurisdiction over defendant under Calder or Zippo because Texas was not the focal point of the article and defendant did not know that the plaintiff resided in Texas); Chaiken v. VV Publ'g Corp., 119 F.3d 1018, 1029 (2d Cir. 1997) (rejecting personal jurisdiction in Massachusetts under Calder in a defamation case since the publisher had no reason to believe that the plaintiffs continued to reside in Massachusetts); Pavlovich v. Superior Ct., 58 P.3d 2, 10-12 (Cal. 2002) (failing to 
Pavlovich where a closely divided California Supreme Court rejected jurisdiction over a suit by the licensor of DVD encryption technology that the Texas defendant was alleged to have misappropriated by posting a program to enable the copying of DVDs on his Web site. ${ }^{184}$ Despite arguments that the defendant was aware that his conduct would have a significant impact on the motion picture and computer industries centered in California, the majority rejected jurisdiction, relying heavily on the fact that the defendant did not know that the plaintiff licensing entity was headquartered in California until after the lawsuit was filed. ${ }^{185}$

What explains this divergence between the interstate business cases following Burger King and the intentional tort cases following Calder? Why is knowledge of the plaintiff's identity and location deemed important by some courts in the latter context but not the former? Identifying the source of this apparent inconsistency may cast light on the reason why differing tests for personal jurisdiction have emerged in business activity and intentional tort cases. It may also help to identify an underlying, unifying theme.

We suggest that in both kinds of cases, the Supreme Court's underlying concem has been whether the defendant reasonably should anticipate the impact of his activities (and the consequent risk of suit) in a particular geographic jurisdiction. ${ }^{186}$ In business activity cases, the Court has said that a defendant who purposefully avails himself of the privilege of conducting business activities in or directed to obtaining sales in a particular state reasonably should anticipate that tortious or contractual injuries arising from those activities will subject him to suit there ${ }^{187}$ No finely tuned calculus of the precise magnitude of the risk turning on the identity of the particular plaintiff or plaintiffs who might be injured in the state is required.

exercise jurisdiction because defendant did not know that the plaintiff's principal place of business was in California and defendant's general knowledge that his actions "may harm certain industries centered in California-i.e., the motion picture, computer, and consumer electronics industries" could not alone satisfy the effects test).

184. Pavlovich, 58 P.3d at 10-12.

185. Id. at 11-12. The court noted that "[b]ecause Pavlovich could not have known that his tortious conduct would harm DVD CCA in California when the misappropriated code was first posted, his knowledge of the existence of a licensing entity cannot establish express aiming at California." Id. at 11. The court rejected the argument that the location of licensees in the consumer electronics and computer industries centered in California was sufficient to show that Pavlovich knew that his posting would cause harm to them there on the ground that " $[t]$ he record ... indicate[d] that Pavlovich did not know that any of DVD CCA's licensees resided in California. At most, the record establishe[d] that Pavlovich should have guessed that these licensees resided in California." Id. at 12. By contrast, the lack of knowledge that the plaintiff licensing entity was located there was irrelevant in the dissent's view. "When a foreign defendant, by intentional conduct directed toward the forum, establishes the necessary minimum contacts with that jurisdiction, he or she may be exposed to litigation there for any 'controversy [that] is related to or "arises out of' [those] contacts ...." The plaintiff need not be the exact person or entity toward whom the defendant's conduct was directed." Id. at 22 (Baxter, J., dissenting) (quoting Vons Cos. v. Seabest Foods, Inc., 926 P.2d 1085 (Cal. 1996)) (emphasis in original) (citations omitted).

186. See Jennings v. AC Hydraulic A/S, 383 F.3d 546, 551 (7th Cir. 2004) (interpreting the Supreme Court's decisions as requiring the defendant to establish minimum contacts with "the particular state in which the court sits").

187. See Burger King Corp. v. Rudzewitz, 471 U.S. 462 (1985). 
Many tort cases not arising from the conduct of interstate business may be treated similarly. Because the defendant has engaged in wrongful conduct that he knows to a substantial certainty will cause injury or create an actionable risk of harm in the forum state, he should be required to anticipate the geographic sweep of the impact of his conduct and take action to avoid the risk that his actions create. For example, where a defendant deliberately sends a bomb from one state into another knowing that it may explode and cause serious injury there, the geographic scope of his tortious activities is clear. There is and should be no requirement that the defendant know the identity of the particular plaintiff or plaintiffs who actually suffer the injury there. The defendant's deliberate conduct with respect to the forum that a reasonable person would know is substantially certain to cause injury there or to create a risk of harm there should be sufficient to subject it to jurisdiction for the ensuing injuries when they occur. Such jurisdiction should not be limited to intentional torts, such as assault, but should extend to reckless or negligent injuries as well. The key factor is not whether the defendant's conduct should be treated as intentional for the purpose of determining his substantive liability in tort, but whether his conduct with respect to the particular jurisdiction is such that he should be required to anticipate suit there for the consequences of those actions.

In some tort cases, however, the particular geographic scope of the defendant's tortious activity and its impact may not be apparent. Where a defendant publishes a defamatory article, the tortious impact of that activity occurs where the plaintiff's reputation has been injured, which turns on where his reputation is established and known, which most often will turn on where the plaintiff lives and works, or where his reputation has otherwise been established. ${ }^{188}$ In such cases, unlike those involving sending a bomb or other dangerous instrumentality into a particular state, the fact that the defendant has engaged in tortious activity does not automatically place him on notice of the geographic scope of the wrongful impact of that activity. It is precisely in such cases-those following the Calder line-that courts have emphasized the defendant's awareness that the plaintiff's residence or business activities are located in the forum state. Without such awareness, the defendant is not properly charged with notice that his activities will have their impact there, exposing him to a risk of suit. Thus, despite the apparently differing articulations of the jurisdictional standard in interstate business cases illustrated by Burger King and Volkswagen, on the one hand, and the extraterritorial tort cases illustrated by Calder, on the other, those decisions are united by an underlying premise: a basic precondition for the exercise of jurisdiction over a nonresident defendant is the requirement that the defendant be on notice that the harm or risk of harm created by his activities that gives rise to the plaintiff's action is substantially certain to occur in the forum state.

188. See, e.g., Calder v. Jones, 465 U.S. 783, 788-90 (1984) ("The allegedly libelous story concerned the California activities of a California resident ... . The article was drawn from California sources, and the brunt of the harm, in terms both of respondent's emotional distress and the injury to her professional reputation, was suffered in California."); Faulkner v. Ark. Children's Hosp., 69 S.W.3d 393, 402 (Ark. 2002) (explaining that under Arkansas law a plaintiff must demonstrate that she was defamed by a false statement of fact which damaged her and harmed her reputation); Ellis v. Price, 990 S.W.2d 543, 547 (Ark. 1999) (same); Gobin v. Globe Publ'g Co., 649 P.2d 1239, 1243 (Kan. 1982) (noting that "[d]efamation actions in Kansas" require evidence of "injury to reputation" in the community). 


\section{Degrees of Awareness}

If, as we suggest, the defendant's awareness of the geographic scope of the allegedly wrongful impact of his activities should provide the touchstone for personal jurisdiction analysis, the question remains what degree of awareness should be required. One of the peculiarities of the Supreme Court's treatment of personal jurisdiction issues in both the Burger King line and Calder has been that the relevant jurisdictional test has been phrased in terms of the defendant's purpose or intent, without any clear analysis of precisely what kind of intent is required. This failure should be contrasted with the careful analysis of intent typical in tort law, with fine distinctions drawn between degrees of intent, ${ }^{189}$ ranging from purpose, to knowledge to a substantial certainty, ${ }^{190}$ to recklessness (itself of two types), ${ }^{191}$ to negligence, ${ }^{192}$ and with equally careful attention to the objects of that intent.

189. In tort law,

[i]f the actor knows that the consequences are certain, or substantially certain, to result from his act, and still goes ahead, he is treated by the law as if he had in fact desired to produce the result. As the probability that the consequences will follow decreases, and becomes less than substantial certainty, the actor's conduct loses the character of intent, and becomes mere recklessness.

RESTATEMENT (SECOND) OF TORTS $§ 8 A \mathrm{cmt} . \mathrm{b}$ (1977) (emphasis added).

190. The Restatement (Second) of Torts defines "intent" in relation to a battery as an act "done for the purpose of bringing about a harmful or offensive contact ... or with knowledge that such a result will, to a substantial certainty, be produced by his act." $I d . \S 18 \mathrm{cmt}$. e (emphasis added).

191. Recklessness is also "distinguishable both from intent and from negligence" in that it requires conduct undertaken by an actor conscious of "a high degree of risk or a risk of very serious harm." DoBBS, supra note 53, at $§ 27$; see also Kenneth W. Simmons, Rethinking Mental States, 72 B.U. L. REV. 463, 475 n.50 (1992) ("The Second Restatement seems to distinguish between recklessness as a ground for tort liability ('reckless disregard of the safety of another,' which can be shown by an objective test, Restatement (Second) of Torts $\S 500$ ), and as a ground for punitive damages ('outrageous' conduct that shows 'reckless indifference to the rights of others,' Restatement (Second) of Torts $\S 908$ ).").

Illustrations 1 and 2 to Restatement $\S 8 \mathrm{~A}$, distinguish an "intentional tort" from a "reckless action" as follows:

1. $A$ throws a bomb into $B$ 's office for the purpose of killing $B$. $A$ knows that $C$, $B$ 's stenographer, is in the office. $A$ has no desire to injure $C$, but knows that his act is substantially certain to do so. $C$ is injured by the explosion. $A$ is subject to liability to $C$ for an intentional tort.

2. On a curve in a narrow highway $A$, without any desire to injure $B$, or belief that he is substantially certain to do so, recklessly drives his automobile in an attempt to pass $B$ 's car. As a result of this recklessness, $A$ crashes into $B$ 's car injuring $B$. $A$ is subject to liability to $B$ for his reckless conduct, but is not liable to $B$ for any intentional tort.

RESTATEMENT (SECOND) OF TORTS $\$ 8 A$ illus. $1 \& 2$.

192. Negligence emphasizes risk "as it would be perceived by a reasonable person," not the defendant's purpose or the certainty required to show intent. DoBBS, supra note 53 , at $\S \S 26$, 116. 
The Burger King test focuses on the defendant's purposeful availment or some equivalent purposeful act, ${ }^{193}$ but, for the reasons previously explained, this terminology should not be understood to refer to a defendant's subjective purpose or desire to cause injury in the forum. At the very most, it should be understood to refer to the defendant's deliberately undertaken activities that the defendant knows to a substantial certainty will have a geographic scope or impact that embraces the forum state. Given such knowledge, it is fair to require the defendant to anticipate suit in the forum state with respect to claims arising from those activities, and to take steps to avoid or ameliorate that risk.

Similarly, the Calder test, which requires express aiming or targeting of the plaintiff in intentional tort cases, ${ }^{194}$ should at the most be interpreted to require the defendant to have committed a tortious act knowing to a substantial certainty that it will have its impact on the plaintiff in the forum state. Even this requirement goes too far, however, by confounding the kind of intent necessary to hold the defendant liable to the plaintiff with the kind of intent that should suffice to subject the defendant to personal jurisdiction in the forum state. For jurisdictional purposes, the key question should not concern intent to injure the plaintiff, but the defendant's awareness of the geographic scope of his activities and their impact. Thus, knowledge to a substantial certainty that the defendant's activities will have their claimed wrongful impact (including the creation of an actionable risk of harm) in a particular state should be sufficient to place the defendant on notice that he may be subjected to suit there if those consequences ensue. Consider, for example, a defendant that deliberately places a bomb on a train running from Philadelphia to New York with a timing device set to cause the bomb to explode upon arrival in Grand Central Station. The fact that the bomb, as a result of reckless or negligent miscalculation, instead explodes in New Jersey and causes injury there should be sufficient to sustain jurisdiction in New Jersey even though the defendant had no desire to cause injury there, and did not know to a substantial certainty that such injury would occur. The critical factor is that the defendant knew that the geographic scope of the risk created by his activity was substantially certain to include New Jersey, as well as Pennsylvania and New York.

Indeed, we submit that this "at the most" interpretation of the Supreme Court's requirement that the defendant have acted with purpose or intent related to the forum state itself may require too much. ${ }^{195}$ In the previous example, assume that a particularly unaware defendant, having been a poor student of geography in her academic days, did not know to a substantial certainty that a bomb placed on a train traveling between Philadelphia and New York would travel through New Jersey. What difference can that make? Surely the defendant should be required to be aware of things that reasonable people in the defendant's position should know, and to take steps to avoid or ameliorate the risk of harm that they have created. ${ }^{196}$ Viewed in this way, the kind of

193. Burger King Corp. v. Rudzewicz, 471 U.S. 462, 475 (1985).

194. Calder v. Jones, 465 U.S. 783,789 (1984).

195. Other commentators have critiqued the fact that courts have permitted jurisdiction based on whether the plaintiff demonstrated "knowledge" or "specific intent" in targeting the specific forum. See, e.g., Stein, Regulatory Precision, supra note 9, at 423-24.

196. This approach comports with the objective "reasonable man" standard applied in the law of torts. The Restatement defines a "reasonable man" as a person "exercising those qualities of attention, knowledge, intelligence, and judgment which society requires of its members for 
intent relevant to personal jurisdiction analysis may be more appropriately viewed as consisting of recklessness regarding the geographic scope of the risk of harm that the defendant's wrongful conduct has created. ${ }^{197}$

This approach would be congruent with the underlying policies identified by the Supreme Court as relevant to personal jurisdiction analysis. The Court has imposed the core purposeful availment or express aiming or targeting requirements of Burger King and Calder to ensure that the defendant will be in a position to reasonably anticipate suit in the forum state. A requirement that the defendant deliberately have engaged in activities that a reasonable person would anticipate to be substantially certain to have an impact or create an actionable risk of harm in the forum state should be sufficient to serve that end. The balance of the other key interests at stake-that of the forum state in affording a convenient forum to its residents, that of the plaintiff in obtaining relief, and that of the defendant in avoiding inconvenient litigation-is unaffected by whether the defendant has acted with actual awareness that the geographic scope of the impact of his conduct would include the forum state, or only should have been aware that it would. Some decisions in the Calder and Burger King lines implicitly appear to have recognized this fact, and to have focused on the consequences of which the defendant should have been aware, rather than simply on those of which it was in fact aware. ${ }^{198}$

Nevertheless, the Supreme Court, in Volkswagen and subsequent decisionsparticularly in Calder itself ${ }^{99}$-might be argued to have explicitly rejected just such an approach to personal jurisdiction, to the extent that it is based on the foreseeable geographic impact of the defendant's actions, as opposed to a defendant's actual purpose or awareness of the geographic consequences of his conduct. ${ }^{200}$ In Volkswagen, the Court rejected the assertion of personal jurisdiction in Oklahoma over the New York wholesaler and retailer of an automobile, finding that the foreseeability that the New York purchaser of the automobile might drive it to other states where it might cause an injury should not subject the defendants to suit in those states. The

the protection of their own interests and the interests of others." RESTATEMENT (SECOND) OF TORTs $\S 283 \mathrm{cmt}$. b (1977). Further, the "standard which the community demands must be an objective and external one, rather than that of the individual judgment, good or bad, of the particular individual." $I d . \S 283 \mathrm{cmt}$. c. "The reasonable person ... standard is "very largely but not entirely objective." DOBBS, supra note 53, at $\$ 118$.

197. See W. Page Keeton, Dan B. Dobbs, Robert E. Keeton \& David G. Queen, Prosser AND KEETON ON TORTS $§ 34$, at 213 (5th ed. 1984) (classifying an actor's conduct as reckless where "the actor has intentionally done an act of an unreasonable character in disregard of a known or obvious risk that was so great as to make it highly probable that harm would follow").

198. See supra text accompanying note 90 .

199. See Calder, 465 U.S. at 789 (stating that the fact that defendants might have foreseen that their publisher might circulate their article in California where it might have an effect was, standing alone, insufficient to establish jurisdiction).

200. See World-Wide Volkswagen Corp. v. Woodson, 444 U.S. 286, 295-98 (1980). The federal courts of appeals have applied this principle, finding that foreseeability alone is insufficient to establish personal jurisdiction. See OMI Holdings, Inc. v. Royal Ins. Co. of Canada, 149 F.3d 1086, 1094 (10th Cir. 1998) (noting that foreseeability is not sufficient to establish personal jurisdiction over the defendant); Mountaire Feeds, Inc. v. Agro Impex, S.A., 677 F.2d 651, 656 (8th Cir. 1982) (requiring more than foreseeability to exercise jurisdiction over a Panamanian company in a contract dispute). 
Court stated that "“foreseeability' alone has never been a sufficient benchmark for personal jurisdiction under the Due Process Clause."201

But Volkswagen should not be interpreted to make irrelevant an evaluation of what the defendant should know regarding the geographic scope of the effects of his actions. The Court itself identified the ultimate touchstone of personal jurisdiction analysis as whether the "defendant's conduct and connection with the forum State are such that he reasonably should anticipate being haled into court there," 202 thus focusing on what the defendant should anticipate, rather than what it did. The Court's rejection of jurisdiction in Volkswagen turned on the conclusion that the defendants did not regularly serve the Oklahoma market "directly or indirectly,"203 and could not anticipate suit there based on the "unilateral" act of a customer, or the "isolated" and "fortuitous" circumstance that one of their customers might take a single automobile that they purchased in New York to another state where it would be involved in an accident. ${ }^{204}$ The Court's focus was to ensure a "degree of predictability" in the legal system, ${ }^{205}$ a concern that should be viewed in objective rather than subjective terms. In later decisions the Court has emphasized that the focus of its jurisdictional restrictions based on purpose, and excluding the assertion of jurisdiction based on foreseeability alone, is to screen out cases in which the connection of the defendant's activities with the particular jurisdiction is "'random,' 'fortuitous,' or 'attenuated.",206

Where the impact of the defendant's conduct in the forum state is regular and predictable, the Court has evidenced considerably more difficulty in determining whether the purposeful availment component of the Burger King test has been satisfied. As previously discussed, in Asahi Metal Industry Co. v. Superior Court, ${ }^{207}$ the Court divided four-four-one on whether the Japanese supplier of valve assemblies, which were incorporated into tire tubes by a Taiwanese company and subsequently distributed by that company in Califormia, had purposefully availed itself of the benefits of doing business in California. Justice O'Connor's plurality opinion, joined by three other Justices, would have required something more than the defendant's awareness that its valve assembly might be swept into the state in the "stream of commerce" and cause an injury there. ${ }^{208}$ Rather, she argued that Asahi must have engaged in some act "purposefully directed toward the forum state," such as designing the product for the market, advertising or providing customer service there, or enlisting a distributor to serve the state. ${ }^{209}$ By contrast, Justice Brennan, joined by three other Justices, concluded that Asahi's "regular and extensive sales of component parts to a manufacturer it knew was making regular sales of the final product in California" should suffice. ${ }^{210}$

201. World-Wide Volkswagen Corp., 444 U.S. at 295.

202. Id. at 297 (emphasis added).

203. Id.

204. Id. at $295,298$.

205. Id. at 297.

206. Burger King Corp. v. Rudzewicz, 471 U.S. 462, 480 (1985).

207. 480 U.S. 102 (1987).

208. See supra text accompanying notes 33-36.

209. Asahi Metal Indus. Co., 480 U.S. at 112 (plurality opinion).

210. Id. at 121 (Brennan, J., dissenting). 
The stream of commerce refers not to unpredictable currents or eddies, but to the regular and anticipated flow of products from manufacture to distribution to retail sale. As long as a participant in this process is aware that the final product is being marketed in the forum State, the possibility of a lawsuit there cannot come as a surprise. $^{211}$

Although both opinions appear on their face to focus on a defendant's awareness of the geographic scope and impact of its activities, Justice O'Connor's approach could be argued to require some desire or purpose on the part of the defendant to serve the particular forum state, whereas Justice Brennan's approach is more focused on the defendant's awareness of the ultimate scope and consequences of its actions, regardless of any such purpose or intent. This latter approach, in turn, shades into that advocated by Justice Stevens, who focused on purely objective factors indicating that the defendant should be on notice that its activities were having significant and predictable consequences in the forum and should anticipate the possibility of suit there. Justice Stevens found no "unwavering line" between " mere awareness" that a component will find its way into the forum State and 'purposeful availment' of the forum's market.",212

Just as Justice Stevens recognized that no unwavering line divides purpose from mere awareness, so too no sharp line should be drawn, in personal jurisdiction analysis, between a defendant's actual awareness and what the defendant should know about the geographic scope of the impact of his conduct. Ultimately, the question is whether the defendant should reasonably anticipate suit in the forum, not whether he did so. An approach predicated solely on a particular defendant's actual awareness of the geographic scope of his activities and their impact would encourage a "head in the sand" attitude by persons who should anticipate the possibility of suit in a remote jurisdiction based on the regular and significant impact of their activities there. It could also breed time-consuming and inconclusive litigation on a preliminary issue over what a defendant actually did know, as opposed to what he should have known.

\section{Superseding Causes}

Nevertheless, the Supreme Court's concern that a defendant not be exposed to suit in a remote jurisdiction based on random, attenuated, or unpredictable events, or the unilateral acts of third parties that are disconnected from the geographic scope of the defendant's own activities, is legitimate. The appropriate response to that concern lies neither in making subjective purpose the sine qua non of personal jurisdiction analysis, nor in making the foreseeability of wrongful effects in the forum state irrelevant. In this regard, the extensive consideration given by the law of torts to the question of whether the intervening acts of a third party should constitute a superseding cause of the defendant's wrongful conduct that relieves the defendant of substantive responsibility for its actions again is instructive. In this instance, however, the relevant issue is not ultimate liability under the substantive law, but rather the scope of geographic responsibility that a defendant should bear for his actions. In both negligent and intentional torts, the defendant's actions must be found to be the proximate cause of the

211. Id. at 117 (Brennan, J., dissenting) (emphasis added).

212. Id. at 122 (Stevens, J., concurring in part and in the judgment). 
plaintiff's injuries. ${ }^{213}$ An intervening cause, such as the act of a third party or force of nature, does not necessarily prevent recovery from the defendant. ${ }^{214}$ However, an intervening cause may constitute a superseding cause ${ }^{215}$ that relieves the original actor from responsibility in certain circumstances. ${ }^{216}$ Courts determine whether an intervening cause should be deemed a superseding cause through a foreseeability inquiry. ${ }^{217}$ This inquiry focuses on such factors as whether the consequences appear to be a novel or extraordinary result of the defendant's action, whether it operates independently of the situation created by the conduct of the original actor, whether the act of a third party is involved, and, if so, whether that act itself is wrongful, and other factors, ${ }^{218}$ such as the geographic and temporal remoteness of the harm. ${ }^{219}$ The physical

213. Proximate cause and cause in fact are required to prevail in a negligence or intentional tort action. RESTATEMENT (SECOND) OF TORTS $\S 430$ (2003) (referring to the concept of proximate cause as "legal cause"); DoBBS, supra note $53, \S 180$. Although this rule is often "stated in terms of the actor's negligent conduct," proximate cause is also required for intentional torts. RESTATEMENT (SECOND) OF TORTS $§ 430$ (2003). "The superseding cause limitation applies to all tort actions, including the intentional torts." Richard W. Wright, The Grounds and Extent of Legal Responsibility, 40 SAN DIEGO L. REV. 1425, 1478 (2003).

214. An intervening cause is when a defendant creates "risks of harm, but the immediate trigger of harm is another person or force of nature" and does not bar recovery. DOBBS, supra note 53, §§ 186, 180; RESTATEMENT (SECOND) OF TORTS $\$ 430$ (2003) (noting that a negligent actor only needs to "be a legal cause of the harm" not "the" legal cause "as meaning the sole and even the predominant cause"); Wright, supra note 213 , at 1468 ("It is usually stated that, to be an intervening cause, the conduct or event at issue must have temporally intervened between the occurrence of the defendant's tortious conduct and the plaintiff's injury.") (emphasis in original).

215. In general, an intervening cause does not become a superseding cause of a defendant's negligence if it "reflects the same general kind of risk which rendered the defendant negligent." DoBBS, supra note 53, $\S 186$. RESTATEMENT (SECOND) OF TORTS $\S 440$ (2003) (defining a superseding cause as "an act of a third person or other force which by its intervention prevents the actor from being liable for harm to another which his antecedent negligence is a substantial factor in bringing about").

216. If an intervening cause "is the only proximate cause because it is the efficient or immediate cause, then the intervening cause will be called superseding cause and the [original] defendant will not be liable." DoBBS, supra note 53, § 186. Wright, supra note 213, at 1468 ("A superseding cause is an actual cause of the plaintiff's injury that (1) intervened between the defendant's tortious conduct and the plaintiff's injury, (2) was a necessary (but-for) cause of the plaintiff's injury, and (3) was highly unexpected. The second and third factors are the critical ones.").

217. DoBBs, supra note 53, §§ 186-87; see also Wright, supra note 213 at 1468 ("The defendant should not be liable, even though her tortious conduct contributed to the plaintiff's injury, if the injury occurred only because of the intervention of some highly unexpected ('extraordinary' or 'highly extraordinary') condition that disrupted and radically shifted the flow of events. On the other hand, there would be little reason (at least as a matter of justice) to absolve the defendant of liability because of the existence of an intervening cause, no matter how unexpected the intervention was, if the injury would have occurred as a result of the defendant's tortious conduct regardless of the intervention.").

218. Several factors are important in determining whether an intervening cause is a superseding cause. These include whether (1) "its intervention brings about harm different in kind from that which would otherwise have resulted from the actor's negligence"; (2) the 
remoteness of the effects of a defendant's actions does not itself bar recovery, provided that they should be readily anticipated by the defendant. ${ }^{220}$

In the context of the defendant's geographic responsibility for the consequences of its actions, this kind of proximate cause analysis would screen out remote, attenuated, episodic, and unpredictable geographic harms that were not reasonable foreseeable by the defendant. At the same time, it would sustain personal jurisdiction for specific geographic effects that were the natural and predictable consequences of the defendant's actions and that the defendant therefore reasonably should have anticipated. Where the unilateral acts of a consumer over which the defendant has no control and which he cannot predict, such as the act of the purchaser of an automobile in driving it to a remote state in Volkswagen, are at issue, an analysis based on transposition of concepts of proximate and superseding cause-appropriately molded in light of the policies relevant to the scope of geographic responsibility for the consequences on one's actions rather than the imposition of substantive liability in tort-would reject the exercise of jurisdiction. By contrast, in cases such as Asahi, where the maker of a component part supplies it to an intermediate manufacturer that it knows or should know will incorporate it into a commercial product that will be sold in the forum state, generating profits that ultimately redound to the benefit of the component supplier, the intervening acts of the manufacturer are not random, attenuated, unusual, or unpredictable. In such circumstances, an approach such as that of Justice O'Connor in Asahi, which rejects jurisdiction in all cases on the ground that the maker of the component had not itself taken action directly to market its product in the forum state, takes too restrictive a view of the scope of geographic responsibility that the defendant should bear for its actions. Of course, jurisdiction should not be sustained in such cases in all circumstances. Rather, once the geographic scope of the

consequences appear "extraordinary rather than normal in view of the circumstances existing at the time of its operation"; (3) "the intervening force is operating independently of any situation created by the actor's negligence, or on the other hand, is or is not a normal result of such a situation"; (4) "the intervening force is due to a third person's act or to his failure to act"; (5) "the intervening force is due to an act of a third person which is wrongful toward the other and as such subjects the third person to liability to him"; (6) "the degree of culpability of a wrongful act of a third person which sets the intervening force in motion." RESTATEMENT (SECOND) OF TORTS $\S 442$ (2003).

219. DoBBS, supra note $53, \S 180$. In determining remoteness in time and space, courts consider that the greater the distance between the action and the injury, the more likely that other actions intervened. See Palsgraf v. Long Island R.R. Co., 162 N.E. 99, 104 (N.Y. 1928) (Andrews, J., dissenting) ("Clearly we must so consider, for the greater the distance either in time or space, the more surely do other causes intervene to affect the result."); Bird v. St. Paul Fire \& Marine Ins. Co., 86 N.E. 120 (N.Y. 1918) (considering remoteness in time and space).

220. Some courts have found that remoteness in time or space is important in "determining whether the defendant has been a substantial factor in causing the harm" but that "physical remoteness should of itself [not] bar recovery." Jacobs v. Martz, 166 N.W.2d 303, 305-06 (Mich. Ct. App. 1968); see also Ballard v. Uribe, 715 P.2d 624, 629 n.6 (Cal. 1986); Osborn v. City of Whittier, 230 P.2d 132, 136 (Cal. Dist. Ct. App. 1951) (noting that "[p]roximity in point of time or space . . . is of no importance except as it may afford evidence for or against proximity of causation"); KEETON ET AL., supra note 197, § 43, at 283 (5th ed. 1984) ("The defendant who sets a bomb which explodes ten years later, or mails a box of poisoned chocolates from California to Delaware, has caused the result, and should obviously bear the consequences."). 
impact of its actions that the defendant should anticipate is established, the overarching due process requirement of the reasonableness of the exercise of jurisdiction under all of the circumstances must be satisfied as well. ${ }^{221}$ The Supreme Court majority in Asahi appropriately rejected jurisdiction on this ground, rather than because the foundation purposeful availment requirement was not met.

This analysis may help to explain the result in Calder, in which the Supreme Court sustained jurisdiction over the individual defendants in California despite their argument that they were not responsible for the publisher's decision to circulate their allegedly defamatory article in California, even though they might have foreseen that it would have its harmful effects there. ${ }^{222}$ The Court rejected the contention that the defendants were like a welder who worked on a boiler in Florida that later exploded in California on the ground that, unlike the welder, the defendants' acts were expressly aimed at California where the plaintiff lived and worked. Calder should not be distinguished from the hypothetical welding case on the basis of the defendants' subjective purpose or intent, however, nor on the ground that foreseeability alone is not enough. Rather, in the welding hypothetical, the defendant would have had no reason to predict that the defective boiler would cause harm in any particular state, and no reason to predict that his employer's intervening act would send it there. By contrast, in Calder, the defendants clearly could predict that their defamatory article would be circulated in California and have its wrongful impact there, in view of the substantial certainty that their employer would circulate the article there and that their active participation in the chain of events that predictably led to that result. They had no basis for arguing that their employer's actions were an extraordinary or unexpected intervening cause that should relieve them of geographic responsibility for the effects of their actions.

But what if the welder, although acting negligently rather than intentionally as in Calder, knew in fact that all of his employer's boilers were sold in California? The logic of our argument suggests that the defendant's intent or awareness with respect to the geographic impact of its actions, rather than his intent or awareness in committing the underlying tort, should control. This conclusion might draw support from the Supreme Court's decisions involving the conduct of interstate business operations, in which a foreign defendant that has purposefully directed his activities toward the forum is subject to jurisdiction there for negligence and strict liability claims, as well as for intentional torts. Such an argument would draw additional support from Calder itself. Although courts commonly view that decision as applicable only to intentional torts targeted at the plaintiff in the forum state, the tort of defamation sometimes imposes strict liability for utterances that the defendant had no reason to believe were defamatory towards the plaintiff. $^{223}$

But Calder gives no indication that it was intended to extend so far. In cases involving purely negligent conduct, it is likely that the intervening acts of the welder's employer in determining where to circulate the defective boiler would be held to constitute a superseding cause of the geographic impact of the welder's negligent conduct. ${ }^{224}$ If, on the other hand, the welder had deliberately installed a defective valve

221. See supra text accompanying notes 151-53.

222. Calder v. Jones, 465 U.S. 783,789 (1984).

223. KEETON ET AL., supra note 197, at 808.

224. See supra text accompanying notes $213-21$. 
on a boiler knowing that it would explode when used, and additionally knew or should have known that the boiler was destined for use in California, no reason is apparent why the welder should be relieved of geographic responsibility for the consequences of his actions there.

Of course, this approach inevitably would involve the difficult issues of judgment and uncertainties that infect proximate cause analysis generally. But to assume that making such ambiguous concepts as "purposeful availment," "express aiming," and "targeting" the touchstone of personal jurisdiction analysis has eliminated those uncertainties would be incorrect, as illustrated by the many difficulties courts have faced in interpreting and applying those concepts in the cases previously reviewed. ${ }^{225}$ Those difficulties have been particularly evident as courts have struggled to extend those tests to new contexts such as informational wrongs and Internet activities to which they were not addressed. In this respect, the Supreme Court's foundation decision in International Shoe was prescient in its failure to focus on the defendant's intent, or to adopt a rigid or formulaic approach to minimum contacts analysis. Rather, the Court recognized the inevitable shades of gray, degrees of responsibility, and issues of judgment that do and must attend the determination of the appropriate geographic sweep of a state's sovereign power to reach actors located in other states-and the corresponding geographic scope of responsibility that those actors should bear for their conduct. In providing guidance on those issues, the Court focused not on intent, but rather on the nature and quantum of the defendant's actions with respect to the forum state and the relationship of those actions to the cause of action that was asserted. The test was not "mechanical or quantitative" or whether the defendant's activities with respect to the state were "a little more or a little less." ${ }^{226}$ Whether due process was satisfied was said to turn upon "the quality and nature of the activity in relation to the fair and orderly administration of the laws which it was the purpose of the due process clause to ensure." ${ }^{227}$ In light of the difficulty of interpretation and application that they have created, one wonders whether the Court's more recent efforts to particularize that test in terms of prongs, and multiple factors bearing on the satisfaction of those prongs, with predominant emphasis on the defendant's assumed purpose or intent, have constituted a significant improvement.

\section{Consistency with Existing Law}

The previous discussion suggests that the foundation requirement of personal jurisdiction in both interstate business and intentional tort cases is whether the defendant is or should be aware that the impact of his allegedly wrongful actions is substantially certain to be felt in the forum state. Of course, that does not mean that the defendant must be aware that the impact of his actions is in fact wrongful or tortious, or that the plaintiff must prove his case on the merits in order to establish jurisdiction in the forum. Rather, the touchstone should be whether the defendant is or should be aware that his conduct is substantially certain to have the kind of impact or create the risk of harm asserted by the plaintiff as the basis for its suit within the forum state. ${ }^{228}$ If

225. See supra Part II.

226. Int'l Shoe Co. v. Washington, 326 U.S. 310,319 (1945).

227. Id.

228. One possible objection to the suggested analysis is that it might allow a plaintiff to 
that threshold requirement is satisfied, the exercise of jurisdiction would be sustained unless an intervening cause is held to relieve the defendant of geographic responsibility for the consequences of his actions under a proximate cause-like analysis as previously discussed, ${ }^{229}$ or unless the exercise of jurisdiction is unreasonable after balancing the factors that the Supreme Court has identified as bearing on that inquiry. ${ }^{230}$ This approach appears quite consistent with the results courts in both the Burger King and Calder lines have reached.

In cases arising out of a defendant's conduct of interstate business activities, courts applying the Burger King test have assumed that a defendant who has chosen to conduct business in a particular forum reasonably may anticipate being sued there on tort, contract, and other claims arising out of those activities. ${ }^{231}$ The main difficulty presented by such cases has been in determining whether the defendant should be relieved of geographic responsibility for his business operations that have a foreseeable impact in the forum state where that impact was the result of the intervening act of a third party, such as a consumer, a wholesaler, or a manufacturer whose products incorporate a component part made by the defendant. These questions should be resolved by applying a proximate cause-like analysis to determine whether such intervening acts are sufficiently random, attenuated, and unpredictable to relieve the defendant of geographic responsibility for the foreseeable consequences of his acts in a particular state. $^{232}$

"bootstrap" his way to personal jurisdiction over a remote defendant by asserting a legally frivolous claim and obtaining a default judgment on that basis. The accepted principle that a default does not admit the legal sufficiency of the complaint, 10A CHARLES ALAN WRIGHT ET AL., FedERAL PRACTICE \& PROCEDURE § 2688 (3d ed. 1998), coupled with the principle that a default judgment is always open to collateral attack for lack of personal jurisdiction, id. $\S 2695$, make it clear that this strategy would not succeed. However, in order to promote the fundamental "notice" requirement of personal jurisdiction analysis, jurisdiction under the suggested approach should be sustained only where the legal theory asserted by the plaintiff as the basis for his action is clearly established as legally viable at the time the defendant's allegedly wrongful conduct took place.

229. See supra Part III.C.3.

230. See supra note 152 and accompanying text.

231. See, e.g., Cent. Freight Lines Inc. v. APA Transp. Corp., 322 F.3d 376, 386 (5th Cir. 2003) (applying Burger King to exercise personal jurisdiction over a contract claim and stating, in analyzing the reasonableness factors, that defendant had "fair waming that it could be sued in Texas for alleged breach of [contract] and for alleged intentional torts arising out of its performance under" the contract).

232. See supra Part III.C.3. A recent Third Circuit decision applying the Burger King test closely corresponds with our suggested approach. In Toys " $R$ " Us, Inc. v. Step Two, S.A., 318 F.3d 446 (3d Cir. 2003), the court rejected personal jurisdiction in New Jersey based on a Spanish company's allegedly infringing interactive Web site which permitted the purchase of merchandise "mimicking" that offered by the plaintiff. The court applied the Zippo test for personal jurisdiction in light of the Supreme Court's "purposeful availment" standard, concluding that the defendant's operation of an interactive Web site "alone" was insufficient absent additional evidence that the defendant had purposefully directed its activities at New Jersey customers. Although phrased in terms of "purpose," the key issue for the court was whether the plaintiff had shown that the defendant was aware that the Web site had resulted in sales to New Jersey residents. The court concluded that such knowledge was not established in view of the fact that the Web site was entirely in Spanish, merchandise could be shipped only to addresses in Spain, and the site was not designed to accommodate U.S. addresses. Id. at 454. 
Tort cases falling into the Calder line are not entirely consistent, but generally reflect a strong focus on defendant's awareness of the specific geographic fora in which his conduct may have the impact that provides the basis for the plaintiff's suit. Cases almost uniformly have rejected the idea that the foreseeable financial impact that a defendant's wrongful actions may have on a corporate plaintiff in its headquarters state is sufficient to sustain personal jurisdiction there. ${ }^{233}$ Such a rule would mean that a corporate plaintiff always could sue any defendant in the plaintiff's headquarters state no matter where the actual wrongful impact of the defendant's conduct occurred. ${ }^{234}$ Instead, courts applying Calder correctly have focused on the particular geographic location or locations where the defendant did anticipate or should reasonably have anticipated that its conduct would result in an invasion of the interest of the plaintiff that is the subject of the suit. In Far West Capital, Inc. v. Towne, ${ }^{235}$ for example, personal jurisdiction over Oregon and Nevada defendants in Utah was rejected in a case involving an alleged breach of contract and interference with contractual relations related to a project to supply power to a Nevada utility from Nevada geothermal resources. The plaintiff was a Utah resident, an initial solicitation had occurred there, and other Utah contacts, such as phone calls, faxes, an escrow account, and defendant's resident agent, existed. ${ }^{236}$ Nevertheless, the court, referring to both Burger King and Calder, focused on the fact that the most important negotiations took place in Nevada and the transaction was centered there. ${ }^{237}$ As a result, the focal point of the defendant's wrongful conduct and its wrongful impact were in Nevada, not Utah. ${ }^{238}$ In Chaiken $v$.

Two "random" sales solicited by representatives of the plaintiff in an apparent effort to manufacture jurisdiction were insufficient. The court concluded that defendant "scarcely recognized" that sales with U.S. residents had been consummated. Id. at 454-55.

233. See, e.g., IMO Indus., Inc. v. Kiekert AG, 155 F.3d 254, 263 (3d Cir. 1998) (explaining that "the mere allegation that the plaintiff feels the effect of the defendant's tortious conduct in the forum because the plaintiff is located there is insufficient to satisfy [the express aiming requirement of] Calder"); ESAB Group, Inc. v. Centricut, Inc., 126 F.3d 617, 625-26 (4th Cir. 1997) (refusing to exercise jurisdiction under Calder because even though the plaintiff's company was headquartered in the forum state, permitting Calder to be satisfied on this basis would mean that jurisdiction in intentional tort cases would always be appropriate in the plaintiff's home state, and would be based on a decision of the plaintiff, not the defendant); Far West Capital, Inc. v. Towne, 46 F.3d 1071, 1080 (10th Cir. 1995) (concluding that there was no personal jurisdiction under Calder since there was no evidence that defendants' alleged torts had any connection to Utah beyond the fact that it was plaintiff's corporate domicile); Southmark Corp. v. Life Investors, Inc., 851 F.2d 763, 773 (5th Cir. 1988) (noting that the fact that the plaintiff had its principal place of business in the forum was a "mere fortuity" and did not demonstrate that the defendant "expressly aimed its allegedly tortious activities" at the forum or that the forum "is even the focal point" of defendant's conduct).

234. ESAB Group, Inc., 126 F.3d at 625-27. The Ninth Circuit's decision in Dole Food Co. v. Watts, 303 F.3d 1104 (9th Cir. 2002), which sustained jurisdiction in California over a foreign defendant who allegedly had defamed the plaintiff by emphasizing that the plaintiff suffered sufficient economic harm resulting from defendants' conduct at its principal place of business, $i d$. at 1113-14, superficially appears inconsistent with this analysis, but, upon closer examination, is not. See infra note 250.

235. 46 F.3d 1071 (10th Cir. 1995).

236. Id. at $1073-74$.

237. Id. at 1080 .

238. Id.; accord Denver Truck \& Trailer Sales, Inc. v. Design \& Bldg. Servs., Inc., 653 N.W.2d 88, 92-93 (S.D. 2002) (rejecting jurisdiction in South Dakota because "[ $t$ ] he claim for 
VV Publishing Corp. ${ }^{239}$ the Second Circuit rejected jurisdiction in Massachusetts over a libel action against an Israeli newspaper with a small circulation in Massachusetts. The court emphasized that the newspaper had only a small circulation in Massachusetts, and that the allegedly defamatory article concerned the plaintiffs' activities in connection with a Jewish terrorist organization while they resided in Israel. ${ }^{240}$ The defendant failed Calder's express aiming requirement because its article was focused on Israeli events and the defendant believed that the plaintiffs had permanently settled in Israel. ${ }^{241}$ The Court concluded that the defendant had "reason to believe" that the effects of its article would be felt in Israel, not Massachusetts. ${ }^{242}$ In Revell v. Lidov, ${ }^{243}$ the Fifth Circuit rejected jurisdiction in a Texas action against Columbia University and one of its professors who had posted an allegedly defamatory article on the university's Web site. Applying the Zippo formulation, the court found that the Web site was "interactive," but held that jurisdiction was improper because the article did not refer to plaintiff's Texas activities and was not directed to Texas readers. ${ }^{244}$ The plaintiff's residence in the forum and his suffering of harm there, were insufficient to establish that Texas was the "focal point" of the article or the harm suffered. ${ }^{245}$ The court required the plaintiff to establish that the defendant's conduct had a "unique relationship" with the forum. ${ }^{246}$ The court noted that the article was directed at the "entire world" and did not specifically target Texas residents. ${ }^{247}$ In fact, the individual defendant's affidavit stated that he did not know the plaintiff was a forum resident. ${ }^{248}$ The court pointed out that " $[\mathrm{k}]$ nowledge of the particular forum in which a potential plaintiff will bear the brunt of the harm forms an essential part of the Calder test." ${ }^{249}$ Although the court's language regarding the focus of the defendant's conduct and the need for a unique relationship with the forum is arguably inconsistent with our approach, the court's result conforms with our analysis. Other cases generally consistent with the suggested approach are collected in the footnote. ${ }^{250}$

breach and negligence are directly related to the contract which was created, executed and performed in Colorado").

239. 119 F.3d 1018 (2d Cir. 1997).

240. Id. at $1027-29$.

241. Id. at $1028-29$.

242. Id. at 1029.

243. 317 F.3d 467 (5th Cir. 2002).

244. Id. at $472,475-76$.

245. Id. at 473 .

246. Id. at 474.

247. Id. at 475 .

248. Id.

249. Id.

250. In Noonan v. Winston Co., 135 F.3d 85 (1st Cir. 1998), the Court of Appeals for the First Circuit rejected jurisdiction over an action alleging claims for defamation, invasion of the right of privacy, and misappropriation and violation of the right of publicity based on the unauthorized use of a Massachusetts plaintiff's photograph in cigarette advertising in France. Even though some of the magazines containing the ad were distributed in Massachusetts, the defendants did not "direct" their activities toward Massachusetts. Id. at 91 . The advertisement contained French text and a French phone number, suggesting that the defendants created it for a French audience, and the defendants were unaware that magazines containing the ad would reach Massachusetts. Consistent with Justice Stevens's dicta in Asahi, the court indicated that the size of distribution of the offending material would help to determine whether the defendant 
had acted with sufficient "intent." Id. at 91 . The court's analysis centered around whether the defendant was or should have been aware that the allegedly wrongful impact of its conduct would be felt in Massachusetts. Similarly, in Schwarzenegger v. Fred Martin Motor Co., 374 F.3d 797 (9th Cir. 2004), the Court of Appeals for the Ninth Circuit held that an Ohio car dealership's alleged misappropriation of the plaintiff's likeness in an advertisement published only in Ohio did not satisfy Calder's "express aiming" requirement in the plaintiff's California action alleging that the unauthorized use of his image violated his right of publicity. The court found that the defendant's conduct was "expressly aimed" at Ohio, not California, even though it recognized that the plaintiff might suffer financial harm in California as a result of the defendant's conduct, and the defendant undoubtedly was or should have been aware that the plaintiff resided there. Id. at 807 . A better ground for rejecting jurisdiction would have been that the alleged wrongful impact of the defendant's conduct in diminishing the value of the plaintiff's reputation had occurred in Ohio, not California.

In ESAB Group, Inc. v. Centricut, Inc., 126 F.3d 617 (4th Cir. 1997), the Court of Appeals for the Fourth Circuit held that the defendants were not properly served under South Carolina's long-arm statute in an action by a South Carolina corporation alleging RICO and state tort violations arising from the alleged misappropriation of the plaintiff's trade secrets and customer lists in Florida. The only connection with South Carolina was the fact that the defendants knew that the Florida scheme, if successful, would result in lost sales by the plaintiff. However, the defendant had not "targeted" South Carolina, but had focused on customers throughout the United States and Canada. Id. at 625. The fact that the financial impact of the defendant's conduct was felt in South Carolina was "too unfocused to justify personal jurisdiction." Id. Although the court did not expressly state that personal jurisdiction should turn on whether the defendant was or should be aware that the wrongful impact (as opposed to the financial consequences) of its actions would be felt in a particular state, its analysis in fact focused on the location of the plaintiff's customers and, consequently, the geographic locus of the wrongful impact of the defendant's conduct.

By contrast, in Panavision International, L.P. v. Toeppen, 141 F.3d 1316 (9th Cir. 1998), the Court of Appeals for the Ninth Circuit sustained jurisdiction in California over a cyberspace "pirate" case in which the defendant, a resident of Illinois, had registered the plaintiff's trade name on the Internet. Although the court relied upon the fact that the defendant, in response to the plaintiff's cease-and-desist letter, attempted to "extort" money from the plaintiff through settlement, it also placed heavy emphasis on the fact that the defendant was aware that the wrongful impact of his conduct would be felt by the plaintiff in California where its principal place of business was located and where the heart of the motion picture and television industries was located. Id. at 1322.

In IMO Industries, Inc. v. Kiekert AG, 155 F.3d 254 (3d Cir. 1998), the court rejected personal jurisdiction in New Jersey over a German corporation that the plaintiff New Jersey corporation alleged had tortiously interfered with the sale of the plaintiff's Italian subsidiary to a competing French corporation. Applying the effects test of Calder, the court stated that most courts applying Calder to business torts had adopted a "narrow construction." Id. at 261. The court interpreted previous decisions applying Calder as holding that the "brunt of the harm" requirement is not satisfied when the tortious injury is to contracts or property not located in the forum. See id. at 265-66. Again, the court's approach was focused on the defendant's awareness of the geographic locus of the impact of its conduct on the interest that the law sought to protect. By contrast, in Harris Rutsky \& Co. Insurance Services, Inc. v. Bell \& Clements Ltd., 328 F.3d 1122 (9th Cir. 2003), the Court of Appeals for the Ninth Circuit applied Calder to sustain jurisdiction in California over tortious interference claims where the contractual relationship that a London defendant allegedly had interfered with by its conduct in London was centered in California. Similarly, in Wien Air Alaska, Inc. v. Brandt, 195 F.3d 208 (5th Cir. 1999), the Court of Appeals for the Fifth Circuit sustained personal jurisdiction in Texas over a German attorney for a Texas airline company that had sued him for fraud, breach of contract, and breach 


\section{Implications of the Suggested Analysis}

\section{a. Jurisdiction does not turn on the primary incidence of the harm}

If, as we argue, the defendant's awareness of the geographic locus of the alleged wrongful impact of his conduct should provide the focal point of personal jurisdiction analysis, the following question remains: "how much harm, or what proportion of the overall harm," must be suffered in the forum? ${ }^{251}$ In Dole Food Co. v. Watts, ${ }^{252}$ the Court of Appeals for the Ninth Circuit suggested that language in some cases to the effect that the "brunt of the harm" must be suffered in the forum was inconsistent with the Supreme Court's decision in Keeton v. Hustler Magazine, Inc., ${ }^{253}$ but found it unnecessary to resolve the issue because jurisdiction was proper in either event. Some recent cases have implied that the defendant's awareness that his conduct might injure the plaintiff in the forum is not sufficient to satisfy Calder's targeting requirement if the primary focus and impact of the defendant's conduct lies elsewhere. In Young $v$. New Haven Advocate, ${ }^{254}$ for example, the Court of Appeals for the Fourth Circuit rejected jurisdiction in Virginia in an action by the warden of a Virginia prison who alleged that he had been defamed in an article posted on the Internet by Connecticut newspapers. The court held that the defendants had not posted the articles with the "manifest intent" of targeting the plaintiff or a Virginia audience. ${ }^{255}$ The newspapers had minimal or no circulation in Virginia and did not solicit subscribers in Virginia. ${ }^{256}$ None of the reporters traveled to Virginia to write the articles, although they did place some telephone calls to Virginia. ${ }^{257}$ Applying its previous decision in ALS Scan, ${ }^{258}$ the

of fiduciary duty in the course of the attorney's representation of the plaintiff. Even though the business transaction at issue was, as in $I M O$, centered in Europe, the court sustained jurisdiction under Calder because the tortious consequences of the defendant's conduct were felt in Texas. In particular, the defendant had directed letters, faxes, and phone calls toward the forum which contained the fraudulent misrepresentations that were at the heart of the lawsuit, and the plaintiff detrimentally relied on those misrepresentations there. Id. at 212. Likewise, in Dole Food Co. $v$. Watts, 303 F.3d 1104 (9th Cir. 2002), the Court of Appeals for the Ninth Circuit sustained jurisdiction in California in an action by a corporation having its principal place of business in California alleging that officers of a foreign division had fraudulently induced it to enter a disadvantageous transaction. Although much of the court's analysis erroneously focused on the "metaphysical question of where a corporation suffers economic harm," id. at 1113, the court also based its decision on the fact that, as a result of the fraud, "Dole managers in California were induced to approve the injurious transactions." Id. at 1114. Compare Helmer v. Doletskaya, 393 F.3d 201 (D.C. Cir. 2004) (rejecting jurisdiction in the District of Columbia over claims for breach of a contract entered in the District where the performance of the contract and impact of the breach occurred in Russia, but sustaining jurisdiction over a contract claim based on failure to repay credit card charges where those charges were billed to an address in the District and payment arrangements were made there).

251. Dole Food Co. v. Watts, 303 F.3d 1104, 1112 (9th Cir. 2002).

252. Id. at $1112-13$.

253. 465 U.S. $770,780(1984)$.

254. 315 F.3d 256 (4th Cir. 2002).

255. Id. at 264 .

256. Id. at $259-60$.

257. Id. at 260 . 
court rejected the warden's argument that personal jurisdiction was proper in Virginia because the defendants knew that the plaintiff was a Virginia resident and his reputation was harmed there where he lived and worked. ${ }^{259}$ The court held that the plaintiff must show that the defendants intended to target a Virginia audience-a requirement that was not satisfied because the content of the Web site was "local," serving readers in Connecticut by commenting on Connecticut's prison transfer policy. ${ }^{260}$ This approach should be rejected, to the extent that it suggests that some sort of intent, targeting, or aiming at the forum beyond the defendant's actual or constructive awareness that the allegedly tortious impact of its conduct is substantially certain to be felt there is required, or that the primary impact of the defendant's conduct must lie in the forum. By contrast, the Court of Appeals for the Fourth Circuit's decision in Carefirst of Maryland, Inc. v. Carefirst Pregnancy Centers, Inc. ${ }^{261}$ rejecting jurisdiction in a Maryland trademark infringement action based on the defendant's operation of an allegedly infringing semi-interactive Web site having a strongly local Chicago area character was correct. That was not because a strongly local Web site focused on an audience in another state cannot support jurisdiction in a state where its injurious effects are felt, as the court assumed. ${ }^{262}$ Rather, it was because, on the particular facts of the case, the defendant had no reason to believe that any confusion, dilution, or other adverse effects that trademark law is intended to address had occurred in Maryland. ${ }^{263}$

\section{b. Jurisdictional analysis should be claim-specific}

An approach focused on the particular forum in which the defendant is or should be aware that his conduct will invade the protected interest at stake means that jurisdictional analysis should be claim-specific. That is because the geographic locus of the harm that the law seeks to prevent may vary depending on the type of claim for relief that the plaintiff asserts. In Schwarzenegger v. Fred Martin Motor Co., ${ }^{264}$ the Court of Appeals for the Ninth Circuit noted that in applying the Calder effects test, "[the] 'express aiming' analysis depends, to a significant degree, on the specific type of tort . . . at issue." ${ }^{265}$ In Remick v. Manfredy, ${ }^{266}$ the Court of Appeals for the Third

258. ALS Scan, Inc. v. Digital Serv. Consultants, Inc., 293 F.3d 707, 714 (4th Cir. 2002). The $A L S$ test allows a state to "exercise judicial power over a person outside of the State when that person (1) directs electronic activity into the State, (2) with the manifested intent of engaging in business or other interactions within the State, and (3) that activity creates, in a person within the State, a potential cause of action cognizable in the State's courts." Id. (emphasis added).

259. Young, 315 F.3d at 264.

260. Id. at 263.

261. 334 F.3d 390 (4th Cir. 2003).

262. Id. at $400-01$.

263. The only donation received by the defendant from a Maryland resident during the relevant time period was from the plaintiff's attorney attempting to bolster its case. Id. Compare Rio Properties, Inc. v. Rio International Interlink, 284 F.3d 1007 (9th Cir. 2002), where jurisdiction in Nevada in a trademark infringement action against a Costa Rican entity was sustained because the defendant, in addition to its operation of a passive Web site, had targeted the plaintiff's Nevada customers in an advertisement published in Nevada.

264. 374 F.3d 797 (9th Cir. 2004).

265. Id. at 807; see also Helmer v. Doletskaya, 393 F.3d 201 (D.C. Cir. 2004). 
Circuit adopted such a claim-specific approach, sustaining jurisdiction over some claims where the geographic incidence of the defendant's wrongful conduct would be felt in the forum, while rejecting jurisdiction over others. The plaintiff was a Pennsylvania attorney who had been hired by Manfredy and lawyers located in Indiana and Illinois to negotiate fight contracts for Manfredy. ${ }^{267}$ Manfredy later discharged the plaintiff for failing to adequately represent his interests. ${ }^{268}$ The complaint alleged claims for breach of contract, defamation, misappropriation of image and likeness, and tortious interference arising from the termination of employment, the defendants' sending of allegedly defamatory letters to the plaintiff in Pennsylvania, and the posting of the plaintiff's image on a Web site. ${ }^{269}$ The court sustained jurisdiction as to the breach of contract claim under a totality of the circumstances test apparently derived from Burger King. ${ }^{270}$ It noted that the defendant had solicited the contractual relationship with the plaintiff in Pennsylvania where the services were performed, had made at least one payment there, and had sent the termination letter there. ${ }^{271}$. For the same reasons, jurisdiction over the tortious interference claim was proper in Pennsylvania because the contractual services interfered with were centered there. ${ }^{272}$ By contrast, the court rejected jurisdiction over the claims for defamation and misappropriation of image and likeness, applying Calder's targeting approach. ${ }^{273}$ The court noted that the letters were published throughout the boxing community and were not expressly focused on Pennsylvania. ${ }^{274}$ In fact, there was no indication that the letter was targeted at anyone in Pennsylvania other than the plaintiff. ${ }^{275}$ Similarly, the Web site on which the plaintiff's image was posted was accessible worldwide. ${ }^{276}$

For the reasons previously discussed, the court's implication in connection with the defamation and misappropriation claims that jurisdiction should be rejected even if the defendant was aware that the wrongful impact of his conduct would be felt in Pennsylvania, on the ground that the defendant's conduct was not uniquely focused on Pennsylvania or that the primary impact of the defendant's conduct was felt elsewhere, should be rejected. However, the court's claim-specific approach, which simultaneously upheld jurisdiction over the contract-related claims on the apparent ground that the types of injuries that the law of contracts and tortious interference seek to prevent took place there, was correct. If personal jurisdiction was lacking over the remaining tort claims, it should have been because the defendant neither was nor should have been aware that the allegedly tortious impact of its conduct would be felt in Pennsylvania, not because it was also (or more strongly) felt elsewhere. ${ }^{277}$

266. 238 F.3d 248 (3d Cir. 2001).

267. Id. at 252-53.

268. Id. at 253.

269. Id. at 256,260. Remick's claims against Manfredy included "breach of contract and the tort claims of defamation, civil conspiracy, and misappropriation of image and likeness." Id. at 256. The claims against the law firm included defamation, conspiracy, and tortious interference with contract. Id. at $257,263$.

270. Id. at $256-57$.

271. Id. at 256.

272. Id. at 260 .

273. Id. at 257-59.

274. Id. at 259.

275. Id.

276. Id.

277. Cf. Gordy v. Daily News, 95 F.3d 829, 833-34 (9th Cir. 1996) (upholding jurisdiction 


\section{c. Jurisdictional analysis should turn on the nature of the legally protected interest at stake}

An approach to issues of personal jurisdiction focused on the defendant's actual or constructive knowledge of the geographic incidence of the harm or risk of harm that his conduct has caused to the interest asserted by the plaintiff requires careful attention to the nature of the interests that particular bodies of law seek to protect. In cases involving informational wrongs and intangible interests, identifying the geographic locus of the legal invasion at issue, and the defendant's actual or constructive awareness of that locus, may present considerable difficulty. As discussed further below, this may be particularly true in cases involving informational wrongs committed through the omnipresent instrumentality of the Internet. However, that difficulty does not support rejecting our suggested approach. The necessity to mark out sometimeselusive geographic boundaries and limits is inherent in the territorial approach to issues of personal jurisdiction and state sovereignty that the Supreme Court has consistently followed since Pennoyer $v$. Neff. ${ }^{278}$ The Court's later expansion of the strict presence of persons or property within the forum state approach taken by Pennoyer continued to require that a defendant's conduct establish a sufficient territorial connection with the forum state to respect limits on state sovereignty and make the exercise of personal jurisdiction over the defendant fundamentally fair. ${ }^{279}$ No matter what test of personal jurisdiction is adopted, the same problems of ascribing territorial location to informational and intangible harms will remain.

Moreover, the difficulty of identifying the geographic locus of the harm to the plaintiff's protected interests is easily overstated, even where informational harms and intangible interests are at stake. The law of defamation seeks to protect the plaintiff's reputational interest, and the states in which the plaintiff possesses a reputation that might be injured are identifiable, as are the states where the defendant's allegedly defamatory publications are circulated and read. ${ }^{280}$ Patent law seeks to protect the plaintiff's right to exclusive use and enjoyment of the patented process or invention. ${ }^{281}$ The state or states in which an alleged infringer has invaded those rights can be identified, as can the geographic locus of copyright infringement. ${ }^{282}$ Trademark and

over a California defamation action brought by a Califormia resident even though ninety-nine percent of the defendant's circulation was in New York and less than twenty copies of the offending newspaper had been distributed in California).

278. 95 U.S. 714 (1877).

279. See supra Part I.A.

280. Victor E. Schwartz, Kathryn Kelly \& David F. Parlett, Prosser, Wade \& SCHWARTZ'S TORTS 932 (10th ed. 2000) (noting that a plaintiff alleging defamation can only obtain damages to the extent that he can prove "impairment of reputation and standing in the community").

281. Robert P. Merges, Peter S. Menell \& Mark A. Lemley, INTEllectual Property in THE NEW TECHNOLOGICAL AGE 22 (3d ed. 2003).

282. Patents include a "[p]rocess, machine, manufacture, or composition of matter." Id. at 21. Infringing processes, manufactures, etc., have a geographically identifiable location. Similarly, in order for a work to be copyrightable, it must be "fixed in a "tangible medium of expression." Id. at 336 (citing H.R. REP. No. 94-1476, at 52-53 (1976)). Since every copyright work is "fixed in a tangible medium," in order to infringe a copyright, the work must be reproduced or displayed in an identifiable state. 
trade dress law protects nonfunctional names and dress that serve to identify and distinguish goods and prevent customer confusion. Trademarks are infringed or diluted when customer confusion is created or when the connection in customers' minds of a mark with one source is destroyed. ${ }^{283}$ To establish a trademark infringement or dilution claim, a plaintiff must demonstrate that his trademark was used in connection with products sold in the market. ${ }^{284}$ In such cases, the critical issue under the suggested analysis would be whether the defendant was or should have been aware that the plaintiff's mark was being used in the forum state and whether the defendant's mark was exposed to or accessed by the plaintiff's customers there. ${ }^{285}$ The law of unfair competition seeks to protect the plaintiff's interest in the sale of its products or services in a competitive market that has not been distorted by the defendant's misleading or wrongful conduct. ${ }^{286}$ Again, the geographic area or areas in which such unfair competition has allegedly taken place can be determined.

The geographic locus of the invasion of other intangible interests may be more difficult to ascertain. For example, the law of trade secrets seeks to protect the commercial advantage that the developer of trade secret information derives. Such an interest may be invaded where one who has misappropriated the secret has used it to commercial advantage. But a trade secret may equally be misappropriated by one who seeks no commercial advantage, but simply seeks to destroy its value to the rightful owner for ideological or noncommercial reasons. ${ }^{287}$ In such cases, the defendant has taken the plaintiff's property, but unlike cases involving tangible real or personal property, the geographic location of the taking is not self-evident. In such cases, courts applying the suggested approach might adopt common law rules corresponding with the society's normal expectations that would ascribe a geographic location to trade secret information at the plaintiff's headquarters or principal place of business, or, where written or other tangible embodiments of the protected information have been taken, at the place where that taking occurred. ${ }^{288}$

283. Id. at $625-26$.

284. See id. at 572 .

285. Thus, the intent or awareness element of personal jurisdiction analysis would be more demanding than that applicable to the determination of liability. Currently, under federal law, the Lanham Act dealing with trademark infringement does not require a defendant to have any knowledge or intent to infringe upon another's trademark. Stein, Regulatory Precision, supra note 9, at 444 ("[D]efendant may be liable for trademark infringement under $\S 43$ (a) even if he or she innocently used an infringing mark and lacked any intent to confuse consumers as to the source of the goods." (quoting Island Insteel Sys., Inc. v. Waters, 296 F.3d 200, 213 (3d Cir. 2002))); see also 15 U.S.C. § 1125 (2000).

286. See, e.g., CAL. BUS. \& PROF. CODE $§ 17200$ (West 1997) (defining "unfair competition" to include "unlawful, unfair or fraudulent business ... practice and unfair, deceptive, untrue or misleading advertising").

287. See Pavlovich v. Superior Court, 58 P.3d 2 (Cal. 2002).

288. An example of an approach that provides a geographic location for jurisdiction over Internet activities is the Anticybersquatting Consumer Protection Act (ACPA), 15 U.S.C. $\S$ 1125(d) (2000). The ACPA contains in rem jurisdiction provisions that determine that the registration of a domain name in a jurisdiction constitutes "presence" and allows that forum jurisdiction over it. See, e.g., Caesars World, Inc. v. Caesars-Palace.com, 112 F. Supp. 2d 502 (E.D. Va. 2000) (upholding the ACPA). See also Andrew J. Grotto, Due Process and In Rem Jurisdiction Under the Anti-Cybersquatting Consumer Protection Act, 2 COLUM. SCI. \& TECH. 
d. Jurisdictional analysis does not turn solely on defendant's in-forum activities

The suggested analysis would also help to resolve an ongoing conflict among the circuits regarding the required relationship between the defendant's direct contacts with the forum state and the plaintiff's cause of action. Some circuits applying the purposeful availment test have concluded that the defendant's in-state contacts must be the proximate cause of the plaintiff's injuries. ${ }^{289}$ Others have held it sufficient that the defendant's forum-related contacts are the but-for cause of the plaintiff's injuries. ${ }^{290}$ Still others appear to have adopted an intermediate position. ${ }^{291}$ The Supreme Court has yet to resolve the required relationship between the defendant's forum-related contacts and the plaintiff's cause of action to sustain the exercise of personal jurisdiction. ${ }^{292}$

The Third Circuit recently addressed these conflicting currents in Miller Yacht Sales, Inc. v. Smith. ${ }^{293}$ The plaintiff, a New Jersey corporation, had negotiated with defendants to allow them to become exclusive dealers for certain of Miller Yacht's boats. During the negotiations, defendants visited New Jersey where they obtained a copy of a Miller Yacht sales brochure containing photographs and floor plans for its yachts. They also arranged to go to China at Miller Yacht's expense to observe the manufacture of the yachts and meet Miller's business contacts there. Later, when negotiations fell through, defendants were alleged to have directed advertisements and sales solicitations incorporating Miller Yacht's intellectual property into New Jersey in an effort to sell yachts, as well as to have intentionally interfered with Miller's business relationships in China. Miller Yacht sued for trade-dress infringement, unfair competition, and intentional interference with prospective economic advantage. Applying "traditional personal jurisdiction analysis" 294 under the Burger King/Volkswagen test, the majority upheld jurisdiction in New Jersey over all of the claims. In so doing, it declined to follow those courts requiring that the defendant's contacts with the forum be the proximate cause of the plaintiff's injury. Although declining to decide precisely what type of relationship short of that standard would support the exercise of personal jurisdiction in the abstract, the majority found it sufficient that defendants had communicated with New Jersey to set up their trip to China and later had misappropriated the photographs and floor plans that they obtained in New Jersey in an attempt to sell boats in New Jersey. ${ }^{295}$ By contrast, the dissenting judge argued that a strict proximate cause relationship was required to establish the necessary jurisdictional connection between the defendants' forum-related contacts and the plaintiffs' claims. Applying that test, jurisdiction over the tortious interference

L. REv. 1, 5 (2001), http://www.stlr.org/html/volume2/grotto.pdf (expressing support for a "relaxed minimum contacts standard for in rem jurisdiction as it applies narrowly to the ACPA, primarily on the basis of a pair of procedural safeguards contained in the in rem provisions").

289. See, e.g., Mass. Sch. of Law, Inc. v. Am. Bar Ass'n, 142 F.3d 26, 35 (1st Cir. 1998).

290. See, e.g., Doe v. Am. Nat'l Red Cross, 112 F.3d 1048, 1051 n.7 (9th Cir. 1997).

291. See, e.g., Miller Yacht Sales, Inc. v. Smith, 384 F.3d 93, 99-100 (3d Cir. 2004); see also id. at 103-04 (Scirica, J., concurring and dissenting) (reviewing conflicting authorities).

292. See, e.g., Camival Cruise Lines, Inc. v. Shute, 499 U.S. 585, 589 (1991); Helicopteros Nacionales de Columbia, S.A. v. Hall, 466 U.S. 408, 415 n.10 (1984).

293. 384 F.3d 93 (3d Cir. 2004).

294. Id. at $96 \mathrm{n} .2$.

295. Id. at $97,99-101$. 
claim was improper because the proximate cause of any interference with plaintiffs' economic advantage was defendants' conduct in China or their principal place of business, not their contacts with New Jersey. ${ }^{296}$

Both the majority and the dissent regarded the Calder effects test as a distinct test for personal jurisdiction, requiring a different jurisdictional analysis. However, the majority found it unnecessary to apply the effects test because of its conclusion that jurisdiction was proper under "more traditional" purposeful direction analysis rather than the "more demanding relatedness requirement of the effects test."297 By contrast, the dissent would have remanded for separate application of the effects test to the interference with economic advantage claim. ${ }^{298}$

The difficulty of determining the required degree of relationship between a defendant's forum contacts and the plaintiff's cause of action, as well as the necessity of applying separate jurisdictional tests to reach potentially inconsistent results, would be avoided by the approach suggested here. Rather than first examining the defendant's in-forum activities to determine whether they bore a sufficient proximate cause or other relationship to the plaintiffs' cause of action, and then separately applying the effects and targeting analysis of Calder, our approach would apply a unified test under which the totality of the defendant's activities would be examined to determine whether, as a result, the defendant should have foreseen that they were substantially certain to give rise to the impact asserted by the plaintiff as the basis for its claims in the forum state. Under this analysis, the difficulties posed by the relatedness inquiry, insofar as it focuses solely on defendants' forum-related contacts, disappear. ${ }^{299}$

\section{Application to Internet Activities}

For the reasons already discussed, a unique test of personal jurisdiction should not be adopted for cases involving wrongs committed by means of the Internet. At the same time, traditional tests, when interpreted in light of a defendant's ambiguously defined purpose or intent, also are inadequate-both because of their uncertain meaning in this new context, and because it is unclear which of the various tests should be applied.

Cases fashioning new tests for personal jurisdiction in Internet cases, or straining at the meaning of old ones, clearly are correct in one respect. Issues of personal

296. Id. at 107.

297. Id. at 97,99 ; see also id. at 96 n.2.

298. Id. at 108 (Scirica, C.J., dissenting).

299. Under our suggested standard, the jurisdictional inquiry in Miller Yacht would be easily resolved in favor of sustaining personal jurisdiction on all of the plaintiffs' claims. The required degree of "relatedness" to the defendant's in-forum contacts also troubled the California Supreme Court in Snowney v. Harrah's Entm't, Inc., 112 P.3d 28 (Cal. 2005). In holding that Nevada hotels were subject to jurisdiction in California in an action for fraud and related claims based on their failure to provide notice of an energy surcharge at the time of reservation, the court rejected a "proximate cause" or "substantive relevance" test in favor of a broader "substantial connection" test applied in previous decisions. Id. at 44. However, the outcome of the case was consistent with the test suggested here because the court relied centrally on the fact that the impact of the defendant's misrepresentations was felt by California residents in Califomia. Id. 
jurisdiction are uniquely difficult in such a setting because of the special characteristics of the Internet itself. Most notably, information posted on the Internet is accessible by anyone, anywhere, and at any time, and such access takes place by virtue of the intervening acts of computer users, rather than those of the information posting party alone. One approach to this unique attribute would be to conclude that, having deliberately chosen to use a medium that may lead his wrongful conduct to cause harm anywhere, the Internet poster should be held to be on notice that he may be sued for such harm in any jurisdiction where access and consequent harm results. ${ }^{300}$ Perhaps the single most outstanding characteristic of cases considering issues of personal jurisdiction in this setting is their rejection of such an approach. ${ }^{301}$ Even though a defendant might be said to be on notice of the possibility of suit anywhere in such cases, the courts instead have required that the defendant in Internet cases have established some unique connection with the particular forum state before being subjected to. suit there. ${ }^{302}$ Such a requirement for geographic particularity seems implicit in both the Burger King and Calder line of cases. On policy grounds, one might note the extreme deterrent to socially desirable Internet activity that would be presented by an approach subjecting any Internet poster to suit anywhere that some person might claim that its legally protected interests have been invaded. ${ }^{303}$ Expanding the geographic responsibility of an Internet poster for the effects of its actions to such a degree would make the notice component of the Supreme Court's personal jurisdiction jurisprudence vacuous, would raise prospects of severe unfairness to defendants, and would sweep beyond what is necessary to protect the legitimate sovereign interests of the states.

A cautionary note is in order, however. The difficulty in Internet cases is not that access to the wrongful posting occurs by means of the unilateral act of a third party. It is true that the intervening act of another is involved, but the likelihood of such an act is the intended (in the sense that it is substantially certain to result), natural, and entirely foreseeable result of the posting itself. A proximate cause-based analysis would not relieve the defendant of geographic responsibility for the effects of his posting merely because the harm did not occur until a third party had accessed the information in question, any more than the manufacturer of a product would be relieved of geographic responsibility for injuries to consumers of its product simply because those injuries would not have occurred unless the injured consumers unilaterally had decided to accept the manufacturer's offer of purchase and use.

300. See Leif Swedlow, Three Paradigms of Presence: $A$ Solution for Personal Jurisdiction on the Internet, 22 OKLA. CITY U. L. REV. 337, 370 (1997) (describing this as the "spider web" approach to personal jurisdiction on the Internet); Richard Philip Rollo, The Morass of Internet Personal Jurisdiction: It is Time for a Paradigm Shift, 51 FLA. L. REV. 667, 679 (1999).

301. See, e.g., GTE New Media Servs., Inc. v. BellSouth Corp., 199 F.3d 1343, 1350 (D.C. Cir. 2000); Cybersell, Inc. v. Cybersell, Inc., 130 F.3d 414, 420 (9th Cir. 1997); Zippo Mfg. Co. v. Zippo Dot Com, Inc., 952 F. Supp. 1119, 1124 (W.D. Pa. 1997); Bensusan Rest. Corp. v. King, 937 F. Supp. 295, 301 (S.D.N.Y. 1996); Pavlovich v. Superior Court, 58 P.3d 2, 10 (Cal. 2002). But see Maritz, Inc. v. Cybergold, Inc., 947 F. Supp. 1328 (E.D. Mo. 1996); Inset Sys., Inc. v. Instruction Set, Inc., 937 F. Supp. 161 (D. Conn. 1996).

302. See supra note 301.

303. See Stein, Regulatory Precision, supra note 9, at 453. 
Nor is the central difficulty in Internet cases created by the fact that a defendant has undertaken conduct that might subject itself to jurisdiction everywhere, rather than only in one or a few states. A tortfeasor who mails a thousand bombs to recipients in one state, and one to recipients in each of the other forty-nine states, should not be relieved from geographic responsibility for the consequences of his actions in each of those states simply because he is subject to suit everywhere, or because his conduct has a uniquely intensive relationship with a single state. The problem in Internet cases is not that the defendant is potentially subject to suit everywhere, but that he is potentially subject to suit anywhere, without having any particular reason to know where that might be. This lack of predictability and geographically specific notice lies at the heart of the difficulties that the courts have experienced in applying traditional jurisdictional concepts in cases in which the instrument of wrongdoing is an Internet posting. The case of the Internet posting is more analogous to one in which a defendant throws a bottle containing poisonous gas into the ocean, with awareness that it may cause injury to someone, somewhere, if it is found and opened someday.

This difficulty remains even if the issue is, as we suggest that it should be, whether the defendant should be aware the harm or risk of harm caused by his conduct is substantially certain to result in the forum state, rather than whether he is in fact aware that it will. No easy means typically exist to determine the precise geographic jurisdiction in which Internet postings are accessed by remote users unless the sites themselves request and obtain that information. This fact no doubt underlies the conclusion of Zippo and cases adopting its reasoning that posting information on a passive Web site is not sufficient to subject the poster to jurisdiction in a remote state where it may be accessed. The Zippo formulation is inadequate in this regard, however, because in some cases involving purely passive Web sites, the very nature of the posting, or additional facts of which the defendant is or should be aware will provide the defendant with the required geographically specific notice that its conduct will have its claimed wrongful impact in a particular forum state.

Suppose the defamatory article in Calder, for example, had been posted only on a passive Web site, rather than published in California through circulation of the National Enquirer there. If defendants were (or should have been) aware that their Web site was being accessed by California readers, the result should have been the same. The critical difficulty in such cases lies in determining whether the defendants were on notice that their posting would be or had been accessed in the forum. Where only passive Internet activity is involved, actual or constructive awareness will not exist unless the defendant is placed on notice of such access by other means, such as a cease-and-desist letter, ${ }^{304}$ independent reports, or other facts. This helps to explain why Zippo recognized an intermediate category of cases for information posted on interactive Web sites. Where such interaction is possible, information gained by the poster by means of that interaction may establish that it is or should be aware that the wrongful effects of its conduct are being felt in the forum state. Where there are no additional facts providing such notice, then perhaps Zippo can be argued to be correct. But where they do exist, Zippo surely is wrong, regardless of the passive nature of the defendant's Web site.

304. This is not to say that a cease-and-desist letter alone should subject a defendant to personal jurisdiction in the home state of the sender. See Part III.C.7. 
But what if the publication in Calder had been only by means of a passive Web site, and there were no additional facts placing the defendant on notice that the site would be accessed by California readers so as to damage the plaintiff's reputation there? Would subjecting the defendant to personal jurisdiction in California cross the forbidden line by subjecting the defendant to suit anywhere for the effects of its Internet postings? This is a difficult question that might reasonably be resolved either way. It is true that no easy means exist for a defendant in such a case to determine whether its posting has been accessed, or with what frequency, in a particular state. But the number of hits experienced by a Web site might be determined with some effort, and this perhaps should be required in circumstances such as Calder, where the posting is part of an ongoing commercial activity rather than an isolated noncommercial event and where the defamatory character of the posting is apparent. If a defamatory Web site resembling the magazine article in Calder were experiencing a substantial number of hits, it would perhaps not be unreasonable to require the defendant to assume that they are geographically dispersed, and that they will cause injury to the plaintiff in her home state, where she resides and where her activities and reputation are centered, thus placing a duty of reasonable inquiry upon the defendant in such circumstances. Just as due process requires a plaintiff, under Mullane v. Central Hanover Bank, ${ }^{305}$ to make a reasonable ex post effort to notify the defendant of the action when it is commenced, due process might be held to require, in limited circumstances, an ex ante duty of reasonable inquiry on a prospective defendant to determine the geographic scope of the impact of its activities. The scope of that duty would vary depending on such factors as the allegedly tortious character of the posting, ${ }^{306}$ the volume, continuity and duration of the activities in question, their commercial or noncommercial nature, and the evolution and availability of technology providing a cost-effective means of obtaining the relevant information. ${ }^{307}$ Of course, where information is gained on an interactive Web site that places the defendant on notice that access and injury is occurring in the forum state, or where the defendant is conducting business over the Web site with residents of California or some other particular state, the result would follow as a matter of course. But the ultimate question in such cases is not whether the case falls into one of Zippo's three categories, but whether, under all of the circumstances, the defendant is or should be aware that the claimed wrongful impact of its Internet posting is substantially certain to be felt in the forum state. ${ }^{308}$

305. 339 U.S. $306(1950)$.

306. Thus, a duty of inquiry might be imposed where intentionally tortious wrongs are involved, but not where claims of negligence or strict liability are at issue.

307. See Stein, Regulatory Precision, supra note 9, at 452 (stating that "new technologies are emerging that will pinpoint the geographic location of [I]nternet users").

308. This approach would help to explain, for example, the divergent results in the Cybersell and Bancroft \& Masters cases previously discussed. See supra note 83. In the former case, the record contained no indication that anyone other than the plaintiff had ever accessed Florida Cybersell's Web site in Arizona, making any claim that the alleged trademark infringement by the Florida defendant's Web site had its geographic impact there implausible. By contrast, in Bancroft \& Masters, the Georgia defendant had deliberately attempted to divest a California company of its valuable domain name, a deprivation of property whose effects the defendant should have ascribed to the plaintiff's home state. Similarly, in Bensusan Restaurant Corp. $v$. King, 126 F.3d 25, 29 (2d Cir. 1997), the Second Circuit held that New York's long arm statute 


\section{Litigation Threats and Declaratory Judgment Actions}

An approach to issues of personal jurisdiction focused on a defendant's actual or constructive knowledge of the geographic scope of the effects of his allegedly wrongful activities also would assist in determining the jurisdictional significance that should be ascribed to cease-and-desist letters and other litigation threats and in identifying the fora in which actions seeking declaratory judgments of legality may be maintained.

Cease-and-desist letters may play more than one jurisdictional role. When sent by a plaintiff to an alleged infringer or wrongdoer in another state, they serve to place the recipient on notice that it allegedly is causing injury to a plaintiff headquartered in a particular location. This fact in itself, however, should not be sufficient to subject the defendant to personal jurisdiction in the home state of the sender. As previously discussed, a corporation may suffer financial harm at its headquarters that is the result of the wrongful impact of the defendant's activities elsewhere. ${ }^{309}$ For example, in Cybersell, Inc. v. Cybersell, Inc. ${ }^{310}$ Cybersell Arizona sent an e-mail to Cybersell Florida claiming that Cybersell Florida's passive Web site infringed its service mark. ${ }^{311}$ This may have placed Cybersell Florida on notice that the plaintiff was headquartered in Arizona, but did nothing to suggest that the Web site had any direct impact in Arizona. In fact, the record contained no indication that anyone other than the plaintiff had ever accessed the defendant's Web site in Arizona.

Beyond placing (or failing to place) the defendant on notice of the geographic scope of the impact of his allegedly wrongful activities, a cease-and-desist letter or other litigation threat itself may create the wrongful impact that the suit seeks to remedy or prevent. Thus, in Bancroft \& Masters, Inc. v. Augusta National, Inc., ${ }^{312}$ the Georgia defendant sent a letter, challenging the plaintiffCalifornia computer service company's use of a domain name, to NSI, the Virginia company that had registered the allegedly infringing name. The Court of Appeals for the Ninth Circuit sustained jurisdiction over the Georgia defendant in the plaintiff's California action seeking a declaratory judgment of noninfringement. ${ }^{313}$ That holding was correct because the defendant was or should have been on notice that the allegedly wrongful impact of its activities in threatening the plaintiff's continued use of its domain name would be felt by the plaintiff in California where it carried on its business operations. The fact that the letter was sent to Virginia rather than California was irrelevant. It was the geographic locus of the impact of the letter that mattered, not the address of its recipient. ${ }^{314}$

was not satisfied in an action by the owner of New York's famous Blue Note jazz club against a Missouri cabaret of the same name alleging unfair competition and trademark dilution by means of the cabaret's Web site. The result under the due process clause should have been the same. There was no indication that any New York consumer had accessed the site, and any confusion or dilution of plaintiff's mark in the eyes of Missouri customers of the cabaret would have occurred in Missouri, not New York.

309. Schwarzenegger v. Fred Martin Motor Co., 374 F.3d 797 (9th Cir. 2004); see also supra notes 233-35 and accompanying text.

310. 130 F.3d 414 (9th Cir. 1997).

311. Id. at 416 ; see also supra note 83 and accompanying text.

312. 223 F.3d 1082 (9th Cir. 2000); see also supra note 83 and accompanying text.

313. $223 \mathrm{~F} .3 \mathrm{~d}$ at 1085.

314. Accord Akro Corp. v. Luker, 45 F.3d 1541, 1546 (Fed. Cir. 1995); see also Amana 
The Federal Circuit has thoroughly explored the significance of cease-and-desist letters and other litigation threats in a series of decisions that, on first impression, might be thought to be inconsistent with predicating jurisdictional analysis on defendant's awareness of geographic locus of the claimed wrongful impact of its conduct. In particular, that court has repeatedly held that a patentee's sending of ceaseand-desist letters or other litigation threats to the operating headquarters of an alleged patent infringer cannot alone support the exercise of personal jurisdiction in an action by the alleged infringer in that state seeking a declaration of invalidity and/or noninfringement. ${ }^{315}$ Rather, the court has required some additional conduct, such as the patentee's own efforts to exploit the market in that state by licensing a local manufacturer or sales agent, or by entering a licensing agreement with the alleged infringer itself. $^{316}$

At first blush, this doctrine appears inconsistent with the analysis advocated here. The very wrongful impact of the litigation threat that the declaratory judgment remedy was designed to avoid is the interference with the plaintiff's right to continue to manufacture the allegedly infringing product without fear of incurring cumulating and potentially ruinous penalties. This is particularly the case if it is ultimately determined that the plaintiff has willfully infringed the defendant's patent, incurring liability for treble damages and attorneys' fees. ${ }^{317}$ This is the harm that the defendant's threat, directed specifically into the forum, has created and that the declaratory judgment remedy is designed to prevent. Thus, the defendant's cease-and-desist letter is the instrument of the very harm that is the subject of the lawsuit, and the geographic scope of its impact not only should have been, but was in fact known by the defendant. In the usual case, the very ground for a declaration of rights is that the defendant has improperly attempted to expand the scope of his patent rights by preventing lawful activities in the plaintiff's home state. ${ }^{318}$

Refrigeration, Inc. v. Quadlux, Inc., 172 F.3d 852, 857 (Fed. Cir. 1999).

315. See, e.g., Electronics for Imaging, Inc. v. Coyle, 340 F.3d 1344, 1350-51 (Fed. Cir. 2003); Hildebrand v. Steck Mfg. Co., 279 F.3d 1351, 1356 (Fed. Cir. 2002) (holding that defendant's letters warning infringement and follow-up calls regarding the letters did not support an exercise of personal jurisdiction); Inamed Corp. v. Kuzmak, 249 F.3d 1356, 1361 (Fed. Cir. 2001); Red Wing Shoe Co. v. Hockerson-Halberstadt, Inc., 148 F.3d 1355, 1360 (Fed. Cir. 1998); Genetic Implant Sys., Inc. v. Core-Vent Corp., 123 F.3d 1455, 1458 (Fed. Cir. 1997) (pointing out that the Federal Circuit has held "that sending infringement letters, without more activity in a forum state, is not sufficient to satisfy the requirements of due process"); Akro Corp., 45 F.3d at 1548, 1549; see also Cascade Corp. v. Hiab-Foco AB, 619 F.2d 36, 36-38 (9th Cir. 1980) (affirming denial of personal jurisdiction based on a letter by Swedish defendant alleging that Oregon plaintiff was infringing the defendant's patent); Lawrence D. Graham, The Personal Jurisdiction Effect of Notifications of Infringement, 78 J. PAT. \& TRADEMARK OFF. SoC'Y 858, 860-61 (1996) (stating that "[the district court] cases are legion holding that an infringement warning letter sent into a forum state, without more, does not create personal jurisdiction").

316. See, e.g., Inamed Corp., 249 F.3d at 1361; Dainippon Screen Mfg. Co. v. CFMT, Inc., 142 F.3d 1266, 1271 (Fed. Cir. 1998); Genetic Implant Sys., Inc., 123 F.3d at 1458; Akro Corp., $45 \mathrm{~F} .3 \mathrm{~d}$ at 1546 . The court has held that mere attempts to solicit a licensing agreement with the infringer, however, are insufficient "additional" conduct to support the exercise of jurisdiction. See Hildebrand, 279 F.3d at 1356; Red Wing Shoe Co., 148 F.3d at 1361.

317. See, e.g., 35 U.S.C. $§$ 284-85 (2000); Inamed Corp., 249 F.3d at 1361.

318. The Federal Circuit's rule is doubly objectionable because the additional activities that 
In more recent decisions, however, the Federal Circuit has explained its treatment of litigation threats in the declaratory judgment context in terms entirely consistent with the approach advocated here. In Red Wing Shoe Co. v. Hockerson-Halberstadt, Inc., ${ }^{319}$ the court stated that in such actions where

a patentee casts its net of cease-and-desist letters too widely and entangles some non-infringing products, a plaintiff may have little recourse other than a declaratory judgment action to disentangle its non-infringing business. In those instances, the cease-and-desist letters are the cause of the entanglement and at least partially give rise to the plaintiff's action. ${ }^{320}$

The court has justified its rule, not because the defendant has failed to satisfy the purposeful availment requirement of personal jurisdiction analysis with respect to the forum, but because in patent cases, the exercise of jurisdiction in the home forum of the declaratory judgment plaintiff does not comport with the second due process requirement that the exercise of jurisdiction be consistent with fair play and substantial justice under all of the circumstances. ${ }^{321}$

it has held to be sufficient to sustain the exercise of jurisdiction, such as the patentee's own exploitation of the patent by granting licenses or employing sales agents in the forum, logically are unrelated to the harm that they have inflicted. The harm at issue does not arise from the fact that the defendant or others are exploiting the market in the forum, but rather from the fact that the declaratory judgment plaintiff has been threatened with onerous penalties by doing so itself. The incoherence of Federal Circuit doctrine on this issue has become even more apparent in light of the insignificance of the "additional" conduct, beyond litigation threats, that it has held to be sufficient to support the exercise of jurisdiction, which has sometimes amounted to no more than "enhanced" threats and attempts to solicit the entry of a licensing agreement that the same court has held to be insufficient in other contexts. See Electronics for Imaging, Inc., 340 F.3d at 1351 (finding "other activities" such as hiring a lawyer in forum and calling and visiting plaintiff's facility in California to demonstrate patented technology and to seek a licensing agreement sufficient for personal jurisdiction).

319. 148 F.3d 1355 (Fed. Cir. 1998).

320. Id. at 1360 .

321. Id. In Silent Drive, Inc. v. Strong Industries, Inc., 326 F.3d 1194 (Fed. Cir. 2003), the Federal Circuit further explained that its "litigation threat" doctrine should be confined to the patent field. The court sustained jurisdiction over an action in an Iowa plaintiff's home forum where the plaintiff sought a declaration invalidating an injunction that the defendants had threatened to enforce there against the plaintiff to protect their trade secrets. Applying Calder, the court concluded that the defendants had "expressly aimed" their conduct at lowa because they knew that their activities would have their allegedly wrongful effects there. "Indeed, there would appear to be no other purpose in sending the injunction to Silent Drive than inhibiting Silent Drive from producing the MAXLE ...." Id. at 1204. The patent litigation threat doctrine was distinguished on the ground that

[I]n this Circuit, we have repeatedly held that the sending of infringement letters would satisfy the minimum contacts requirement of due process except for policy considerations unique to the patent context. ... The patent system has national application. If infringement letters created jurisdiction, the patentee could be haled into court anywhere the letters were sent. No such countervailing policy exists with regard to state court injunctions, which are designed to operate primarily in the [rendering] forum.

Id. at 1206 (emphasis added). 


\section{Testing Applications}

To illustrate our approach, we return to the divided opinions in Yahoo! Inc. v. La Ligue Congre Racisme et L'Antisemitisme, ${ }^{322}$ and Pavlovich v. Superior Court, ${ }^{323}$ with which we began. ${ }^{324}$ In Yahoo!, the view of the dissent was correct. Defendants had obtained a French court order that specifically required Yahoo! to take action altering its Web server in California to prevent access by French citizens to Nazi-related materials. The defendants were clearly aware that their conduct was substantially certain to have a "powerful and potentially devastating impact" claimed to violate Yahoo!'s First Amendment rights in California. ${ }^{325}$ It was that wrongful impact that was the subject of Yahoo!'s California declaratory judgment action. The majority concluded that the court lacked jurisdiction because defendants were allegedly "within their rights" ${ }^{326}$ in bringing the French action, and therefore had not committed wrongful conduct aimed at Yahoo!. This conclusion was both incorrect and misleading. The very issue in the case was whether defendants' conduct violated plaintiff's First Amendment rights. If the order violated plaintiff's First Amendment rights, as claimed, its harmful effects were felt in California. Similarly, it was irrelevant that the French defendants had not yet elected to enforce their French judgment in the United States, because the threat of accumulating penalties for failing to comply with the judgment in itself created the forbidden First Amendment impact that plaintiff's declaratory judgment action sought to prevent.

Pavlovich presents a more difficult question. The plaintiff in Pavlovich was a California-based licensing entity created by the motion picture and DVD industries to license technology that those industries had developed to prevent unauthorized copying and playback of motion pictures reproduced on DVDs. ${ }^{327}$ The licensing entity alleged that the Texas defendant's posting of source code on defendant's passive Web site should be enjoined as a misappropriation of the licensing entity's trade secrets. ${ }^{328}$ As previously discussed, a bare majority of the California Supreme Court rejected jurisdiction. ${ }^{329}$

If our suggested approach to issues of personal jurisdiction were adopted, the central inquiry would be whether the defendant was aware, or should have been aware, that the impact of his deliberate posting of the disputed technology on his Web site asserted by the plaintiff to be wrongful was substantially certain to occur in Califormia. Viewed in this light, the majority could be argued to have reached the correct result, although the matter is not free from doubt. To the extent the plaintiff's misappropriation claim was interpreted as seeking to prevent the defendant from misappropriating the licensor's property interest in the exclusive use and enjoyment of its trade secret technology, jurisdiction in California should have been sustained only if

322. 379 F.3d 1120 (9th Cir. 2004).

323. 58 P.3d 2 (2002).

324. See supra notes 2 and 5 and accompanying text.

325. Yahoo! Inc., 379 F.3d at 1134.

326. Id. at $1125-26$.

327. Pavlovich, 58 P.3d at 2; see also supra note 2 and accompanying text.

328. Pavlovich, 58 P.3d at 2.

329. Id. 
the property itself was located there. As previously discussed, in cases involving intangible property, this would suggest that the defendant's awareness that the principal place of business of the property's owner (in this case, the licensor) was in California would be required-a requirement not satisfied in Pavlovich. ${ }^{330}$

If the misappropriation claim were viewed more broadly as seeking to protect the interest of the motion picture and DVD industries in preventing unauthorized playback and copying of copyrighted motion pictures, the case for the assertion of personal jurisdiction also would be doubtful, but not precisely for the reasons asserted by the majority. The fact that the claims of a licensor for misappropriation of its trade secrets were at issue rather than those of motion picture producers or licensees for unlawful copying and playback ${ }^{331}$ should not have been determinative, because jurisdictional analysis should not require knowledge of the precise identity of the particular plaintiff that might assert claims arising out of a defendant's contacts with the state. ${ }^{332}$ Moreover, the injuries that might have been asserted by the motion picture and DVD industries were the logical corollaries of the injuries asserted by their licensing agent to its trade secret technology. Any damage to the value of the technology was entirely derivative from ultimate injury to the interests of those who used it to protect their rights to reproduce and play copyrighted motion pictures. Indeed, the technology at issue had been jointly developed by the motion picture and DVD industries, which had created the plaintiff as their licensing agent. ${ }^{333}$

Nevertheless, a requirement that the defendant know or should be on notice that the impact of his actions providing the basis for the plaintiff's suit was substantially certain to result in the forum state might lead to the same result for other reasons. In particular, there was no evidence that any California user had ever accessed the defendant's Web site, let alone that any had used the plaintiff's technology to illegally playback or reproduce copyrighted motion pictures. ${ }^{334}$ Even if there had been, the result would have been caused, not simply by the decision of such consumers to access the defendant's Web site, but by their additional, unilateral decision to engage in the unlawful conduct at issue. A proximate cause-based analysis to questions of intervening cause might well relieve the defendant of geographic responsibility for foreseeable harms that were the result of the independently unlawful decisions of third parties. $^{335}$

Perhaps the result would have been different if the record had shown widespread access followed by unauthorized playback and copying in California, of which the defendant had been placed on fair notice. In such circumstances, the defendant could no longer claim that he neither was nor should have been aware of the effects of his conduct in California, or that the actions of third parties were not the normal, expected, and foreseeable consequences of its actions. But that was not the case before the court. That is not to say that the correct result in Pavlovich was obvious. It was not, as evidenced by the close division of the court and the strong arguments advanced on both sides.

330. Id.

331. See id. at 10-13.

332. See supra Part III.C.1.

333. Pavlovich, 58 P.3d at 14 (Baxter, J., dissenting).

334. See id. at 12.

335. See supra Part III.C.3. 


\section{CONCLUSION}

It is time for the Supreme Court to revisit the subject of personal jurisdiction and minimum contacts analysis for the purpose of clarifying the meaning and relationship of its purposeful availment and express aiming tests. The Court also should provide much-needed guidance on the application of jurisdictional analysis in the modern context of wrongful conduct having potentially widespread effects caused by the transmission of information over the Internet or by other means.

We suggest that the Court should adopt a unified approach to personal jurisdiction analysis which turns primarily on whether the defendant objectively should be held to be on notice that his conduct was substantially certain to have the impact claimed by the plaintiff to be wrongful in the forum state. If so, jurisdiction would be sustained in an action based on that harm when it ensued unless the defendant could demonstrate that he should be relieved of geographic responsibility for the consequences of his actions under a proximate cause-like analysis, or that the exercise of jurisdiction would be unreasonable when balancing the factors that the Supreme Court has identified as bearing on that inquiry.

No single test for personal jurisdiction in cases involving widespread informational wrongs and intangible injuries will make difficult decisions easy or reduce questions of personal jurisdiction to a formula. However, the suggested approach at least removes the focus from elusive and ambiguous questions of purpose or intent. It adheres closely to the ultimate issue of personal jurisdiction identified by the Supreme Court, which is whether the defendant reasonably should anticipate being haled into court in the forum state as a result of the effects of his actions there. It also applies to all types of cases, whether they involve invasions of tangible or intangible interests protected by statute or by the common law, and whether they involve traditional harms committed by traditional means or informational injuries committed by means of the omnipresent Internet. 